\title{
ASSOCIAÇÃO ENTRE FATORES QUÍMICOS DE CULTIVARES \\ DE ARROZ E Oryzophagus oryzae (COSTA LIMA) \\ (COLEOPTERA: CURCULIONIDAE)
}

\section{JAIRO JOÃO CARBONARI}

Engenheiro Agrônomo

Orientador: Prof. Dr. JOSÉ DJAIR VENDRAMIM

Tese apresentada à Escola Superior de Agricultura "Luiz de Queiroz", Universidade de São Paulo, para obtenção do título de Doutor em Ciências, Área de Concentração: Entomologia.

PIRACICABA

Estado de São Paulo - Brasil

Outubro - 2000 


\title{
Dados Internacionais de Catalogação na Publicaçāo (CIP) DIVISĀO DE BIBLIOTECA E DOCUMENTAÇĀO - Campus "Luiz de Oueiroz"/USP
}

\author{
Carbonari, Jairo João \\ Associação entre fatores químicos de cultivares de arroz e Oryzophagus oryzae (Costa \\ Lima) (Coleoptera : Curculionidae) / Jairo João Carbonari. - - Piracicaba, 2000. \\ 90 p. : il. \\ Tese (doutorado) - Escola Superior de Agricultura Luiz de Queiroz, 2000. \\ Bibliografia.
}

1. Arroz 2. Elemento químico 3. Inseto-nocivo 4. Gorgulho-aquático 5. Resistência ao inseto I. Título

CDD 633.18 
Aos meus pais,

Ermes e Odila

$\&$

Aos meus irmãos,

Maria, Plinio, Bernardete, Dolores, Elton, Helena,

Edson, Ana e Fernanda,

\section{Dedico}

À minha namorada,

Luciane, 


\section{AGRADECIMENTOS}

- À Escola Superior de Agricultura "Luiz de Queiroz", da Universidade de São Paulo (ESALQ/USP), pela oportunidade de realizar o Curso de Pós-Graduação.

- À Empresa Brasileira de Pesquisa Agropecuária (Embrapa), Centro de Pesquisa Agropecuária de Clima Temperado (CPACT), pela oportunidade concedida para execução do trabalho.

- À Coordenadoria de Aperfeiçoamento de Pessoal de Nível Superior (CAPES), pela concessão da bolsa de estudo.

- Ao Dr. José Djair Vendramim, Professor do Departamento de Entomologia, Fitopatologia e Zoologia Agrícola da ESALQ/USP, pela orientação, amizade e constante apoio durante a realização do Curso de Pós-Graduação.

- Ao Dr. José Francisco da Silva Martins, Pesquisador da Embrapa Clima Temperado, pelo incentivo, apoio, confiança, amizade, sugestões e oportunidade para realização de mais este trabalho.

- Aos amigos, Marcos Botton, Pesquisador da Embrapa Uva e Vinho e Mauro Silveira Garcia, Professor do Departamento de Fitossanidade da FAEM/UFPel, pelo constante apoio, amizade e sujestões.

- Aos estagiários da Embrapa Clima Temperado, Eng. Agr. Pós Graduando Uemerson da Silva Cunha e Acadêmico de Agronomia da Universidade Federal de Pelotas Ederson Adriano Pan, pelo auxílio, amizade, companheirismo, durante todas as etapas dos trabalhos. 
- Aos professores e funcionários do Setor de Entomologia da ESALQ/USP, pela acolhida amiga, atenção dispensada e valiosos ensinamentos.

- Aos colegas do Setor de Entomologia da ESALQ/USP, pela amizade, companheirismo e agradável convívio durante a realização do Curso.

- Às bibliotecárias Eliana Maria Garcia Sabino e Kátia Maria de Andrade Ferraz, pela revisão das referências bibliográficas, atenção e amizade.

- Ao funcionário da Embrapa Clima Temperado, Elton Rogério Fonseca, pela inestimável colaboração e dedicação na condução dos experimentos.

- A todos que, direta ou indiretamente, contribuíram para a realização deste trabalho. 


\section{SUMÁRIO}

Página

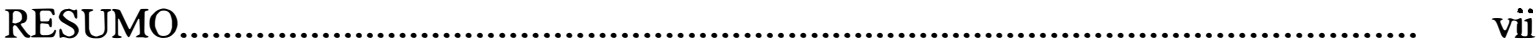

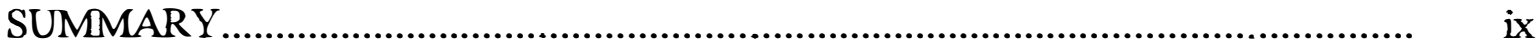

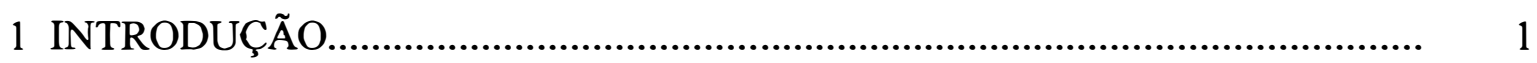

2 REVISÃO DE LITERATURA..................................................................... 4

2.1 Gorgulhos aquáticos na cultura do arroz................................................. 4

2.1.1 Aspectos bioecológicos e comportamentais.......................................... 4

2.1.2 Resistência de arroz ao inseto.............................................................. 6

2.2 Mecanismos de resistência da planta de arroz............................................... 8

2.2.1 Fatores morfológicos.............................................................................. 9

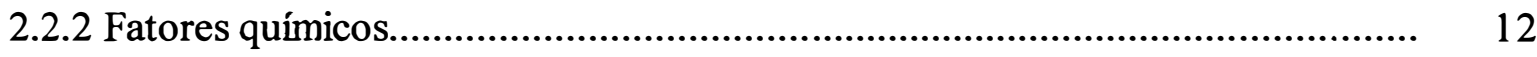

2.3 Dinâmica de elementos químicos na planta.................................................... 18

2.3.1 Nitrogênio..................................................................................... 18

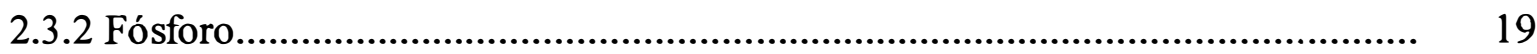

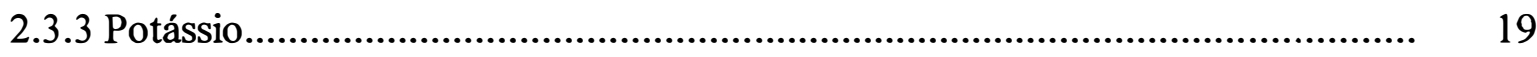

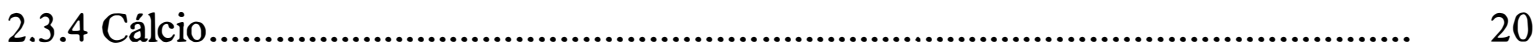

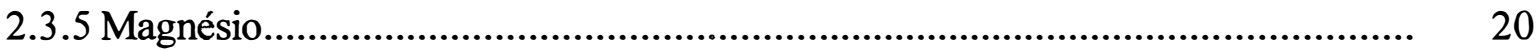

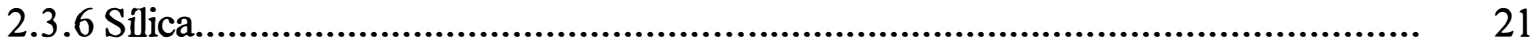

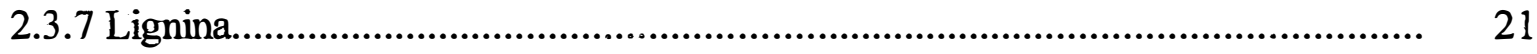

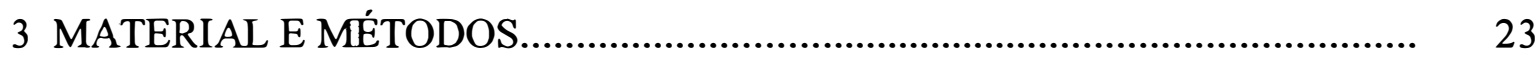

3.1 Local........................................................................................ 23

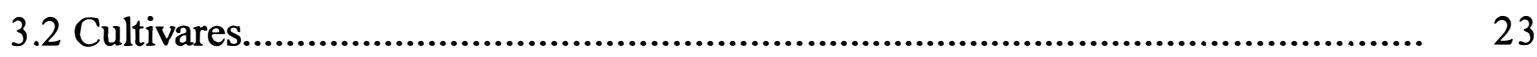

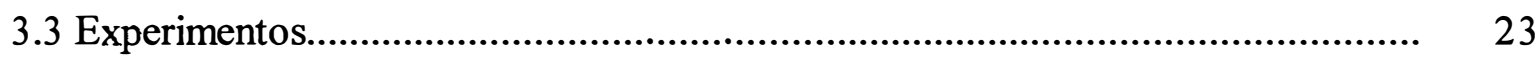

3.3.1 Com chance de escolha....................................................................... 24

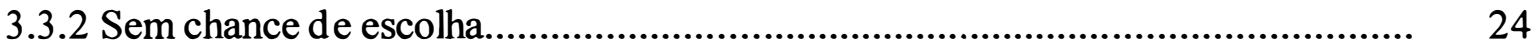

3.4 Manejo do solo e práticas culturais...................................................... 27

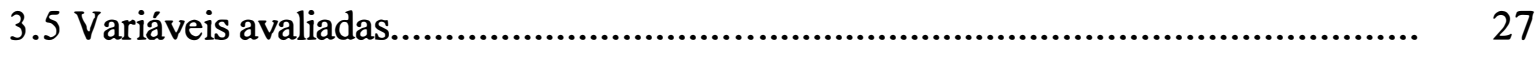

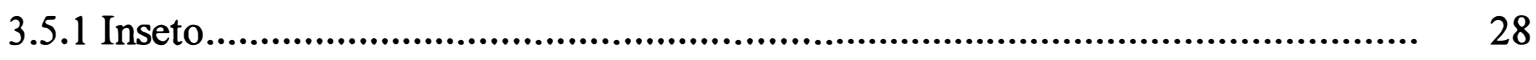

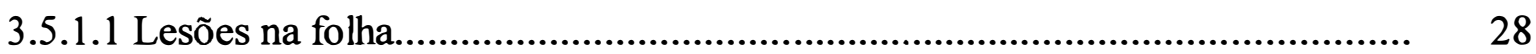


3.5.1.2 Número de ovos......................................................................... 28

3.5.1.3 Número de larvas.............................................................................. 28

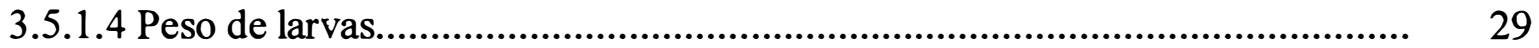

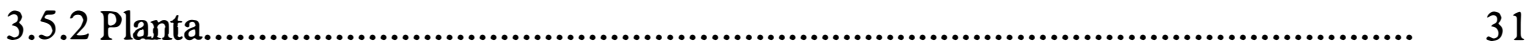

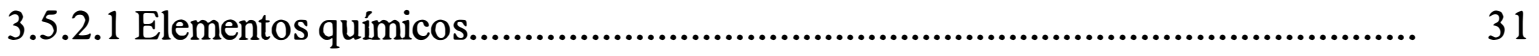

3.5.2.2 Produção de grãos................................................................................ 31

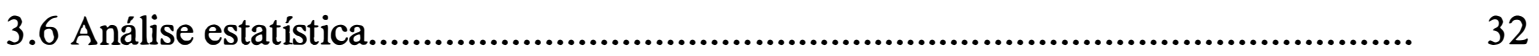

4 RESULTADOS E DISCUSSÃO................................................................ 33

4.1 Efeito de elementos químicos de cultivares de arroz sobre Oryzophagus oryzae. 33

4.1. Fase adulta................................................................................. 33

4.1.1 Alimentação ........................................................................................... 33

4.1.2 Oviposição........................................................................................... 37

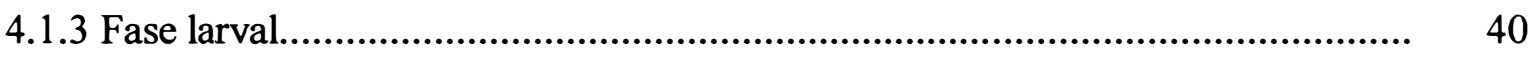

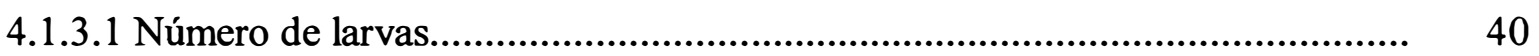

4.1.3.2 Peso de larvas................................................................................... 43

4.2 Efeito de $O$. oryae sobre cultivares de arroz....................................................... 48

4.2.1 Elementos químicos da planta................................................................... 48

4.2.1.1 Nitrogênio ........................................................................................ 49

4.2.1.2 Fósforo

4.2.1.3 Potássio ......................................................................................... 55

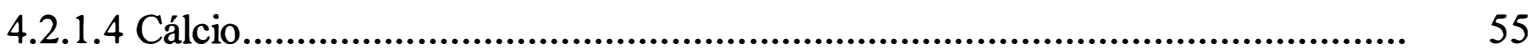

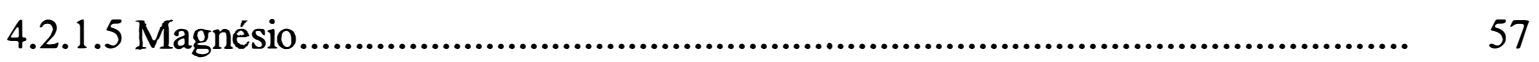

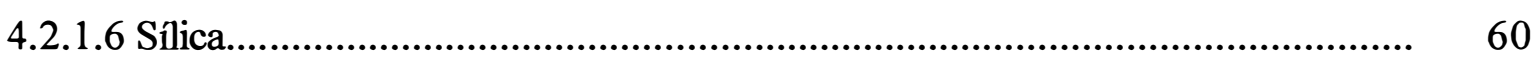

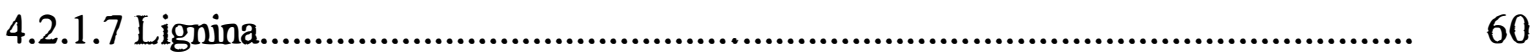

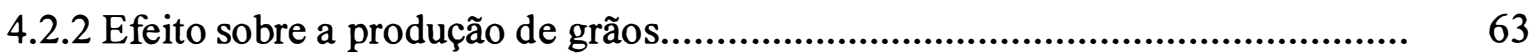

4.3 Considerações finais....................................................................................... 65

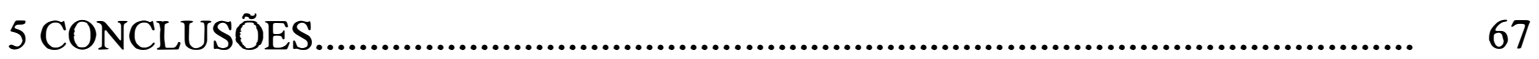

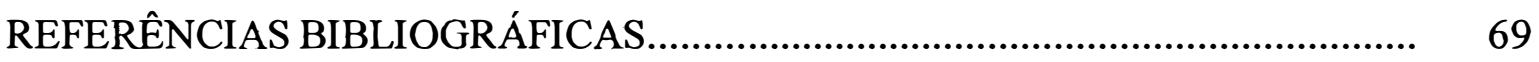




\title{
ASSOCIAÇÃO ENTRE FATORES QUÍMICOS DE CULTIVARES DE ARROZ E Oryzophagus oryzae (COSTA LIMA) (COLEOPTERA: CURCULIONIDAE)
}

\author{
Autor: JAIRO JOÃO CARBONARI \\ Orientador: Prof. Dr. JOSÉ DJAIR VENDRAMIM
}

\section{RESUMO}

A associação entre elementos químicos de plantas de arroz e a população de Oryzophagus oryzae foi avaliada nas cultivares BR IRGA 410, BRS FIRMEZA, Dawn e BRS ATALANTA, diferenciadas quanto ao ciclo de desenvolvimento fenológico e grau de resistência ao inseto, em experimentos a campo, com e sem chance de escolha de hospedeiro, nos anos agrícolas 1997/98 e 1998/99, na Embrapa Clima Temperado, Pelotas, RS. Relativo ao inseto foram avaliados número de folhas lesionadas, número de ovos e número e peso de larvas. Relativo à planta, em três épocas distintas, foram avaliados os teores de nitrogênio, fósforo, potássio, cálcio, magnésio, sílica e lignina, na parte aérea e raízes. A alimentação de adultos de $O$. oryzae foi estimulada pelos teores de nitrogênio e potássio, e inibida pelo teor de silica, presentes na parte aérea das plantas. $\mathrm{O}$ oviposição foi estimulada pelos teores de nitrogênio, cálcio e potássio, e inibida pelo teor de sílica. A população larval do inseto aumentou com o incremento no teor de fósforo e diminuiu com o aumento do teor de sílica, nas raízes das plantas. $\mathrm{O}$ desenvolvimento larval foi estimulado pelo teor de potássio e inibido pelo teor de sílica. $\mathrm{O}$ dano às raízes, provocado por larvas de $O$. oryzae, reduziu o teor de nitrogênio, fósforo, potássio, cálcio e magnésio, e aumentou o teor de lignina nas plantas. A cultivar Dawn foi a única a recuperar o teor de nitrogênio, fósforo e sílica, nas raízes da planta, por apresentar menor número de larvas e maior ciclo de desenvolvimento. Ao contrário dos demais elementos 
químicos avaliados, o teor de lignina foi maior nas plantas infestadas pelo inseto, devido à intensificação da lignificação após o dano às raízes provocado pelas larvas do mesmo. $\mathrm{O}$ ataque de larvas de $O$. oryzae às raízes das cultivares avaliadas provoca redução do teor de nitrogênio, fósforo, potássio, cálcio e magnésio, tanto na parte aérea como nas raízes, e consequentemente perda na produção de grãos. 


\title{
ASSOCIATION BETWEEN CHEMICAL FACTORS OF RICE CULTIVARS AND Oryzophagus oryzae (COSTA LIMA) (COLEOPTERA: CURCULIONDAE)
}

\author{
Author: JAIRO JOÃO CARBONARI \\ Adviser: Prof. Dr. JOSÉ DJAIR VENDRAMIM
}

\section{SUMMARY}

The association between chemical elements of rice plants and the population of Oryzophagus oryzae was evaluated in the cultivars BR IRGA 410, BRS FIRMEZA, Dawn and BRS ATALANTA, differentiated by the phenological development cycle and resistance degree to the insect, under field experiments, with and without chance of host choice, during 1997/98 and 1998/99 crop seasons, at Embrapa Clima Temperado, Pelotas, RS. Relative to the insect, the number of damaged leaves, number of eggs and number and weight of larvae were evaluated. Relative to the plant, the content of nitrogen, phosphorus, potassium, calcium, magnesium, silica and lignin were evaluated, in the leaves and roots in three different rice growth stage. The adults of $O$. oryzae feeding was stimulated by the content of nitrogen and potassium, and inhibited by the silica content present in the foliage of the plant. The oviposition was stimulated by the content of nitrogen, calcium and potassium, and inhibited by the silica content. The larval population of the insect increased with the increment in the phosphorus content and decreased with the increase of the silica content, in the roots of the plants. The larval development was stimulated by the potassium content and inhibited by the silica content. The damage to the roots provoked by larvae of $O$. oryzae reduced the content of nitrogen, phosphorus, potassium, calcium and magnesium, and increased the lignin 
content in the plants. The cultivar Dawn was the only one to recover the content of nitrogen, phosphorus and silica, in the roots of the plant, because the presence of the smallest number of larvae and the largest development cycle. Unlike the other appraised chemical elements, the lignin content was larger in the plants infested by the insect, due to the intensification of the lignification after the damage to the roots provoked by the larvae. The attack of larvae of $O$. oryzae to the roots of the evaluated rice cultivars caused reduction of the content of nitrogen, phosphorus, potassium, calcium and magnesium, in the leaves and in the roots, and consequently loss in the yield. 


\section{INTRODUÇÃO}

No agronegócio brasileiro e mais precisamente do Rio Grande do Sul, a cultura do arroz assume importância sócioeconômica destacada. A participação generalizada deste cereal na dieta básica da população de todas as regiões e classes sociais do Brasil é atribuída principalmente à relação custo e valor energético. Aproximadamente $60 \%$ da produção nacional advêm de lavouras irrigadas por inundação, denominado arroz irrigado, concentradas em cerca de um milhão de hectares do Rio Grande do Sul e Santa Catarina.

A lavoura orizícola irrigada do Brasil é danificada por diversas espécies de insetos, destacando-se Oryzophagus oryzae (Costa Lima, 1936) pelos consideráveis danos causados às plantas (Camargo, 1991; Ferreira \& Martins, 1984; Martins et al., 1995 e Oliveira, 1987). O inseto, conhecido na fase adulta por gorgulho aquático, alimenta-se de folhas e oviposita nas partes submersas das plantas de arroz (Moreira, 1996 e Prando, 1999). As larvas, denominadas bicheira-da-raiz, ao alimentarem-se do sistema radicular, afetam o crescimento e desenvolvimento das plantas, em lavouras inundadas (Martins \& Ferreira, 1980).

No Rio Grande do Sul, onde a cultura do arroz é predominantemente implantada pelo sistema de cultivo convencional, o inseto, que atacava apenas áreas localizadas da lavoura (Martins \& Ferreira, 1980), passou, nos últimos anos, a ocorrer de forma generalizada em quase toda a extensão dos arrozais (Martins, 1990 e Oliveira, 1993), em conseqüência das constantes modificações tecnológicas nos diferentes sistemas de cultivo (Martins \& Botton, 1996). 
Em aproximadamente $25 \%$ da área de arroz cultivada no RS, ocorrem graus diferenciados de infestação de O. oryzae (Martins et al., 1988), causando perdas anuais de produção estimadas em 10 a 30\% (Botton et al., 1996 e Martins, 1990). No sistema de cultivo pré-germinado, utilizado principalmente em Santa Catanina, as perdas são ainda maiores, pois o inseto na fase adulta pode causar danos sensíveis às plântulas, que somado ao das larvas, torna-o potencialmente mais prejudicial (Lima, 1951), ocasionando perdas aproximadas de 30\% (Prando \& Pegoraro, 1993).

Práticas culturais como limpeza dos canais de irrigação, eliminação de restos de cultura e aplainamento do solo são eficientes na redução da população de $O$. oryzae (Martins \& Botton, 1996 e Martins \& Ferreira, 1980). Porém, é freqüente a utilização de inseticidas químicos para controle do inseto, através do tratamento de sementes (Carbonari et al., 1995, 1997, 1998; Martins et al., 1996b e Oliveira, 1999a), em pulverização foliar, logo após a inundação do arrozal (Cruz, 1992; Martins et al., 1996a, 1997b, 1999 e Oliveira, 1994, 1999b) e com granulados distribuídos em cobertura na água de irrigação (Martins et al., 1993, 1977a e Oliveira, 1994).

$\mathrm{Na}$ busca da auto-sustentabilidade do sistema produtivo, visando principalmente à redução dos custos operacionais e riscos de contaminação do agroecossistema, o uso de cultivares resistentes a $O$. oryzae é considerado alternativa promissora para a redução de danos à cultura do arroz irrigado (Carbonari, 1996 e Martins et al., 1993, 1997a, 1998). A obtenção de cultivares de arroz resistentes a $O$. oryzae e com elevado potencial produtivo é possível, visto os resultados promissores já obtidos com esta espécie (Martins \& Terres 1995) e com Lissorhoptrus oryzophilus Kuschel nos EUA (N'Guessan et al., 1994a, 1994b; N'Guessan \& Quisenberry, 1994 e Smith \& Robinson, 1982). Resistência dos tipos antixenose, antibiose e tolerância a gorgulhos aquáticos foi encontrada em plantas de arroz (Bowling, 1980; Carbonari, 1996 e Martins \& Terres, 1989).

No estudo da resistência de arroz irrigado a $O$. oryzae, ações de pesquisa têm sido priorizadas na fase larval do inseto (Martins \& Ferreira, 1980), devido aos maiores danos provocados às plantas, nesta fase de desenvolvimento. Porém, visto as 
recentes elucidações do hábito de alimentação e oviposição e da intensificação dos danos causados pelos adultos no sistema pré-germinado (Moreira, 1996; Moreira et al., 1996 e Prando, 1999), é procedente que esta fase do inseto também seja devidamente considerada. Ademais, sendo a seleção hospedeira realizada pelos adultos, no momento da irrigação por inundação, caracteres presentes na parte aérea da planta, podem exercer efeitos adversos à infestação do inseto.

Os recentes e constantes avanços da biotecnologia, como cultura de tecidos e anteras, transgenia, entre outros, somados às técnicas convencionais do melhoramento genético de plantas, permitem com maior facilidade, a detecção, manipulação e transferência de genes responsáveis por caracteres potenciais de resistência a insetos-praga, intensificando e otimizando os trabalhos dos programas de melhoramento genético.

Este trabalho tem por objetivo associar caracteres químicos da parte aérea e do sistema radicular de plantas de arroz irrigado, ao ataque de $O$. oryzae; avaliar os efeitos destes sobre a alimentação de adultos, oviposição, sobrevivência e desenvolvimento larval, em cultivares de arroz diferenciadas quanto ao grau de resistência ao inseto e ciclo fenológico da planta e determinar os efeitos do inseto sobre o teor de elementos químicos e produção das plantas. 


\section{REVISÃO DE LITERATURA}

\subsection{Gorgulhos aquáticos na cultura do arroz}

\subsubsection{Aspectos bioecológicos e comportamentais}

As espécies de gorgulhos aquáticos que atacam a cultura do arroz irrigado pertencem à familia Curculionidae e aos gêneros Helodytes Kuschel, 1952; Lissorhoptrus Leconte, 1876 e Oryzophagus Kuschel, 1952 (Camargo et al., 1990 e Kuschel, 1951, 1956). Os adultos medem de 2,7 a 5,6 mm de comprimento e 1,5 a 2,6 $\mathrm{mm}$ de largura, sendo as fềmeas maiores que os machos. Além do maior tamanho, a fềmea de Oryzophagus oryzae (Costa Lima, 1936) possui uma leve depressão na parte posterior do metaesterno e no primeiro e segundo esternos abdominais, acentuando o dimorfismo sexual (Prando, 1999).

$\mathrm{Na}$ entressafra da cultura do arroz, período compreendido entre os meses de abril e outubro, no Sul do Brasil, os adultos de $O$. oryzae permanecem em diapausa (hibernação) em restos culturais, diversas espécies de gramíneas e ciperáceas adjacentes às lavouras, solo e palhada de bosques nativos, bambu, eucalipto e pinheiro (Camargo et al., 1990; Link \& Costa, 1991; Mielitz et al., 1996; Oliveira, 1998 e Pugliese, 1956).

Com a implantação de novos cultivos, os adultos imigram para a lavoura principalmente através da água de irrigação ou vôo (Camargo, 1991). As primeiras lavouras de arroz, semeadas dentro do período normal de cultivo, são as mais infestadas, por receberem a maior parte dos insetos hibernantes (Martins, 1976 e Martins \& Botton, 1996). 
Inicialmente, ao alimentarem-se através da raspagem do parênquima foliar da planta de arroz, os adultos provocam a formação de lesões longitudinais de aproximadamente 1,5 mm de largura e 1,5 a 3,0 cm de comprimento. Após acasalaremse, ovipositam endofiticamente em partes submersas das lacunas do parênquima aerífero das bainhas foliares, preferencialmente em plantas jovens localizadas nas partes mais profundas da lavoura com maior lâmina d'água (Martins, 1979). Os ovos, de coloração esbranquiçada, medem $0,85 \mathrm{~mm}$ de comprimento e $0,23 \mathrm{~mm}$ de diâmetro e têm período de incubação de aproximadamente 6 dias a $25^{\circ} \mathrm{C}$. Logo após a eclosão, as larvas alimentam-se do tecido vegetal próximo ao local da postura, destruindo as membranas divisórias das lacunas do aerênquima, por um período de aproximadamente 24 horas. Através de um orificio circular e por movimentos ondulatórios, a larva sai da bainha foliar, migrando para as raízes (Bowling, 1973, 1980; Grigarick \& Beards, 1965; Moreira, 1996; Moreira et al., 1996 e Prando, 1999). No último estádio larval, aproximadamente 25 dias após a eclosão, as larvas confeccionam um pequeno casulo de argila e material vegetal, aderido a uma raiz jovem, pupando no seu interior, onde permanecem por cerca de 10 dias, até a emergência dos adultos (Martins \& Ferreira, 1980 e Prando, 1999).

$\mathrm{O}$ inseto apresenta no mínimo duas gerações durante o período de desenvolvimento da cultura. A primeira é considerada de maior importância, pois ao atacar plantas com o sistema radicular pouco desenvolvido, provoca danos mais severos. A segunda geração ocorre sobre plantas com raízes mais desenvolvidas, as quais suportam maior ataque do inseto (Pugliese, 1956).

No final do ciclo da cultura, os adultos entram em diapausa, caracterizada pela degeneração dos músculos de vôo (Matsui et al., 1983 e Muda et al., 1981), atrofia dos órgãos reprodutivos e acúmulo de corpos gordurosos nas cavidades abdominais (Matsui et al., 1983; Nilake, 1977 e Redaelli et al., 1995). A imigração para as novas lavouras ocorre com a elevação da temperatura, aumento da fotofase e início da irrigação por inundação (Camargo, 1991; Morgan et al., 1984 e Muege et al., 1996). 


\subsubsection{Resistência de arroz ao inseto}

A resistência de arroz a gorgulhos aquáticos inclui os tipos antixenose, antibiose e tolerância (Bowling, 1980 e Martins \& Terres, 1989). De acordo com Maxwell \& Jennings (1980), a antixenose e a antibiose estariam associadas a fatores fisicos e químicos da planta de arroz, os quais reduziriam a oviposição do gorgulho e provocariam a morte de larvas na fase inicial de crescimento. A tolerância manifesta-se pela recuperação do sistema radicular após o corte provocado pelas larvas.

Os estudos da resistência de plantas de arroz a gorgulhos aquáticos têm sido desenvolvidos principalmente nos EUA, através de programas de melhoramento genético, com objetivo de obter cultivares resistentes a Lissorhoptrus oryzophilus (Bowling, 1980 e N'Guessan \& Quisenberry, 1994). Bowling (1963) associou a redução da produção de grãos em cultivares de arroz, comparando parcelas protegidas e desprotegidas do ataque do inseto e a população larval de L. oryzophilus, evidenciando resistência do tipo tolerância. Em trabalhos de resistência de arroz a $L$. oryzophilus,

cultivares de origem filipina apresentaram significativamente menor infestação que a suscetível 'Saturn', utilizada como padrão de comparação. A resistência destas cultivares foi detectada pelo menor desenvolvimento larval e atribuída à presença de substâncias inibidoras de crescimento (Smith \& Robinson, 1982).

N'Guessan \& Quisenberry (1994), através da população larval, dano e recuperação do sistema radicular, altura de plantas e produção de grãos, avaliaram o grau de resistência de genótipos de arroz a $L$. oryzophilus. Elevados níveis de tolerância foram observados em determinadas linhagens, pela capacidade de recuperação do sistema radicular danificado por larvas e elevada produção de grãos de plantas altamente infestadas. Resistência do tipo antixenose foi expressa por cultivares que apresentaram níveis moderados de infestação larval, significativamente menores que a testemunha suscetível.

Genótipos de arroz provenientes de cultura de tecidos e de anteras submetidos ao ataque de L. oryzophilus apresentaram resistência do tipo tolerância e 
antixenose (N'Guessan et al., 1994a, 1994b). Tsuzuki et al. (1984) e Nagata (1990) encontraram genótipos de arroz tolerantes a $L$. oryzophilus, em programas de melhoramento genético da cultura no Japão.

No Brasil, mecanismos de resistência de genótipos de arroz a $O$. oryzae são avaliados seguindo metodologia semelhante à proposta por Heinrichs et al. (1985) para $L$. oryzophilus. A maior parte dos trabalhos visando a resistência de arroz a $O$. oryzae são conduzidos a campo, sob infestação natural do inseto (Botton, 1994; Cunha et al., 1999; Him Him, 1980; Martins \& Terres, 1989, 1991, 1995 e Martins et al., 1997c).

Cultivares de arroz submetidas a infestação de $O$. oryzae tiveram o grau de resistência avaliado pelo número e tamanho de larvas, volume de raízes e produção de grãos de plantas. As cultivares Dawn, EEA 404 e RS 16-516-1-1-1T apresentaram menor população larval, enquanto 'BR-IRGA 409', 'BR-IRGA 410' e 'Formosa' foram as mais atacadas pelo inseto. A época ideal para o levantamento da população larval foi aos 30 dias após a irrigação definitiva da lavoura. As demais variáveis avaliadas não se mostraram eficientes na discriminação de genótipos resistentes a $O$. oryzae (Him Him, 1980). Diferenças significativas foram constatadas em genótipos de arroz irrigado quanto ao número de folhas atacadas por adultos de $O$. oryzae, número de larvas nas raízes, tamanho de larvas e redução na produção de grãos (Martins \& Terres, 1989). O grau de resistência a $O$. oryzae das principais cultivares de arroz irrigado utilizadas nas lavouras do Rio Grande do Sul foi determinado por Martins \& Terres (1995), sendo 'BR-IRGA 410' e 'BR-IRGA 413' consideradas resistentes e 'BR-IRGA 414', altamente suscetível.

As variáveis número de folhas lesionadas pelo inseto adulto, número e tamanho de larvas por amostra e percentual de redução na produção de grãos, foram usadas para avaliar a resistência de cultivares e genótipos de arroz a $O$. oryzae. Correlações entre o número de larvas por amostra e a percentagem de redução na produção de grãos foram estabelecidas. Baixos valores para as variáveis número de larvas e redução de produção foram associados à antixenose para adultos e antibiose ou antixenose para larvas, enquanto que a tolerância foi verificada através de baixos índices de redução de produção na presença de elevado número de larvas. A cultivar BR-IRGA 
413 apresentou resistência do tipo tolerância, enquanto 'Dawn' do tipo antixenose e antibiose (Martins \& Terres, 1995).

Botton (1994) avaliou a suscetibilidade de genótipos de arroz a $O$. oryzae, através das variáveis número de larvas por amostra, tamanho de larvas e índice de recuperação do sistema radicular. Os genótipos CL 26-1-1-1, IRGA 234-21-5-6-1 e IRGA 304-6-1-A apresentaram maior recuperação do sistema radicular após o ataque das larvas. Raizes com maior diâmetro apresentaram índice de recuperação mais elevado.

A tolerância de plantas de arroz a $O$. oryzae, em hipótese, é mais fácil de ser encontrada em genótipos de ciclo médio e longo, devido a maior duração da fase vegetativa, pois estes diferem na capacidade de recuperação do sistema radicular danificado pelas larvas (Carbonari, 1996; Carbonari et al., 2000; Martins \& Terres, 1985, 1989 e Martins et al., 1997b). Neste sentido, as cultivares BR-IRGA 410 e Dawn, de ciclo médio, apresentaram maior capacidade de recuperação do sistema radicular danificado e menores perdas de produção de grãos, em relação às de ciclo curto 'BRIRGA 414' e 'Bluebelle', devido ao maior período de perfilhamento após o pico populacional de $O$. oryzae, que ocorreu similarmente independente do ciclo fenológico das plantas (Carbonari et al., 2000).

Através do índice de infestação larval de $O$. oryzae, genótipos de arroz são selecionados quanto à resistência dos tipos antixenose e antibiose, e posteriormente incluídos em avaliações do tipo tolerância. Principalmente genótipos altamente precoces, que apresentam reduzidos índices de infestação larval e, por isso, com relevante interesse para programas de melhoramento genético da cultura, são utilizados em hibridações, visando incorporar características de resistência ao inseto, nas cultivares em desenvolvimento (Cunha et al., 1999 e Martins \& Terres, 1989).

\subsection{Mecanismos de resistência da planta de arroz}

Embora haja considerável volume de trabalhos sobre resistência de arroz aos gorgulhos aquáticos, poucos referem-se especificamente aos fatores da planta que 
conferem esta resistência. $\mathrm{Na}$ maioria dos estudos, somente a fase larval do inseto e o sistema radicular são considerados, devido à concentração dos danos a este órgão da planta. Ademais em arroz, associações entre fatores de resistência e danos de insetos restringem-se àqueles que atacam a parte aérea da planta.

\subsubsection{Fatores morfológicos}

As plantas possuem características morfológicas próprias, muito variáveis entre espécies. Porém, as variantes morfológicas intra-específicas também são consideráveis, em função da variabilidade genética na espécie vegetal (Matsuo et al., 1997). Desta forma, muitas características, como tipo e formação da epiderme, dimensão e disposição de estruturas presentes nos diferentes órgãos da planta, atuam sobre os insetos, sendo consideradas causas morfológicas de resistência, quando estas afetam negativamente o comportamento e desenvolvimento do mesmo (Lara, 1991).

Caracteres morfológicos de plantas de arroz foram associadas a níveis de infestação das brocas-do-colmo Chilo suppressalis e Diatraea saccharalis (Martins et al., 1977c, 1989 e Patanakamjorn \& Pathak, 1967). Cultivares com folhas pilosas foram menos preferidas para oviposição em relação àquelas com folhas glabras. Também foi constatado que na maioria das cultivares resistentes, os internódios são totalmente envolvidos pelas bainhas das folhas, o que dificulta a penetração e estabelecimento das lagartas no colmo das plantas. Outras características como número e comprimento de internódios, altura de plantas e comprimento e largura da folha-bandeira estão associadas à alimentação e oviposição do inseto (Martins et al., 1977b e 1981).

Pathak et al. (1971) verificaram o efeito da pilosidade da folha sobre a oviposição de $C$. suppressalis nas cultivares TKM-6 e Rexoro. A oviposição foi, aproximadamente, $50 \%$ superior na cultivar Rexoro, suscetível e com folhas glabras, em relação a TKM-6, resistente e com folhas pilosas. Plantas de arroz com folhas glabras apresentam menor porcentagem de colmos atacados por D. saccharalis (Martins et al., 1981). 
A epiderme das plantas de arroz possui uma camada de tecido esclerenquimatoso, cuja espessura pode variar entre cultivares. Plantas que possuem esta camada mais espessa são menos infestadas por broca-do-colmo (IRRI, 1964). Patanakamjorn \& Pathak (1967) verificaram que cultivares com a superficie do colmo rugosa, são geralmente menos infestadas por $C$. suppressalis, comparadas com aquelas com a superficie lisa. Nos colmos com superficie rugosa, os feixes vasculares localizamse no interior dos tecidos lignificados. Já em colmos com superficie lisa, somente parte dos feixes entra em contato com os tecidos lignificados, ficando o restante inserido na área parenquimatosa. Desta forma, plantas com o colmo rugoso, possuem na região da hipoderme, maior área com células de parede mais espessa, conferindo assim resistência a insetos. Características da superfície da planta foram assinaladas como causa de diferenças na locomoção e alimentação de Nilaparvata lugens sobre cultivares de arroz. A cultivar IR 46, por apresentar menor densidade de tricomas, foi mais afetada pelo inseto que apresentou maior mobilidade e intensidade de alimentação (Woodhead \& Padgham, 1988). Os autores verificaram três diferentes tipos de tricomas na superfície das plantas de arroz.

O comprimento, altura e largura das diferentes partes da planta, constituem causas de resistência a determinadas espécies de insetos. Assim, Patanakamjorn \& Patthak (1967) verificaram que adultos de $C$. suppressalis apresentam preferência para ovipositar em plantas de arroz que possuem a folha-bandeira mais longa e larga. Martins et al. (1977b) constatou fato semelhante com a oviposição de $D$. saccharalis em plantas de arroz. Em condições de laboratório, a diferença foi significativa entre o número de posturas, sendo a cultivar IAC 9 a mais ovipositada. Ocorreu interação significativa entre a face da folha e as cultivares quanto à oviposição. As pilosas na face superior foram menos ovipositadas, mas não diferiram das glabras na face inferior, onde não há tricomas. A pilosidade ou um fator associado a ela exerceu um efeito negativo na oviposição. A preferência para oviposição ocorreu na metade superior de plantas da cultivar mais alta. 
Características morfológicas de plantas de arroz foram associadas com a resistência a Chilo zacconius na África (Ukwungwu \& Odebiyi, 1985). Correlações positivas foram encontradas entre porcentagem de lagartas com diâmetro do colmo e comprimento da folha-bandeira. A intensidade de colmos atacados por $D$. saccharalis foi correlacianada com a altura de plantas, número e comprimento de internódios e diâmetro interno e externo do colmo. Cultivares e linhagens pilosas foram menos infestadas que as glabras (Martins et al., 1981).

A aderência da bainha foliar no colmo de planta de arroz constitui-se em importante característica morfológica em cultivares resistentes a determinados insetos (Grigarick \& Beards, 1965; Martins et al., 1981 e Patanakamjorn \& Pathak, 1967). Cultivares de arroz resistentes às brocas-do-colmo, C. suppresalis (Patanakamjorn \& Pathak,1967) e D. saccharalis (Martins \& Pinheiro, 1981), apresentaram internódios totalmente envolvidos pelas bainhas das folhas, o que dificulta a penetração e estabelecimento das lagartas no colmo das plantas.

Grigarick \& Beards (1965) verificaram que cultivares de arroz com a lígula presa ao colmo e consequentemente com bainha aderida, são menos preferidas para oviposição pelo gorgulho-aquático Lissorhoptrus oryzophilus, visto o hábito do inseto em ovipositar entre a bainha e o colmo da planta.

A disposição da pálea e lema da casca do grão de arroz constitui causa de resistência a insetos que atacam em condições de armazenamento. Dois tipos de defeitos podem ser encontrados no grão, fenda lateral e ponta aberta (Link \& Rossetto, 1972). O ataque de Sitophilus oryzae e S. zeamais é proporcional ao número de grãos que apresentam defeitos na casca (Russell, 1968). Maior porcentagem de emergência de Sitotroga cerealella foi constatada em cultivares de arroz com freqüência elevada de grãos com casca defeituosa, quando comparados com grãos perfeitamente fechados pela casca (Link \& Rossetto, 1972).

Nunes \& Silva (1989) verificaram, em três cultivares de arroz de sequeiro, que a emergência de Sitophilus spp. foi significativamente superior naquela que apresentava maior percentual de defeitos na casca. Vendramim et al. (1989), estudando a 
sobrevivência de adultos e a reprodução de $S$. zeamais e $S$. oryzae em grãos de arroz com casca apresentando diferenciado grau de defeitos, constataram que grãos com casca integra dificultaram a sobrevivência de adultos e impediram a reprodução das duas espécies. Em grãos danificados, o número de adultos emergidos foi diretamente proporcional ao grau de defeitos na casca.

\subsubsection{Fatores químicos}

A maioria das interações de ataque, defesa e respostas ao comportamento dos insetos envolve agentes ou compostos químicos presentes na planta. Tais compostos, em função do efeito causado sobre os insetos, podem ser classificados em substâncias que afetam o comportamento e metabolismo do inseto e impropriedades nutricionais. As substâncias químicas que atuam no comportamento de insetos estão presentes em animais e vegetais, porém concentradas nestes últimos. 'Estas substâncias podem ser encontradas nas diferentes partes da planta e suas concentrações variam com a idade da mesma (Lara, 1991).

Entre os fatores químicos que interferem na relação planta de arroz com insetos, estão incluídas substâncias não nutritivas (Ishii, 1971). Algumas destas, conhecidas por aleloquímicos (Maxwell \& Jennings, 1980), são capazes de influenciar negativamente na escolha do hospedeiro e no crescimento e desenvolvimento do inseto. A substância p-metil-acetofenona foi isolada de plantas de arroz e identificada como

atraente para lagartas e adultos de $C$. suppressalis (Munakata et al., 1959). Ácidos aromáticos, benzóico e salicílico presentes em plantas de arroz, possuem a capacidade de inibir o crescimento de $C$. supressalis, porém, pequenas quantidades de extratos destas plantas estimularam o desenvolvimento das lagartas (Ishii et al., 1962).

Aminoácidos livres presentes na seiva das plantas também interferem no comportamento do inseto. Maiores concentrações de aminoácidos livres na seiva elaborada de cultivares de arroz foram associadas com a preferência alimentar de Nephotettix virescens (Auclair et al., 1982). Resultado semelhante foi constatado por 
Auclair \& Baldos (1982) ao observarem o comportamento alimentar de Sogatella furcifera sobre cultivares de arroz suscetível e resistente ao inseto. A preferência para alimentação foi associada a maiores concentrações de aminoácidos livres, significativamente superior na cultivar suscetível. Isto demonstra que na possibilidade de escolha, o inseto preferiu a planta nutricionalmente mais adequada ao seu desenvolvimento.

Compostos voláteis, ácidos e flavonóides são substâncias freqüentemente mencionadas como responsáveis pela seleção hospedeira de insetos fitófagos. Mahatheer et al. (1995), através da extração de compostos voláteis de cultivares de arroz suscetíveis e resistentes a $N$. lugens, encontraram o aldeído 3,7-dimethyl-2,6-octadienal em maior quantidade nas resistentes, sendo associado como fator de resistência ao inseto. Ácido oxálico ( $\mathrm{Li}$ et al.,1996) e flavonóides (Grayer et al., 1994) foram encontrados em cultivares resistentes de arroz, como possíveis substâncias responsáveis pela inibição da alimentação de $N$. lugens. Shigematsu et al. (1982), em cultivares de arroz suscetíveis e resistentes a $N$. lugens, correlacionaram maiores teores de asparagina com a estimulação e $\beta$-sisterol com a inibição da alimentação.

Muitas substâncias presentes nas plantas podem apresentar efeitos de antibiose provocando alongamento do período de desenvolvimento, mortalidade de formas jovens, mortalidade durante a metamorfose, redução do tamanho e peso, redução da fecundidade, alteração da proporção sexual e alteração na longevidade. Substâncias tóxicas em plantas de arroz são reconhecidamente eficientes contra insetos.

Compostos voláteis obtidos de extratos de plantas de arroz afetaram o desenvolvimento e sobrevivência principalmente de ninfas de primeiro ínstar e fềmeas recém emergidas de $S$. furcifera (Khan \& Saxena, 1986). Zhao et al. (1993) encontraram as enzimas carboxilesterase, fosfatase ácida e fosfatase alcalina em taxas mais elevadas nas cultivares de arroz resistentes a $N$. lugens. Estas enzimas diminuíram a digestibilidade do alimento ingerido, sendo a causa da redução significativa de populações do inseto em cultivares resistentes. 
Impropriedades nutricionais da planta como ausência, deficiência ou balanço inadequado de nutrientes essenciais ou não e vitaminas, podem influenciar aspectos vitais do inseto, como crescimento, metamorfose, reprodução, localização e seleção de hospedeiro. No balanço de nutrientes presentes nas plantas, as relações carboidratos-proteínas e carboidratos-ácidos graxos também devem ser consideradas. Os carboidratos estão presentes nas folhas das plantas na forma de açúcares solúveis como glicose, frutose e sacarose. A maior parte do nitrogênio presente nas folhas constitui as protéinas, enquanto que os ácidos graxos, geralmente em pequenas quantidades no tecido vegetal, são encontrados na forma de ácidos linolênico e linolêico (Panizzi \& Parra, 1991).

O valor nutritivo das plantas de arroz pode variar com o seu estádio de desenvolvimento. Teores de nitrogênio, carboidratos, gorduras, fibras e cinzas indicam que o valor nutritivo da planta aumenta durante o crescimento vegetativo, passando a diminuir a partir desta até a maturação. A mudança no valor nutritivo da planta está associada principalmente às variações do nível de nitrogênio, sendo que este em alta concentração favoreceria a nutrição de insetos (Hirano, 1964).

A palatabilidade de folhas e colmos de plantas de arroz para lagartas de Schoenobius incertulas é aumentada com a aplicação de fertilizantes nitrogenados (Ghosh, 1962). Maior suscetibilidade de plantas de arroz irrigado a D. saccharalis foi associada a doses crescentes de nitrogênio (Martins et al., 1978). Porém, em arroz de sequeiro, esta relação não foi observada (Martins et al., 1981).

O nitrogênio pode exercer efeito diferenciado na relação planta de arroz e adultos ou larvas de gorgulhos-aquáticos, em função da fonte do nutriente, época de aplicação e concentração nas plantas. $\mathrm{O}$ consumo de folhas de arroz por adultos de $L$. oryzophilus aumenta proporcionalmente com o incremento de nitrogênio total nas plantas (Bang \& Tugwell, 1976). Doses crescentes do nutriente, aplicadas em plantas de arroz antes da irrigação por inundação, foram associadas ao aumento da população larval de $L$. oryzophilus (Bowling, 1963). Resultados similares foram observados com o índice de infestação larval de L. brevirostris (Meneses \& Elizalde, 1980). Infestações de adultos de 
L. oryzophilus não foram afetadas por doses diferenciadas de nitrogênio aplicadas antes da irrigação por inundação de plantas de arroz, porém, a população larval foi associada com o aumento das doses do nutriente (Stout et al., 1998).

Nitrogênio na forma de uréia aplicado às plantas de arroz em cobertura na água de irrigação, não afetou a mortalidade de larvas de $O$. oryzae, contrariando hipóteses de efeito inseticida do fertilizante (Oliveira, 1980, 1981). Entretanto, Martins et al. (1986), através da aplicação de nitrogênio na forma de sulfato de amônio, observaram redução temporária da população larval do inseto e contribuição na recuperação do sistema radicular danificado.

A influência da composição química de cultivares de arroz sobre a nutrição e desenvolvimento de $D$. saccharalis, em dieta artificial contendo extratos aquosos de colmos, foi estudada por Martins et al. (1989), através do índice eficiência do alimento digerido. As dietas correspondentes às cultivares suscetíveis, apresentaram qualidade nutricional superior em relação às resistentes, sendo associada a sintomas de antibiose no inseto. Fatores químicos presentes em cultivares resistentes a $D$. saccharalis foram associados à redução da sobrevivência e maior período de desenvolvimento larval e a maior deformação nos adultos, afetando o potencial reprodutivo do inseto.

O teor de potássio na planta pode favorecer (Mishra \& Misra, 1992; Salim \& Saxena, 1991 e Samalo et al., 1991), prejudicar (Chen et al., 1994; Narayanasamy et al., 1976; Subbarao \& Perraju, 1976 e Sudhakar et al., 1991), ou ainda não apresentar relação definida (Hirano \& Ishii, 1961 e Ishii, 1967) com a intensidade de ataque de insetos-praga na cultura do arroz. S. furcifera (Mishra \& Misra, 1992 e Salim \& Saxena, 1991) e Scirpophaga incertulas (Samalo et al., 1991) tiveram desenvolvimento favorecido com aplicação de doses elevadas de potássio. Ao contrário, a incidência de C. suppressalis (Narayanasamy et al., 1976) e Cnaphalocrocis medinalis (Sudhakar et al., 1991) sobre plantas de arroz, foram correlacionadas negativamente com teores de potássio.

A exemplo do potássio, o fósforo também é um nutriente que apresenta efeitos variados no desenvolvimento de pragas sobre a cultura do arroz. Ishii (1967), 
Mishra et al. (1990) e Salim \& Saxena (1991) não observaram efeito do fósforo sobre o desenvolvimento de $C$. suppressalis, $S$. incertulas e $S$. furcifera em plantas de arroz, respectivamente. Correlações positivas foram encontradas entre concentrações de fósforo na planta de arroz e populações de Tryporyza incertulas (Narayanasamy et al., 1976), $S$. incertulas (Samalo et al., 1991) e $S$. furcifera (Mishra \& Misra, 1992). Entretanto, o fósforo contido no colmo de cultivares de arroz afetou o ataque de $C$. suppressalis (Chen et al., 1994).

Mishra \& Misra (1992) encontraram baixos teores de cálcio e magnésio em cultivares de arroz resistentes a $S$. furcifera, não exercendo portanto efeito sobre o inseto.

A sílica, mesmo não sendo essencial do ponto vista fisiológico, para o crescimento e desenvolvimento de plantas de arroz, possui importante participação na produção sustentável desta cultura (Epstein, 1994), além de afetar o desenvolvimento de insetos (Djamin \& Pathak, 1967 e Mishra \& Misra, 1992) e várias doenças fúngicas (Datnoff et al., 1991).

Alguns insetos pragas como C. suppressalis (Djamin \& Pathak, 1967 e Dravé \& Lauge, 1978), S. incertulas (Savant et al., 1994 e Yoshida, 1975), Chlorops oryzae, Nephotettis bipunctatus cinticeps (Maxuwell et al., 1972), N. lugens (Sujatha et al., 1987), S. furcifera (Kim \& Heirichs, 1982 e Salim \& Saxena, 1992), C. medinalis (Sudhakar et al., 1991 e Ramachandran \& Khan, 1991), T. incertulas (Subbarao \& Perraju, 1976), são afetados pelos altos teores de sílica em arroz. A infestação da brocado-colo, Elasmopalpus lignosellus, foi consideravelmente reduzida com a aplicação de sílica (Nakano et al., 1961). A sílica presente na cinza de casca de arroz, aplicada em viveiros de mudas de plantas de arroz, reduziu o índice de coração-morto por $E$. lignosellus, após o transplante (Savant et al., 1994).

Pelo fato de alguns genótipos serem mais eficientes no acúmulo de sílica que outros, é possível que isto contribua para a resistência de insetos (Deren et al., 1994 e Winslow, 1992;). Entretanto, o simples fato da planta possuir maior teor de sílica não a caracteriza como resistente, pois vários outros fatores podem estar relacionados (Savant 
et al., 1997). A silicificação da epiderme dificulta a penetração e a mastigação pelos insetos porque as células ficam mais endurecidas (Yoshida, 1975). Lagartas de $C$. suppressalis alimentadas com plantas contendo alto teor de silica apresentaram excessivo desgaste das mandibulas que se tornaram danificadas devido ao seu efeito abrasivo (Djamim \& Pathak, 1967 e Dravé \& Lauge, 1978).

A camada da epiderme de folhas de arroz selvagem, mais densa que de cultivares suscetíveis, foi associada a menores danos causados por $C$. medinalis (IRRI, 1991). A maior presença de células silicatadas nas folhas inibiu a alimentação de $C$. medinalis sobre tecido de plantas tratadas com sílica, resultando em redução do crescimento e desenvolvimento (IRRI, 1991). No estudo comparativo entre 24 cultivares de arroz, Sudhakar et al. (1991) encontraram maiores teores de sílica em plantas resistentes a C. medinalis. Resultados semelhantes foram observados por Ramachandran \& Khan (1991), onde níveis elevados de silica afetaram a oviposição, sobrevivência e desenvolvimento de C. medinalis.

A resistência a $N$. lugens foi correlacionada positivamente com o teor de sílica na planta de arroz. Maiores teores de sílica em cultivares de arroz, evidenciaram redução na fertilidade, longevidade e consequentemente no aumento da população do inseto (Sujatha et al., 1987). Ácido silícico, nas quantidades de $0,01 \mathrm{mg} / \mathrm{ml}$ na seiva, atuou como inibidor da alimentação de $N$. lugens (Yoshida et al., 1979). Metassilicato de sódio contendo $20 \%$ de $\mathrm{SiO}_{2}$ e casca de arroz contendo $14,5 \%$ de $\mathrm{SiO}_{2}$, reduzirarn as populações de Orseolia oryzae e C. medinalis, sendo o $\mathrm{SiO}_{2}$ proveniente da casca de arroz, mais eficiente sobre a segunda espécie (Subramanian \& Gopalaswamy, 1988).

A concentração de sílica aumenta durante o ciclo fenológico da planta, sendo encontrado níveis elevados na colheita (Lian, 1976). Desta forma, grãos armazenados de quatro cultivares de arroz apresentaram níveis diferenciados de infestação de $S$. cerealella, sendo o menor ataque da praga associado a maiores percentuais de sílica (Khanam et al., 1990).

No Brasil, há carência de informações sobre o efeito da sílica sobre insetos-praga e doenças importantes da cultura do arroz. Com estas evidências e 
considerando-se a importância da silica como nutriente no aumento da produção, é interessante a intensificação de investigações e ações neste sentido.

\subsection{Dinâmica de elementos químicos na planta}

O conhecimento de aspectos sobre absorção, concentração, translocação e função dos elementos na parte aérea e sistema radicular das plantas de arroz, é importante, pois facilita entender a sua possível associação com a intensidade de ataque de O. oryzae.

\subsubsection{Nitrogênio}

O teor de nitrogênio no tecido vegetal varia com a espécie, cultivar, parte, desenvolvimento e estado nutricional da planta, situando-se entre 0,5 e $5 \%$, sendo encontrado em arroz de 2 a 4\%. O nitrogênio é absorvido pelas plantas em forma de gás, aminoácidos e, predominantemente, nas condições naturais e aeróbicas, sendo transportado no xilema e redistribuído principalmente no floema, em processos relativamente rápidos.

O nitrogênio participa estruturalmente na formação de aminoácidos e proteínas; bases nitrogenadas e ácidos nucléicos; enzimas e coenzimas; vitaminas; pigmentos e produtos secundários. É essencial nos processos de absorção iônica, fotossíntese, respiração, sínteses, multiplicação e diferenciação celulares e herança genética. Possui papel fundamental na quantidade e qualidade da produção, bem como estimulando a formação de gemas reprodutivas e aumentando o perfilhamento e o teor de proteínas (Malavolta, 1987 e Malavolta \& Barbosa Filho, 1983). 


\subsubsection{Fósforo}

O teor no fósforo no tecido vegetal varia em geral de 0,08 a $1,5 \%$. O fósforo é absorvido predominantemente na forma iônica $\mathrm{H}_{2} \mathrm{PO}_{4}{ }^{\circ}$; sua acumulação nas células corticais da raiz é seguida pela transferência até o xilema e prontamente deslocase às folhas e regiões de crescimento. Juntamente com o nitrogênio, o fósforo é o elemento mais rapidamente redistribuído na planta.

O fósforo participa na estrutura de ésteres de carboidratos, fosfolipídeos, coenzimas e ácidos nucléicos, nos processos de armazenamento e transferência de energia na planta. Intensifica a formação de raízes, aumenta e acelera a frutificação, aumenta o teor de carboidratos, óleos, gorduras e proteínas (Malavolta, 1980, 1987).

\subsubsection{Potássio}

O teor de potássio no tecido vegetal varia de 0,2 a $10 \%$. É absorvido pelas raízes na forma iônica $\mathrm{K}^{+}$, em processo essencialmente ativo, sendo facilitado pela presença de cálcio. É transportado pelo xilema e redistribuído na planta pelo floema. As raízes contêm cerca de $16 \%$ do total de potássio da planta, sendo que nas folhas está mais concentrado no citoplasma, núcleo e cloroplastos.

O potássio é essencial nos processos osmóticos, na síntese de proteínas e na manutenção da sua estabilidade, abertura e fechamento de estômatos, permeabilidade da membrana, fotossíntese, transporte de carboidratos, respiração, síntese e fixação simbiótica do nitrogênio. A exigência de níveis elevados de potássio está relacionada à necessidade de altas concentrações no citoplasma para garantir as atividades enzimáticas. A grande diferença, quando comparado a outros nutrientes, é que o potássio não faz parte de nenhum composto dentro da planta. Intensifica a lignificação das células esclerenquimáticas e aumenta a espessura das paredes celulares do colmo, estimula o perfilhamento, aumenta o teor de carboidratos, gorduras, óleos e proteínas; estimula o enchimento de grãos diminuindo o chochamento, promove o armazenamento de açúcar e 
amido e aumenta a utilização de água (Barbosa Filho, 1987; Malavolta, 1987 e Malavolta \& Barbosa Filho, 1987).

\subsubsection{Cálcio}

É absorvido pelas raizes na forma iônica $\mathrm{Ca}^{2+}$ e seu teor no tecido vegetal varia de 0,05 a $2 \%$. Exerce uma função estrutural, fazendo parte da parede celular como pectato de cálcio, atuando como cimento entre as células. É essencial para manter a integridade estrutural das membranas e paredes celulares, atuando no crescimento e desenvolvimento da planta, senescência e abcisão. Participa na formação de pectatos, carbonatos, oxalatos, fitatos e calmadulinas; funcionamento de membranas, absorção iônica, reação com hormônios vegetais e ativação enzimática, estimula o desenvolvimento das raízes; auxilia na fixação simbiótica do nitrogênio e na eficiência da polinização, sendo indispensável para a germinação do grão de pólen e para o crescimento do tubo polínico (Barbosa Filho, 1987 e Malavolta, 1980, 1987).

\subsubsection{Magnésio}

É absorvido como $\mathrm{Mg}^{2+}$ e seu teor no tecido vegetal varia de 0,02 a $2,5 \%$. Altas concentrações de cálcio e potássio no meio dificultam a absorção de magnésio, causando às vezes sua deficiência. A exemplo do potássio e cálcio, é móvel no floema, sendo os sintomas de deficiência externados nas folhas mais velhas.

O magnésio está presente na clorofila, tendo grande participação na fotossintese, pois $50 \%$ deste nutriente encontra-se nos cloroplastos e contribui com $2,7 \%$ para o peso da clorofila. Além disso, é ativador enzimático e carregador de fósforo. $\mathrm{O}$ magnésio colabora em todas as funções em que o fósforo está presente (Barbosa Filho, 1987 e Malavolta, 1987). 


\subsubsection{Sílica}

A sílica é absorvida na forma de ácido monossilícico. Na seiva bruta do arroz, seu teor é centena de vezes mais elevado que a concentração no meio, sendo encontrado na época da colheita em índices que variam de 2 a 6\%. A maior proporção na planta, entretanto, é a da sílica amorfa hidratada. Depois de solidificada toma-se imóvel na planta. Nas células epidérmicas do arroz, abaixo da cutícula, aparece uma camada de sílica a qual auxilia na diminuição da perda de água por transpiração, além de formar uma barreira à penetração de patógenos e alimentação de insetos.

A essencialidade da sílica na planta foi demonstrada indiretamente, já que, em sua falta, diversas espécies não completam o ciclo e mostram sintomas de deficiência, crescimento retardado e clorose internerval das folhas maduras. Principalmente em países Asiáticos e na Flórida (EUA), a adubação com compostos contendo sílica é bastante freqüente. A importância da sílica para o arroz tem sido associada à sua capacidade de aumentar a produção de grãos através da diminuição da toxidez de ferro e manganês e do aumento da disponibilidade de fósforo, devido à liberação de fosfatos de ferro (Barbosa Filho, 1987; Deren et al., 1992; Malavolta, 1980, 1987 e Malavolta \& Barbosa Filho, 1983).

\subsubsection{Lignina}

A maioria dos vegetais superiores contém pelo menos alguma fração de lignina, sendo freqüente um teor que oscila de 4 a 12\%; em vegetais fibrosos como o arroz, porém este teor pode chegar a $20 \%$ da matéria seca. O termo lignina é usado para designar um grupo de substâncias com unidades químicas semelhantes. A estrutura química da lignina é muito complexa e ainda não muito bem definida. São polímeros ligados em proporções variadas e em seqüência casualizada, originando assim, grande variedade de produtos, o que dificulta a sua exata definição. A lignina também se 
constitui na fração menos digestível do vegetal e aumenta seu teor com a maturação da planta (Barbosa Filho, 1987 e Malavolta, 1987). 


\section{MATERIAL E MÉTODOS}

\subsection{Local}

A associação de caracteres químicos de cultivares de arroz irrigado com danos de Oryzophagus oryzae (Costa Lima, 1936) (Coleoptera: Curculionidae) foi avaliada em experimentos instalados na Empresa Brasileira de Pesquisa Agropecuária (Embrapa), Centro de Pesquisa Agropecuária de Clima Temperado (CPACT), Estação Experimental de Terras Baixas (ETB), Pelotas, RS ( $\left.31^{\circ} 52^{\prime} \mathrm{S}, 52^{\circ} 21^{\prime} \mathrm{WGR}\right)$.

\subsection{Cultivares}

As cultivares de arroz irrigado BR-IRGA 410, Dawn, BRS FIRMEZA e BRS ATALANTA foram selecionadas por apresentarem diferenciação em seu ciclo de desenvolvimento, no grau de resistência a $O$. oryzae e por serem cultivadas em escala significativa nas lavouras comerciais do Rio Grande do Sul.

As cultivares BR-IRGA 410 e BRS ATALANTA pertencem ao grupo de plantas "moderno-filipino". BR-IRGA 410 possui folhas pilosas, ciclo biológico de 120 dias e resistência moderada ao inseto, enquanto BRS ATALANTA possui folhas lisas, ciclo biológico de aproximadamente 100 dias e alta resistência ao ataque de O. oryzae. As cultivares Dawn e BRS FIRMEZA são do tipo “moderno-americano”. 'Dawn' possui folhas lisas, ciclo biológico de 135 dias e resistência moderada ao inseto, enquanto 'BRS FIRMEZA' possui folhas lisas, ciclo biológico de 120 dias e suscetibilidade a $O$. oryzae (Martins et al., 1993; Martins \& Terres, 1995 e Terres et al., 1999). 


\subsection{Experimentos}

\subsubsection{Com chance de escolha}

O experimento foi instalado no ano agrícola 1997/98 e repetido em 1998/99.

Dez parcelas, medindo $96 \mathrm{~cm}$ de comprimento e 80 de largura, contendo 48 plantas de arroz das quatro cultivares descritas, foram instaladas em 10 de dezembro de 1997 e 14 de novembro de 1998. As plantas, em 4 linhas espaçadas a $20 \mathrm{~cm} \mathrm{e}$ distanciadas a $8 \mathrm{~cm}$, foram dispostas em grupos de três, aleatoriamente, no interior da parcela (Figura 1).

Aos 25 após a emergência das plântulas (DAE), gaiolas revestidas com tela de náilon $\left(1 \mathrm{~mm}^{2}\right)$, medindo $1,10 \times 0,90 \times 0,80 \mathrm{~m}$ de comprimento, largura e altura, respectivamente, foram colocadas sobre as parcelas (Figura 2). Logo após, as plantas de cinco parcelas foram infestadas com 48 casais em cópula (1 casal/planta) de $O$. oryzae (Figura 3) coletados em lavouras comerciais adjacentes ao local do experimento, permanecendo outras cinco parcelas, livres do ataque do inseto.

\subsubsection{Sem chance de escolha}

Neste experimento, foram utilizadas as quatro cultivares descritas anteriormente, com seis repetições, mantendo, para cada parcela infestada, uma adjacente livre do ataque do inseto, totalizando 48 parcelas. A instalação e as datas de infestação foram similares às do experimento com chance de escolha. Gaiolas revestidas de tela de náilon $\left(1 \mathrm{~mm}^{2}\right)$, medindo $0,50 \times 0,50 \times 1,30 \mathrm{~m}$ de comprimento, largura e altura, respectivamente, abrigaram três plantas da mesma cultivar, possibilitando assim o ataque de $O$. oryzae sem chance de escolha (Figura 4). Três casais em cópula (1 casal/planta) foram utilizados para infestar as plantas de cada parcela. 


\begin{tabular}{|c|c|c|c|}
\hline $\mathbf{A}$ & D & B & $\mathbf{C}$ \\
\hline $\mathbf{A}$ & D & B & $\mathbf{C}$ \\
\hline $\mathbf{A}$ & D & B & C \\
\hline D & $\mathbf{C}$ & $\mathbf{A}$ & B \\
\hline D & C & $\mathbf{A}$ & B \\
\hline D & C & $\mathbf{A}$ & B \\
\hline C & B & D & $\mathbf{A}$ \\
\hline C & $\mathbf{B}$ & D & $\mathbf{A}$ \\
\hline C & $\mathbf{B}$ & D & $\mathbf{A}$ \\
\hline B & $\mathbf{A}$ & C & D \\
\hline $\mathbf{B}$ & $\mathbf{A}$ & C & D \\
\hline B & $\mathbf{A}$ & C & D \\
\hline
\end{tabular}

Figura 1. Distribuição das plantas das quatro cultivares de arroz (A, B, C e D) na parcela experimental. Experimento com chance de escolha. Pelotas, RS, 1997/98 e 1998/99.

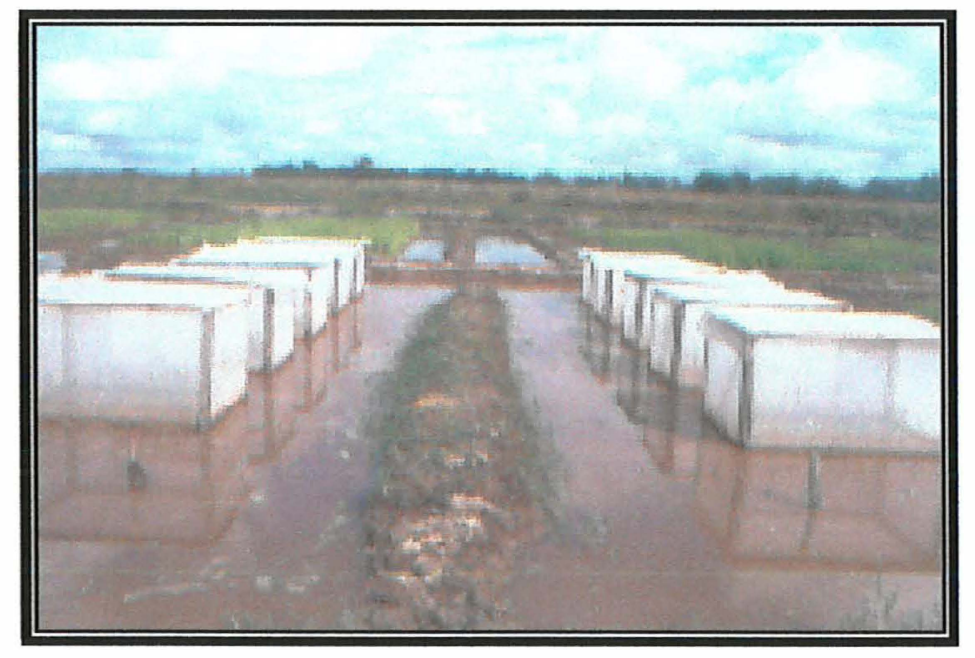

Figura 2. Gaiolas revestidas de tela de náilon sobre plantas no experimento com chance de escolha. Pelotas, RS, 1997/98 e 1998/99. 


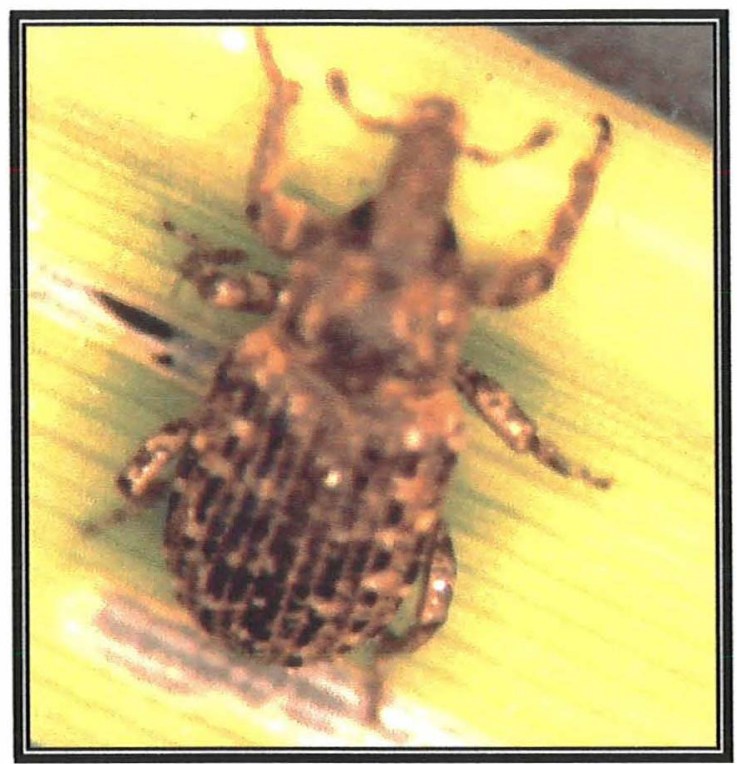

Figura 3. Adulto de Oryzophagus oryzae utilizado para infestação nos experimentos com e sem chance de escolha. Pelotas, RS, 1997/98 e 1998/99.

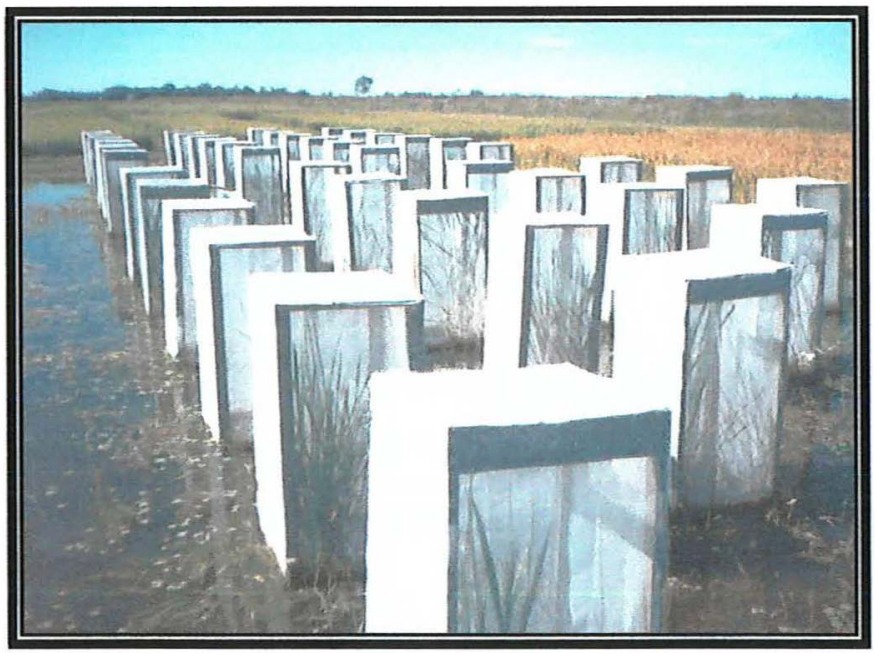

Figura 4. Gaiolas revestidas de tela de náilon sobre plantas no experimento sem chance de escolha. Pelotas, RS, 1997/98 e 1998/99. 


\subsection{Manejo do solo e práticas culturais}

O manejo do solo e as práticas culturais foram realizadas com objetivo de simular ao máximo, as condições verificadas em lavouras comerciais. Para preparo do solo, utilizou-se o método convencional, com aração seguida de gradagem e nivelamento. De acordo com a análise do solo, a adubação de base foi realizada a lanço em área total. A adubação nitrogenada foi realizada em dose única, também a lanço, na diferenciação do primórdio floral, seguindo as Recomendações Técnicas da Cultura do Arroz Irrigado para a região Sul do Brasil (IRGA, 1995).

A irrigação por inundação, realizada no dia que antecedeu as infestações com o inseto, consistiu em uma lâmina de água uniforme de aproximadamente $15 \mathrm{~cm}$, que permaneceu constante até a maturação e colheita das plantas.

\subsection{Variáveis Avaliadas}

Aos cinco dias após a infestação, correspondendo a 30 DAE, em uma e quatro plantas por parcela, nos experimentos sem e com chance de escolha, respectivamente, foi avaliado o número de lesões nas folhas e de ovos nas bainhas foliares, em plantas infestadas por $O$. oryzae e os teores de nitrogênio, sílica, lignina, fósforo, cálcio e magnésio na parte aérea e raízes de plantas infestadas e livres do ataque do inseto.

Aos 25 dias após a infestação, 55 DAE, nos dois anos de experimentação e no mesmo número de plantas citado anteriormente, foram determinados o número e peso de larvas de $O$. oryzae e o teor dos mesmos elementos químicos na parte aérea e raízes das plantas.

$\mathrm{Na}$ colheita, seguindo o procedimento descrito para as avaliações anteriores, os elementos químicos das plantas foram novamente quantificados, e nos experimentos com chance de escolha, foi determinada a produção de grãos. 


\subsubsection{Inseto}

\subsubsection{Lesões na folha}

Ao se alimentarem através da raspagem da epiderme do parênquima foliar no sentido longitudinal entre as nervuras das folhas de plantas de arroz, os adultos de $O$. oryzae provocam lesões longitudinais que variam de 1,5 a 3,0 cm de comprimento e aproximadamente 1,5 mm de largura (Martins \& Ferreira, 1980 e Prando, 1999). Estes sinais foram quantificados em todas as folhas da planta (Figura 5).

\subsubsection{Número de ovos}

As fêmeas de $O$. oryzae depositam ovos de forma individualizada nas lacunas aeríferas da bainha foliar do arroz (Figura 6), preferencialmente nas partes submersas (Moreira, 1996; Moreira et al., 1996 e Prando, 1999). Para quantificação dos ovos, foi adaptada metodologia de Gifford \& Trahan (1969), em que as bainhas foliares permaneceram imersas no interior de placas de Petri, por um período de 30 dias, em solução de álcool a $70 \%$ contendo fucsina ácida em quantidade suficiente para a solução atingir coloração violeta intenso. Com este procedimento, ocorreu clareamento da bainha foliar, com a remoção de parte da clorofila pelo álcool, e intensificação da coloração dos ovos, pela ação da fucsina. Antes da contagem dos ovos através de microscópio estereoscópico, as bainhas foliares foram lavadas com álcool 70\%, visando à remoção do excesso de corante.

\subsubsection{Número de larvas}

O número de larvas (Figura 7) por planta (amostra) foi determinado através da técnica de amostragem adaptada de Tugwell \& Stephen (1981). Amostras de 


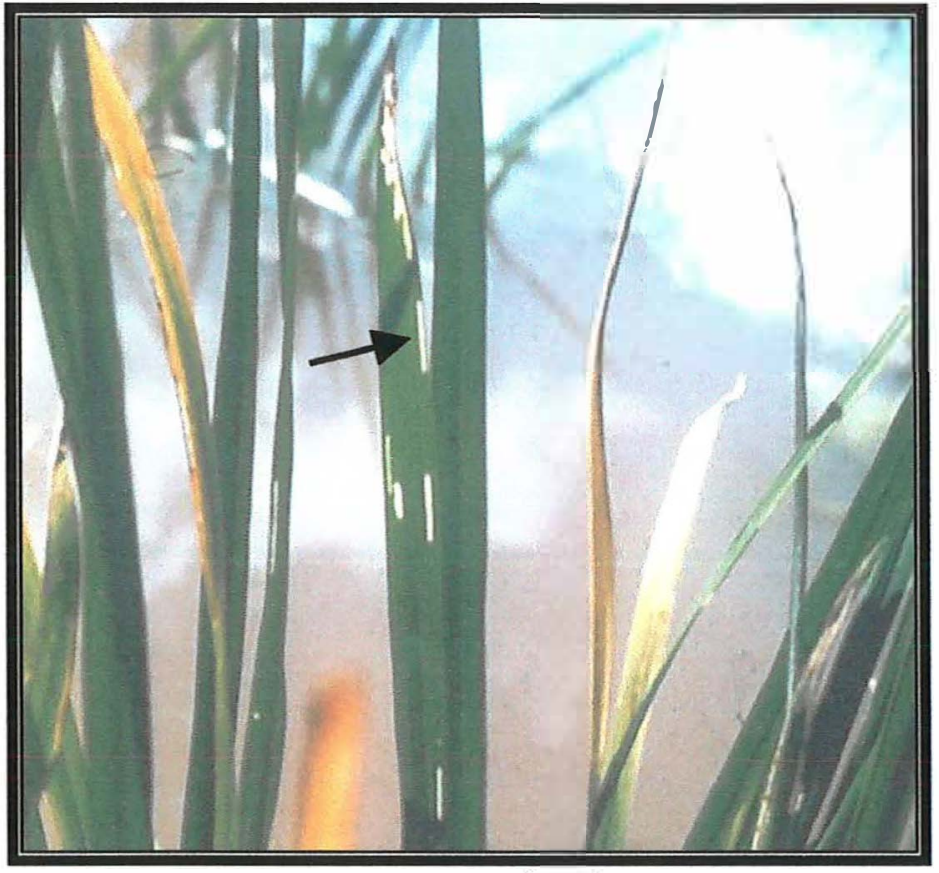

Figura 5. Lesões nas folhas de plantas de arroz provocadas pela alimentação de adultos de Oryzophagus oryzae. Pelotas, RS, $1997 / 98$ e 1998/99.

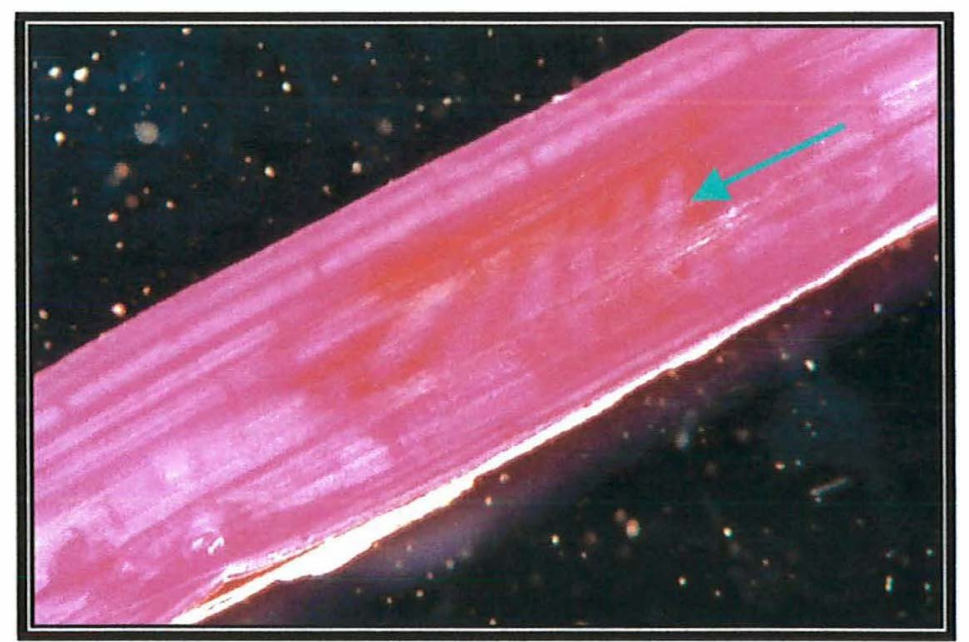

Figura 6. Oviposição endofitica de Oryzophagus oryzae no parênquima aerífero da bainha foliar de plantas de arroz. Pelotas, RS, $1997 / 98$ e 1998/99. 


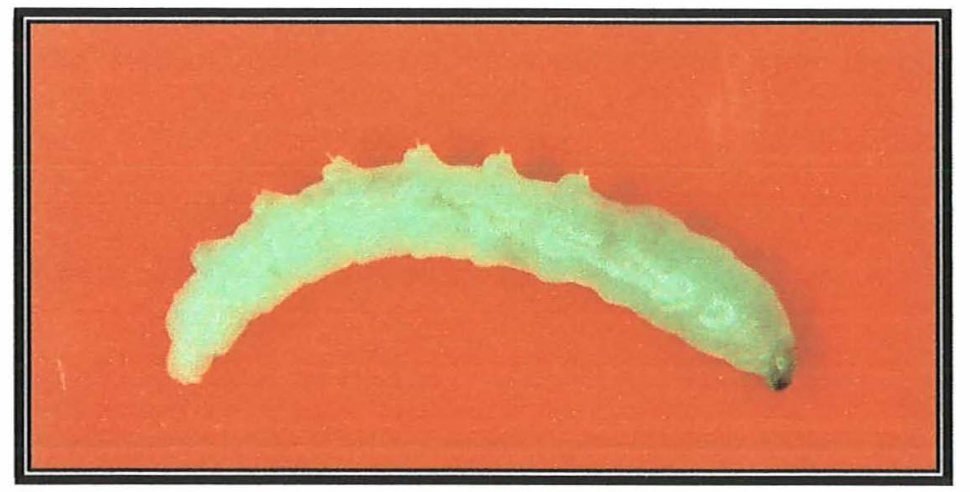

Figura 7. Larva de Oryzophagus oryzae coletada 30 dias após a infestação de plantas de arroz por adultos do inseto. Pelotas, RS, 1997/98 e 1998/99.

solo e raízes foram retiradas com amostrador (secção de cano de PVC) de $10 \mathrm{~cm}$ de diâmetro aprofundado aproximadamente $8,5 \mathrm{~cm}$ no solo, ao redor da base da planta.

As amostras foram agitadas sob água, em peneira com fundo de tela de náilon (malha de $1 \mathrm{~mm}^{2}$ de diâmetro), para liberar as larvas das raízes e do solo.

\subsubsection{Peso de larvas}

Após a contagem, as larvas acondicionadas em recipiente contendo água, foram transferidas para laboratório, permanecendo sobre papel toalha até a remoção da água contida na parte exterthl das mesmas. Imediatamente após, foram pesadas conjuntamente por platlta (dłhostra), em balança de precisão. Com base no peso e no número total de larvas por planta, foi determinado o peso médio larval. 


\subsubsection{Planta}

Para as três épocas de determinação dos elementos químicos da planta, o sistema radicular foi separado da parte aérea, em laboratório, e lavado em jato d'água para remoção do solo aderido às raízes. Imediatamente após, as duas partes da planta, devidamente identificadas, foram mantidas em estufa a $60^{\circ} \mathrm{C}$, até peso constante. Em seguida, o material foi moído, sendo então adotados os procedimentos necessários para a quantificação dos elementos químicos.

\subsubsection{Elementos químicos}

A quantificação dos elementos químicos foi feita no Laboratório de Bromatologia e Nutrição Animal, junto à ETB da Embrapa Clima Temperado.

Nitrogênio, fósforo, potássio, cálcio e magnésio foram determinados através da metodologia proposta por Tedesco et al. (1985), a qual possibilita a recuperação destes nutrientes de forma semelhante à obtida com os métodos de Kjeldahl para nitrogênio e por digestão nítrico-perclórica para os demais nutrientes (Bremner, 1965). Para determinação de lignina e silica, foi utilizado o método do ácido sulfúrico a 72\%, seguindo metodologia proposta por Silva (1990).

\subsubsection{Produção de grãos}

A produção de grãos, obtida por debulha manual das panículas, foi feita apenas nos experimentos com chance de escolha, sendo a redução de produção de grãos determinada pela diferença entre plantas não infestadas e infestadas pelo inseto. 


\subsection{Análise estatística}

As variáveis avaliadas referentes ao inseto e à planta foram submetidas à análise da variância conjuntamente para os dois anos de experimentação, sendo as médias comparadas pelo teste de Tukey a 5\%. Quando necessário, os dados foram transformados conforme indicado por teste de homocedasticidade. Correlações lineares entre as variáveis avaliadas foram estabelecidas e as significâncias determinadas pelo teste “t” a 1; 5 e 10\%. As análises estatísticas foram realizadas com base no pacote estatístico SANEST (Zonta, 1986). 


\section{RESULTADOS E DISCUSSÃO}

\subsection{Efeito de elementos químicos de cultivares de arroz sobre Oryzophagus oryzae}

\subsubsection{Fase adulta}

\subsubsection{Alimentação}

As cultivares de arroz irrigado avaliadas apresentaram diferença significativa na porcentagem de folhas lesionadas pela alimentação de adultos de $O$. oryzae, nas condições com e sem chance de escolha do hospedeiro. Em ambas as condições foi observado menor número de folhas lesionadas em 'BRS FIRMEZA' e 'Dawn' que em 'BR-IRGA 410' e 'BRS ATALANTA' (Figura 8 A e B).

$\mathrm{O}$ teor de elementos químicos na parte aérea das quatro cultivares de arroz, quantificados 30 dias após a emergência (DAE) das plantas, diferiu significativamente em relação a nitrogênio, sílica, magnésio e potássio. Maiores teores de nitrogênio foram encontrados nas cultivares BR IRGA 410 e BRS ATANTA, sílica na 'BRS FIRMEZA', magnésio na 'BRS ATALANTA' e potássio na 'BR-IRGA 410' (Tabela 1).

Correlações estabelecidas entre o teor dos elementos e a porcentagem de folhas lesionadas pela alimentação de adultos de $O$. oryzae foram positivas para nitrogênio e negativas para sílica, em ambas as condições de escolha do hospedeiro. Para o teor de potássio, só houve correlação (positiva) nos experimentos sem chance de escolha (Tabela 2). A menor porcentagem de folhas lesionadas nas cultivares com maior teor de sílica sugere efeito negativo deste elemento sobre a alimentação de $O$. oryzae. 
A

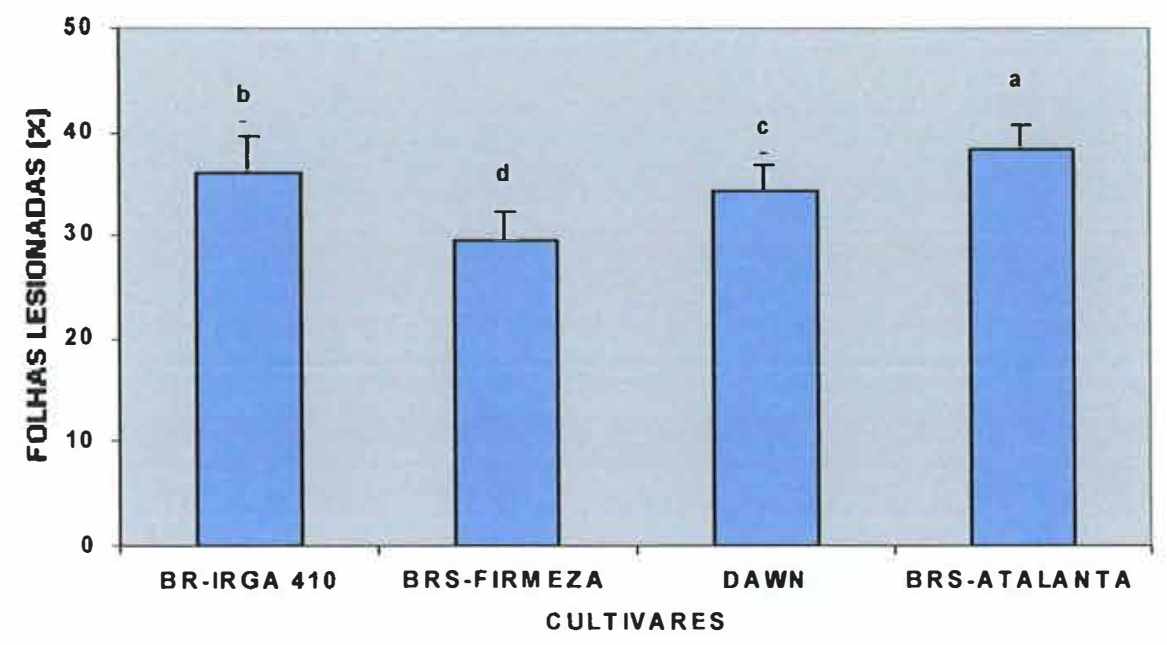

B

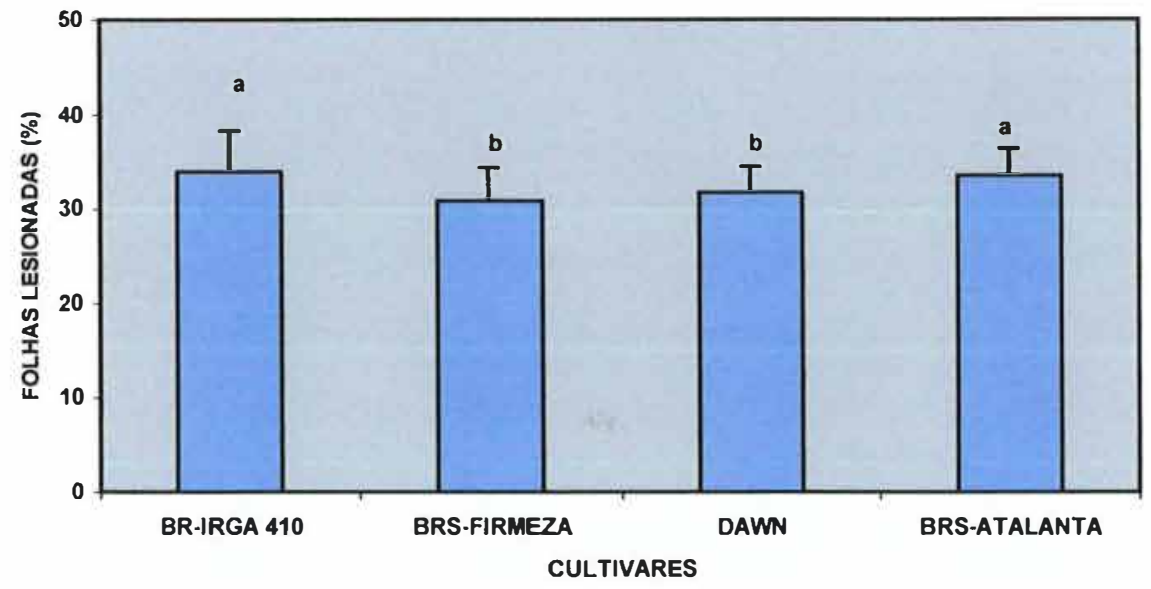

Figura 8. Porcentagem de folhas lesionadas por adultos de Oryzophagus oryzae, em cultivares de arroz irrigado, 30 dias após a emergência das plantas. Experimentos com (A) e sem (B) chance de escolha. Pelotas, RS, 1997/98 e 1998/99. Médias ( \pm EP) seguidas por letras distintas diferem pelo teste de Tukey $(\mathrm{P} \leq 0,05)$. 
Tabela 1. Porcentagem de elementos químicos na parte aérea de cultivares de arroz irrigado, 30 dias após a emergência das plantas, em experimentos $\mathrm{com}^{1}$ e sem ${ }^{2}$ chance de escolha. Pelotas, RS, 1997/98 e 1998/999.

\begin{tabular}{|c|c|c|c|c|c|}
\hline \multirow{2}{*}{$\begin{array}{l}\text { Elementos } \\
\text { Químicos }\end{array}$} & \multicolumn{4}{|c|}{ Cultivares } & \multirow[t]{2}{*}{ C.V. (\%) } \\
\hline & BR-IRGA 410 & BRS FIRMEZA & $\overline{\text { DAWN }}$ & BRS ATALANTA & \\
\hline Nitrogênio $^{\top}$ & $3,81 \pm 0,12 \mathrm{a}$ & $3,33 \pm 0,08 b$ & $3,42 \pm 0,11 b$ & $3,61 \pm 0,10 a$ & 1,5 \\
\hline Nitrogênio $^{2}$ & $3,79 \pm 0,08 \mathrm{a}$ & $3,31 \pm 0,07 b$ & $3,40 \pm 0,10 b$ & $3,59 \pm 0,09 \mathrm{a}$ & 1,8 \\
\hline Sílica $^{1}$ & $0,94 \pm 0,04 b$ & $1,11 \pm 0,05 \mathrm{a}$ & $0,99 \pm 0,04 b$ & $0,98 \pm 0,03 b$ & 3,7 \\
\hline Sílica $^{2}$ & $0,90 \pm 0,02 b$ & $1,07 \pm 0,02 a$ & $1,01 \pm 0,03 b$ & $0,94 \pm 0,03 b$ & 2,9 \\
\hline Lignina $^{1}$ & $1,32 \pm 0,08 \mathrm{a}$ & $1,42 \pm 0,10 a$ & $1,28 \pm 0,09 \mathrm{a}$ & $1,25 \pm 0,10 a$ & 4,3 \\
\hline Lignina $^{2}$ & $1,31 \pm 0,09 \mathrm{a}$ & $1,40 \pm 0,11 \mathrm{a}$ & $1,28 \pm 0,08 \mathrm{a}$ & $1,24 \pm 0,07 \mathrm{a}$ & 3,9 \\
\hline Fósforo ${ }^{1}$ & $0,36 \pm 0,03 \mathrm{a}$ & $0,35 \pm 0,05 a$ & $0,32 \pm 0,01 \mathrm{a}$ & $0,38 \pm 0,07 a$ & 6,1 \\
\hline Fósforo ${ }^{2}$ & $0,35 \pm 0,05 \mathrm{a}$ & $0,34 \pm 0,06 \mathrm{a}$ & $0,31 \pm 0,02 a$ & $0,37 \pm 0,06 \mathrm{a}$ & 5,9 \\
\hline Cálcio ${ }^{1}$ & $0,32 \pm 0,02 \mathrm{a}$ & $0,31 \pm 0,03 \mathrm{a}$ & $0,29 \pm 0,01$ a & $0,31 \pm 0,02 \mathrm{a}$ & 3,8 \\
\hline Cálcio $^{2}$ & $0,33 \pm 0,03 \mathrm{a}$ & $0,32 \pm 0,04 \mathrm{a}$ & $0,30 \pm 0,03 \mathrm{a}$ & $0,32 \pm 0,02 a$ & 4,1 \\
\hline Magnésio ${ }^{1}$ & $0,25 \pm 0,01 \mathrm{ab}$ & $0,25 \pm 0,01 \mathrm{ab}$ & $0,23 \pm 0,01 b$ & $0,27 \pm 0,01 \mathrm{a}$ & 5,4 \\
\hline Magnésio $^{2}$ & $0,26 \pm 0,01 \mathrm{ab}$ & $0,26 \pm 0,02 \mathrm{ab}$ & $0,24 \pm 0,01 \mathrm{~b}$ & $0,28 \pm 0,02 \mathrm{a}$ & 4,9 \\
\hline Potássio $^{1}$ & $1,90 \pm 0,08 \mathrm{a}$ & $1,70 \pm 0,06 b$ & $1,70 \pm 0,05 b$ & $1,75 \pm 0,07 b$ & 2,1 \\
\hline Potássio $^{2}$ & $1,91 \pm 0,09 \mathrm{a}$ & $1,71 \pm 0,05 b$ & $1,71 \pm 0,06 b$ & $1,76 \pm 0,08 b$ & 2,1 \\
\hline
\end{tabular}

Médias ( $(\mathrm{EP})$ seguidas por letras distintas na mesma linha diferem pelo teste de Tukey $(\mathrm{P} \leq 0,05)$.

O fato de o coeficiente de correlação linear ter sido maior no experimento sem chance de escolha sugere que, nessas condições, o efeito negativo da sílica sobre a alimentação do inseto foi aparentemente maior que no experimento com chance de escolha.

A sílica, nutriente presente em teores elevados na planta de arroz, exerce efeito negativo na alimentação de diversas espécies de insetos-pragas, principalmente as de hábito mastigador (Kim \& Heirichs, 1982; Salim \& Saxena, 1992; Savant et al., 1994; Sujatha et al., 1987; Subbarao \& Perraju, 1976 e Yoshida, 1975), pelo desgaste das mandíbulas, provocado pelo efeito abrasivo (Djamin \& Pathak, 1967; Dravé \& 
Tabela 2. Coeficientes de correlação linear (r) entre folhas lesionadas por adultos de Oryzophagus oryzae e porcentagem de elementos químicos da parte aérea da planta em cultivares de arroz irrigado, 30 dias após a emergência das plantas. Experimentos com e sem chance de escolha. Pelotas, RS, 1997/98.

\begin{tabular}{|c|c|c|c|c|c|c|}
\hline \multicolumn{3}{|c|}{ Combinações de Variáveis } & \multicolumn{2}{|c|}{ Com Chance } & \multicolumn{2}{|c|}{ Sem Chance } \\
\hline & & & $\mathbf{N}^{1}$ & $\mathbf{r}$ & $\mathbf{N}^{1}$ & $\bar{r}$ \\
\hline Folhas lesionadas & $\mathrm{x}$ & Nitrogênio & 4 & $0,775^{*}$ & 4 & $0,946^{*}$ \\
\hline Folhas lesionadas & $\mathbf{x}$ & Lignina & 4 & $-0,643$ & 4 & $-0,419$ \\
\hline Folhas lesionadas & $\mathrm{x}$ & Sílica & 4 & $-0,881^{*}$ & 4 & $-0,982^{*}$ \\
\hline Folhas lesionadas & $\mathrm{x}$ & Fósforo & 4 & 0,405 & 4 & 0,507 \\
\hline Folhas lesionadas & $\mathrm{x}$ & Cálcio & 4 & 0,132 & 4 & 0,519 \\
\hline Folhas lesionadas & $\mathrm{x}$ & Magnésio & 4 & 0,417 & 4 & 0,428 \\
\hline Folhas lesionadas & $\mathrm{x}$ & Potássio & 4 & 0,408 & 4 & $0,801^{*}$ \\
\hline
\end{tabular}

Número de combinações entre variáveis.

"Significativo pelo teste " $t$ " a $1 \%(r \geq 0,917), 5 \%(r \geq 0,811)$ e $10 \%(r \geq 0,729)$.

Lauge, 1978; Nakano et al., 1961 e Ramachandran \& Khan1991). Ademais, é crescente a utilização da sílica como nutriente essencial para o aumento da produção (Epstein, 1994) e seu efeito como barreira para penetração de patógenos na planta (Datnoff et al., 1992), o que intensifica a importância deste elemento nos programas de melhoramento genético da cultura do arroz.

$\mathrm{O}$ nitrogênio é um nutriente que em teores mais elevados nas plantas de arroz, aumenta a suscetibilidade destas ao ataque de insetos (Bang \& Tugwell, 1976; Bowling, 1963; Ghosh, 1962; Hirano, 1964; Martins et al., 1978, 1981, 1986, 1989; Meneses \& Elizalde, 1980; Oliveira, 1980, 1981 e Stout et al., 1998), por torna-las mais atraentes e estimulantes à alimentação. Porém a influência do potássio na planta sobre o comportamento alimentar de insetos é controversa, sendo associado tanto com a estimulação (Mishra \& Misra, 1992; Salim \& Saxena, 1991 e Samalo et al., 1991) como com a inibição (Chen et al., 1994; Narayanasamy et al., 1976; Subbarao \& Perraju, 1976 
e Sudhakar et al., 1991) da alimentação. O efeito positivo destes nutrientes na alimentação de adultos pode estar associado com a presença de maiores teores de aminoácidos livres, ácidos diversos e flavonóides na seiva da planta, visto também serem responsáveis pela síntese destas substâncias (Auclair et. Al., 1982; Auclair \& Baldos 1982; Ishii et al., 1962 e Munakata et al., 1959).

\subsubsection{Oviposição}

As plantas de arroz das cultivares avaliadas foram diferentemente preferidas para a oviposição de $O$. oryzae. Maior número de ovos foi encontrado nas cultivares BR-IRGA 410 e BRS ATALANTA que em 'BRS FIRMEZA' e 'Dawn', em ambas as condições de escolha do hospedeiro (Figura 9 A e B). Entretanto, as cultivares, quando avaliadas individualmente (experimento sem chance), apresentarem menor número de ovos em relação à avaliação conjunta (com chance). Nas duas condições, as cultivares mais preferidas para oviposição também foram aquelas mais preferidas para alimentação dos adultos, porém, a correlação entre porcentagem de folhas lesionadas e número de ovos por planta somente foi observada nos experimentos sem chance de escolha (Tabela 3).

Nas correlações estabelecidas entre o teor de elementos na parte aérea das plantas 30 DAE (Tabela 2) e o número de ovos de $O$. oryzae, houve significância positiva com nitrogênio, cálcio e potássio, em ambas as condições de escolha do hospedeiro, e com fósforo, apenas em sem chance. Correlação negativa somente foi observada com sílica, nas duas condições de escolha do hospedeiro (Tabela 3).

Ao ovipositar endofiticamente nas bainhas foliares, as fềmeas de $O$. oryzae abrem com o rostro um pequeno orifício na epiderme foliar (Prando, 1999). Este comportamento, similar o da alimentação, provavelmente explique a menor oviposição do inseto nas plantas com maior teor de sílica na parte aérea.. A exemplo do ocorrido com a alimentação de adultos de $O$. oryzae, é freqüente a associação de maiores teores

de nitrogênio com a oviposição de insetos (Bowling, 1963; Meneses \& Elizalde, 1980 e Stout et al., 1998). Entretanto, em relação ao potássio, fósforo e cálcio presente na parte 
A

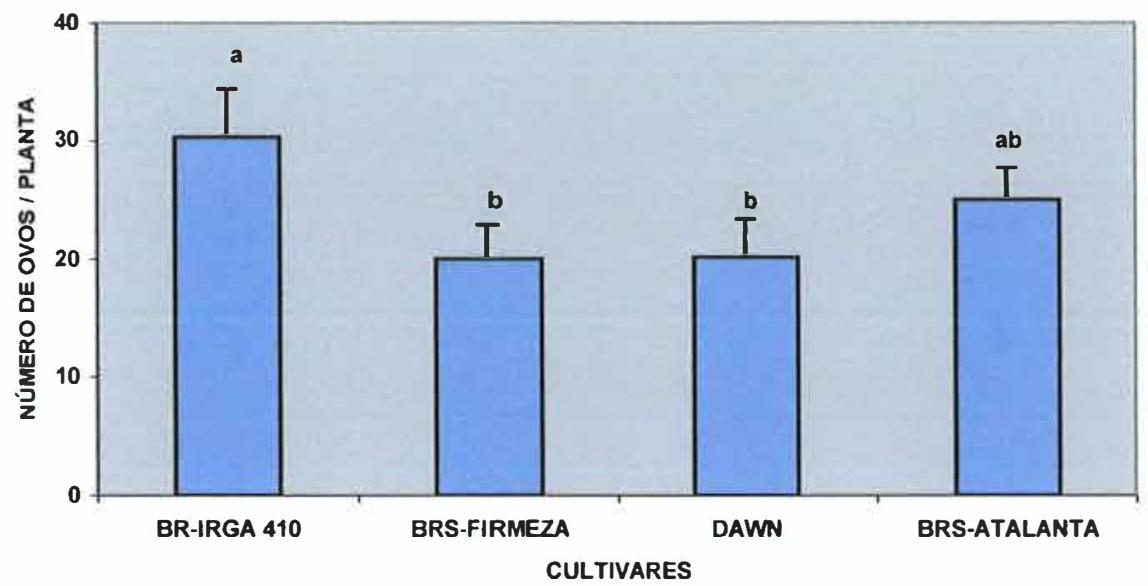

B

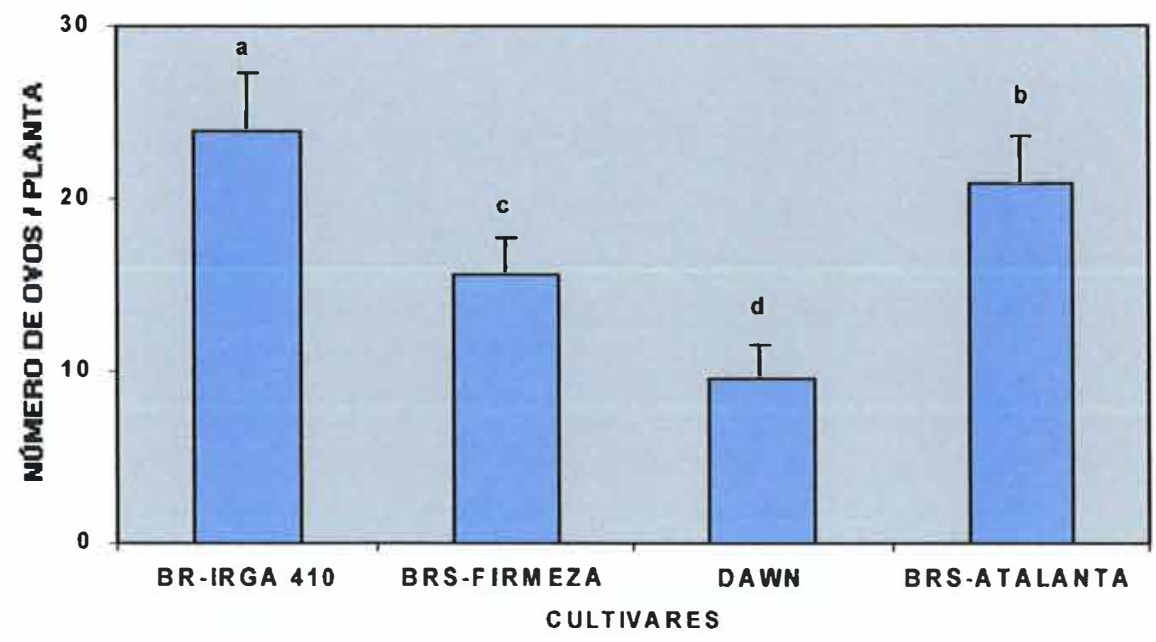

Figura 9. Número de ovos por planta de Oryzophagus oryzae, em cultivares de arroz irrigado, 30 dias após a emergência das plantas. Experimentos com (A) e sem (B) chance de escolha. Pelotas, RS, $1997 / 98$ e 1998/99. Médias ( \pm EP) seguidas por letras distintas diferem pelo teste de Tukey $(\mathrm{P} \leq 0,05)$. 
Tabela 3. Coeficientes de correlação linear (r) entre o número de ovos de Oryzophagus oryzae e a porcentagem de elementos químicos da parte aérea da planta e folhas lesionadas por adultos em cultivares de arroz irrigado, 30 dias após a emergência das plantas. Experimentos com e sem chance de escolha. Pelotas, RS, $1997 / 98$ e 1998/99.

\begin{tabular}{|c|c|c|c|c|c|c|}
\hline \multicolumn{3}{|c|}{ Combinações de Variáveis } & \multicolumn{2}{|c|}{ Com Chance } & \multicolumn{2}{|c|}{ Sem Chance } \\
\hline & & & $\mathrm{N}^{1}$ & $\mathbf{r}$ & $\mathbf{N}^{1}$ & $\mathbf{r}$ \\
\hline Ovos/planta & $\mathrm{x}$ & Nitrogênio & 4 & $0,807^{*}$ & 4 & $0,802^{*}$ \\
\hline Ovos/planta & $\mathrm{x}$ & Lignina & 4 & $-0,224$ & 4 & 0,201 \\
\hline Ovos/planta & $\mathrm{x}$ & Sílica & 4 & $-0,733^{*}$ & 4 & $-0,742^{*}$ \\
\hline Ovos/planta & $\mathrm{x}$ & Fósforo & 4 & 0,571 & 4 & $0,807^{*}$ \\
\hline Ovos/planta & $\mathrm{x}$ & Cálcio & 4 & $0,743^{*}$ & 4 & $0,836^{*}$ \\
\hline Ovos/planta & $\mathbf{x}$ & Magnésio & 4 & 0,412 & 4 & 0,716 \\
\hline Ovos/planta & $\mathrm{x}$ & Potássio & 4 & $0,920^{*}$ & 4 & $0,817^{*}$ \\
\hline Ovos/planta & $\mathrm{x}$ & Folhas lesionadas & 4 & 0,689 & 4 & $0,754^{*}$ \\
\hline
\end{tabular}

${ }^{T}$ Número de combinações entre variáveis.

"Significativo pelo teste " $t$ " a $1 \%(r \geq 0,917), 5 \%(r \geq 0,811)$ e $10 \%(r \geq 0,729)$.

aérea da planta, em determinadas condições o efeito é favorável (Mishra \& Misra, 1992; Salim \& Saxena, 1991 e Samalo et al., 1991) e, em outras, desfavorável (Chen et al., 1994; Narayanasamy et al., 1976; Subbarao \& Perraju, 1976 e Sudhakar et al., 1991) ao ataque de insetos. Portanto, particularidades do hábito e época de alimentação e de oviposição do inseto na planta, e o método de quantificação destes nutrientes, devem ser observadas. 


\subsubsection{Fase larval}

\subsubsection{Número de larvas}

O número de larvas de $O$. oryzae foi significativamente diferente nas cultivares de arroz irrigado, para as condições com e sem chance de escolha do hospedeiro. Em ambas as condições, a cultivar BR-IRGA 410 apresentou maior infestação larval. Porém as demais cultivares, nos experimentos com chance de escolha, não apresentaram diferença significativa, enquanto nos experimentos sem chance o número de larvas em 'BRS-FIRMEZA' e 'Dawn' foi menor que em 'BRSATALANTA' (Figura 10 A e B).

O teor de elementos químicos nas raízes das quatro cultivares de arroz, quantificados $30 \mathrm{DAE}$, diferiu significativamente somente em relação à sílica nos experimentos com e sem chance de escolha (Tabela 4). Aos 55 DAE, foram observadas diferenças em relação à sílica, em ambos os experimentos, e cálcio e magnésio, em experimentos com e sem chance, respectivamente (Tabela 5). Maiores teores de sílica foram quantificados na cultivar Dawn e menores teores de cálcio e magnésio, em 'Dawn' e 'BRS FIRMEZA', respectivamente.

Coeficientes de correlação linear entre níveis de elementos químicos da parte aérea da planta e número de larvas foram positivos para os teores de nitrogênio e potássio, nos experimentos com chance (Tabela 6) e para nitrogênio, fósforo, potássio e cálcio, nos experimentos sem chance (Tabela 7). O número de larvas foi negativamente correlacionado com o teor de sílica na parte aérea da planta, em ambas as condições de experimentação (Tabelas 6 e 7).

Considerando que, após a eclosão, as larvas de $O$. oryzae permanecem, em média, cerca de 1,5 dias alimentando-se das paredes dos aerênquimas foliares, antes de deslocaram-se para as raízes das plantas (Prando, 1999), os elementos químicos presentes na parte aérea da planta podem afetar a sobrevivência larval. É provável que isto tenha ocorrido devido à sílica presente na parte aérea da planta, cuja concentração apresentou correlação negativa com a população de larvas. 
A

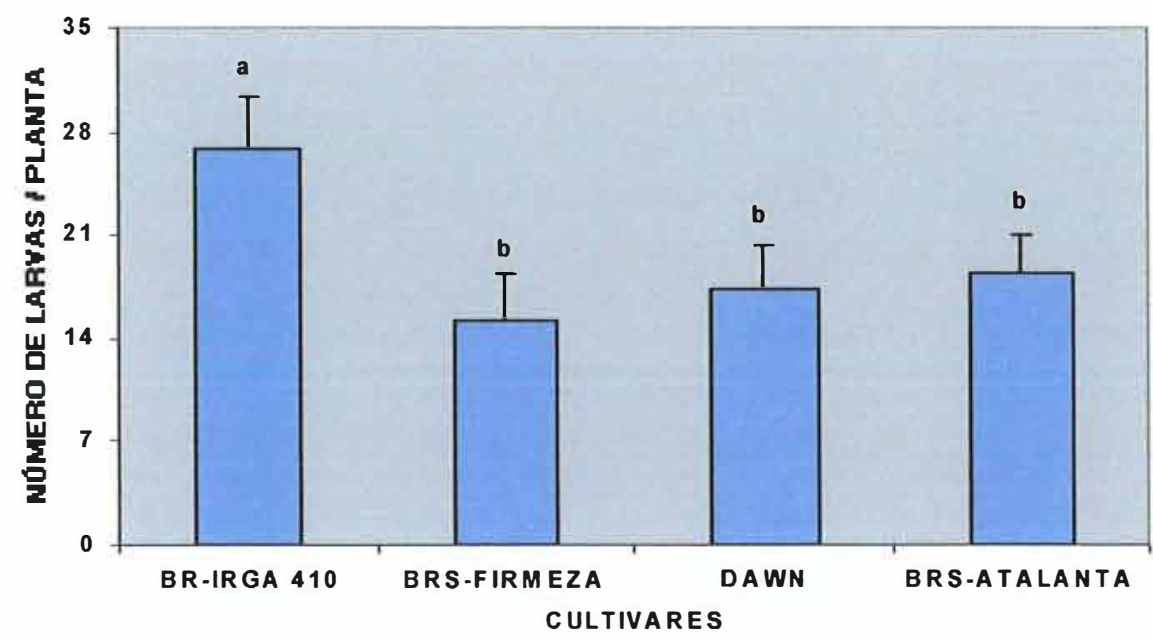

B

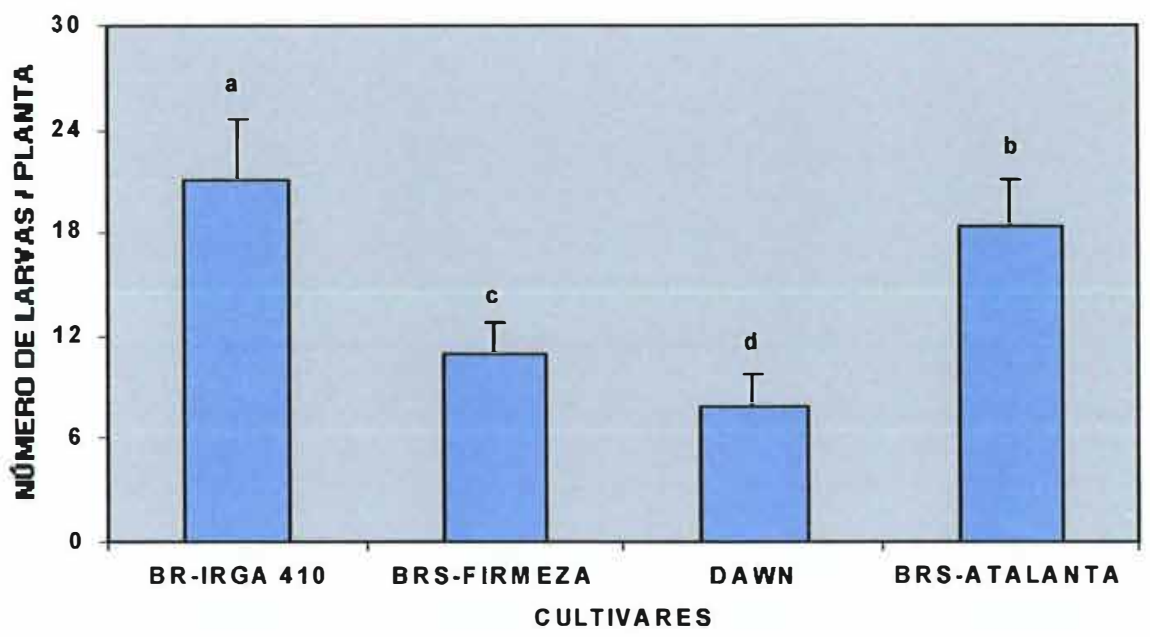

Figura 10. Número de larvas por planta de Oryzophagus oryzae, em cultivares de arroz irrigado, 55 dias após a emergência das plantas. Experimentos com (A) e sem (B) chance de escolha. Pelotas, RS, $1997 / 98$ e 1998/99. Médias ( \pm EP) seguidas por letras distintas diferem pelo teste de Tukey $(\mathrm{P} \leq 0,05)$. 
Nas raízes de cultivares de arroz, as larvas de $O$. oryzae podem ter sua sobrevivência e desenvolvimento afetados pelos elementos químicos presentes neste órgão da planta, durante o todo o período que permanecem sẹ alimentando. Desta forma, os teores de fósforo e sílica, $30 \mathrm{DAE}$, em ambas as condições de experimentação, apresentaram correlação positiva e negativa com o número de larvas, respectivamente (Tabelas 6 e 7). Aos 55 DAE, o número de larvas por planta foi correlacionado positivamente com os teores de lignina, nas duas condições de experimentação, e com potássio e magnésio na condição de com e sem chance de escolha, respectivamente, enquanto com sílica (correlação negativa) apenas na condição de com chance (Tabelas 6 e 7).

A exemplo do que ocorreu com a alimentação de adultos de $O$. oryzae (item 4.1.1.1), o efeito da sílica sobre a população larval evidenciou o potencial antibiótico deste nutriente na alimentação de espécies de insetos-pragas, principalmente as de hábito mastigador (Kim \& Heirichs, 1982; Salim \& Saxena, 1992; Savant et al., 1994; Sujatha et al., 1987; Subbarao \& Perraju, 1976 e Yoshida, 1975), pelo desgaste das mandíbulas, provocado pelo efeito abrasivo (Djamin \& Pathak, 1967; Dravé \& Lauge, 1978; Nakano et al., 1961 e Ramachandran \& Khan, 1991).

O efeito positivo do nitrogênio sobre a população larval de $O$. oryzae, corrobora com resultados obtidos com Lissorhoptrus oryzophilus (Bowling, 1963b e Stout et al., 1998) e L. brevirostris (Meneses \& Elizalde, 1980). Apesar de controversa, a associação positiva do número de larvas com o teor de fósforo, cálcio, magnésio e potássio, também foi obtida com outras espécies pragas de arroz (Mishra \& Misra, 1993; Salim \& Saxena, 1991 e Samalo et al., 1991). A correlação positiva entre o número de larvas e o teor de lignina nas raízes somente $55 \mathrm{DAE}$, é explicado pela alta taxa de lignificação destas após o dano provocado pelo inseto devido sua alimentação sobre este órgão da planta (Martins \& Terres, 1995).

Os números de ovos e de larvas de $O$. oryzae foram positivamente correlacionados entre si nos experimentos com e sem chance de escolha, enquanto os números de larvas e folhas lesionadas somente foram correlacionadas na condição sem chance de escolha (Tabelas 6 e 7). Tal comportamento corrobora com observações 
Tabela 4. Porcentagem de elementos químicos nas raízes de cultivares de arroz irrigado, 30 dias após a emergência das plantas. Experimento $\operatorname{com}^{1}$ e $\operatorname{sem}^{2}$ chance de escolha. Pelotas, RS, $1997 / 98$ e 1998/99.

\begin{tabular}{|c|c|c|c|c|c|}
\hline \multirow{2}{*}{$\begin{array}{l}\text { Elementos } \\
\text { Químicos }\end{array}$} & \multicolumn{4}{|c|}{ Cultivares } & \multirow[t]{2}{*}{ C.V. (\%) } \\
\hline & BR-IRGA 410 & BRS-FIRMEZA & $\overline{\text { DAWN }}$ & BRS-ATALANTA & \\
\hline Nitrogênio & $1,28 \pm 0,04 \mathrm{a}$ & $1,24 \pm 0,05 \mathrm{a}$ & $1,24 \pm 0,06 \mathrm{a}$ & $1,19 \pm 0,07 a$ & 3,4 \\
\hline Nitrogênio $^{2}$ & $1,29 \pm 0,06 \mathrm{a}$ & $1,25 \pm 0,03 \mathrm{a}$ & $1,23 \pm 0,04 \mathrm{a}$ & $1,19 \pm 0,05 \mathrm{a}$ & 5,1 \\
\hline Sílica $^{1}$ & $1,04 \pm 0,13 b$ & $1,96 \pm 0,18 a$ & $2,03 \pm 0,19 a$ & $1,31 \pm 0,14 b$ & 3,9 \\
\hline Sílica $^{2}$ & $1,01 \pm 0,14 b$ & $1,93 \pm 0,18 a$ & $2,01 \pm 0,18 \mathrm{a}$ & $1,28 \pm 0,15 b$ & 4,3 \\
\hline Lignina $^{1}$ & $2,84 \pm 0,23 \mathrm{a}$ & $2,35 \pm 0,15 a$ & $2,87 \pm 0,33 a$ & $2,83 \pm 0,24 \mathrm{a}$ & 4,7 \\
\hline Lignina $^{2}$ & $2,75 \pm 0,31 \mathrm{a}$ & $2,26 \pm 0,17 \mathrm{a}$ & $2,77 \pm 0,58 \mathrm{a}$ & $2,75 \pm 0,29 a$ & 5,3 \\
\hline Fósforo ${ }^{1}$ & $0,46 \pm 0,03 \mathrm{a}$ & $0,42 \pm 0,02 \mathrm{a}$ & $0,41 \pm 0,01 \mathrm{a}$ & $0,42 \pm 0,01 \mathrm{a}$ & 3,2 \\
\hline Fósforo $^{2}$ & $0,47 \pm 0,01 \mathrm{a}$ & $0,43 \pm 0,02 \mathrm{a}$ & $0,42 \pm 0,03 \mathrm{a}$ & $0,43 \pm 0,01 \mathrm{a}$ & 2,5 \\
\hline Cálcio ${ }^{1}$ & $0,11 \pm 0,03 \mathrm{a}$ & $0,10 \pm 0,02 \mathrm{a}$ & $0,10 \pm 0,02 \mathrm{a}$ & $0,13 \pm 0,02 \mathrm{a}$ & 2,9 \\
\hline Cálcio $^{2}$ & $0,12 \pm 0,02 \mathrm{a}$ & $0,11 \pm 0,01 \mathrm{a}$ & $0,11 \pm 0,01 \mathrm{a}$ & $0,14 \pm 0,01$ a & 3,1 \\
\hline Magnésio' & $0,14 \pm 0,01 \mathrm{a}$ & $0,13 \pm 0,02 \mathrm{a}$ & $0,15 \pm 0,01 \mathrm{a}$ & $0,17 \pm 0,02 a$ & 2,6 \\
\hline Magnésio $^{2}$ & $0,13 \pm 0,02 a$ & $0,12 \pm 0,03 a$ & $0,14 \pm 0,01 \mathrm{a}$ & $0,16 \pm 0,03 a$ & 3,0 \\
\hline Potássio $^{1}$ & $1,00 \pm 0,05 a$ & $0,98 \pm 0,08 a$ & $1,01 \pm 0,09 a$ & $1,02 \pm 0,05 a$ & 2,3 \\
\hline Potássio $^{2}$ & $1,02 \pm 0,04 \mathrm{a}$ & $0,99 \pm 0,06 a$ & $1,03 \pm 0,03 \mathrm{a}$ & $1,05 \pm 0,03 \mathrm{a}$ & 2,4 \\
\hline
\end{tabular}

Médias $( \pm E P)$ seguidas por letras distintas na mesma linha diferem pelo teste de Tukey $(\mathrm{P} \leq 0,05)$.

realizadas por Prando (1999), em que as larvas, após a eclosão e saída da bainha foliar, migram para as raízes da mesma planta. Todavia, a não correlação entre o número de larvas e folhas lesionadas na condição de com chance de escolha, se deve a não obrigatoriedade da alimentação e postura ocorrerem em igual intensidade na mesma planta, já que nestas condições o adulto possui opções para selecionar mais de um hospedeiro (Botton, 1996).

\subsubsection{Peso de larvas}

Mesmo não ocorrendo diferença significativa quanto ao peso de larvas de $O$. oryzae nas cultivares de arroz irrigado avaliadas (Figura 11 A e B), foram 
observadas correlações significativas com o teor de elementos químicos nas raízes 55 DAE. Para os teores de potássio e sílica, correlações positivas e negativas, respectivamente, ocorreram em ambas as condições de avaliação, enquanto que para os teores de lignina e fósforo, houve correlação (positiva) somente nos experimentos com e sem chance de escolha, respectivamente (Tabela 8).

Tabela 5. Porcentagem de elementos químicos nas raízes de cultivares de arroz irrigado, 55 dias após a emergência das plantas. Experimentos $\operatorname{com}^{1}$ e sem ${ }^{2}$ chance de escolha. Pelotas, RS, $1997 / 98$ e 1998/99.

\begin{tabular}{|c|c|c|c|c|c|}
\hline \multirow{2}{*}{$\begin{array}{l}\text { Elementos } \\
\text { Químicos }\end{array}$} & \multicolumn{4}{|c|}{ Cultivares } & \multirow[t]{2}{*}{$\overline{C . V .(\%)}$} \\
\hline & BR-IRGA 410 & BRS-FIRMEZA & DAWN & BRS-ATALANTA & \\
\hline Nitrogênio ${ }^{-1}$ & $0,83 \pm 0,04 \mathrm{a}$ & $0,87 \pm 0,05 a$ & $0,77 \pm 0,06 \mathrm{a}$ & $0,84 \pm 0,07 a$ & 4,9 \\
\hline Nitrogênio $^{2}$ & $0,87 \pm 0,04 \mathrm{a}$ & $0,99 \pm 0,05 \mathrm{a}$ & $0,84 \pm 0,06 \mathrm{a}$ & $0,87 \pm 0,07 \mathrm{a}$ & 2,7 \\
\hline Sílica $^{1}$ & $1,49 \pm 0,10 b$ & $1,98 \pm 0,11 \mathrm{a}$ & $2,12 \pm 0,15 a$ & $1,90 \pm 0,09 a$ & 4,5 \\
\hline Sílica $^{2}$ & $1,41 \pm 0,11 b$ & $1,96 \pm 0,17 \mathrm{a}$ & $2,11 \pm 0,16 \mathrm{a}$ & $2,05 \pm 0,12 \mathrm{a}$ & 3,8 \\
\hline Lignina $^{1}$ & $6,42 \pm 0,60 \mathrm{a}$ & $5,35 \pm 0,50 \mathrm{a}$ & $5,52 \pm 0,71 \mathrm{a}$ & $5,75 \pm 0,64 \mathrm{a}$ & 5,2 \\
\hline Lignina $^{2}$ & $6,30 \pm 0,51 \mathrm{a}$ & $5,22 \pm 0,47 a$ & $5,41 \pm 0,54 \mathrm{a}$ & $5,63 \pm 0,39 a$ & 5,7 \\
\hline Fósforo ${ }^{1}$ & $0,47 \pm 0,03 \mathrm{a}$ & $0,47 \pm 0,02 \mathrm{a}$ & $0,46 \pm 0,01 \mathrm{a}$ & $0,46 \pm 0,01 \mathrm{a}$ & 2,3 \\
\hline Fósforo ${ }^{2}$ & $0,47 \pm 0,01^{\mathrm{a}}$ & $0,46 \pm 0,02 \mathrm{a}$ & $0,45 \pm 0,03 \mathrm{a}$ & $0,44 \pm 0,01 \mathrm{a}$ & 3,0 \\
\hline Cálcio ${ }^{1}$ & $0,12 \pm 0,02 \mathrm{a}$ & $0,10 \pm 0,02 a b$ & $0,09 \pm 0,01 \mathrm{~b}$ & $0,14 \pm 0,02 \mathrm{a}$ & 3,7 \\
\hline Cálcio $^{2}$ & $0,07 \pm 0,02 \mathrm{a}$ & $0,07 \pm 0,01 \mathrm{a}$ & $0,06 \pm 0,01 \mathrm{a}$ & $0,08 \pm 0,01 \mathrm{a}$ & 4,6 \\
\hline Magnésio $^{1}$ & $0,11 \pm 0,01 \mathrm{a}$ & $0,10 \pm 0,02 \mathrm{a}$ & $0,09 \pm 0,01 \mathrm{a}$ & $0,12 \pm 0,02 \mathrm{a}$ & 5,4 \\
\hline Magnésio $^{2}$ & $0,13 \pm 0,02 \mathrm{a}$ & $0,08 \pm 0,02 b$ & $0,10 \pm 0,02 \mathrm{ab}$ & $0,13 \pm 0,02 \mathrm{a}$ & 3,5 \\
\hline Potássio ${ }^{1}$ & $0,61 \pm 0,05 \mathrm{a}$ & $0,58 \pm 0,08 a$ & $0,59 \pm 0,09 \mathrm{a}$ & $0,57 \pm 0,05 \mathrm{a}$ & 2,1 \\
\hline Potássio $^{2}$ & $0,61 \pm 0,04 \mathrm{a}$ & $0,59 \pm 0,06 \mathrm{a}$ & $0,59 \pm 0,03 \mathrm{a}$ & $0,58 \pm 0,03 \mathrm{a}$ & 2,1 \\
\hline
\end{tabular}


Tabela 6. Coeficientes de correlação linear (r) entre o número de larvas de Oryzophagus oryzae e a porcentagem de elementos químicos na parte aérea da planta, 30 $(r)^{1}$ e raízes, $30 \quad(r)^{2}$ e $55(r)^{3}$ dias após a emergência das plantas; folhas lesionadas e número de ovos por planta em cultivares de arroz irrigado. Experimentos com chance de escolha. Pelotas, RS, 1997/98 e 1998/99.

\begin{tabular}{lclcccc}
\hline Combinações de Variáveis & $\mathbf{N}^{1}$ & $\mathbf{( r )}^{\mathbf{1}}$ & $\mathbf{( r )}^{2}$ & $\mathbf{( r )}^{3}$ \\
\hline Larvas/planta & $\mathrm{x}$ & Nitrogênio & 4 & $0,925^{*}$ & 0,537 & 0,092 \\
Larvas/planta & $\mathrm{x}$ & Lignina & 4 & $-0,232$ & 0,533 & $0,989^{*}$ \\
Larvas/planta & $\mathrm{x}$ & Sílica & 4 & $-0,746^{*}$ & $-0,834^{*}$ & $-0,921^{*}$ \\
Larvas/planta & $\mathrm{x}$ & Fósforo & 4 & 0,263 & $0,908^{*}$ & 0,305 \\
Larvas/planta & $\mathrm{x}$ & Cálcio & 4 & 0,559 & 0,186 & 0,363 \\
Larvas/planta & $\mathrm{x}$ & Magnésio & 4 & 0,076 & 0,115 & 0,401 \\
Larvas/planta & $\mathrm{x}$ & Potássio & 4 & $0,872^{*}$ & 0,261 & $0,808^{*}$ \\
Larvas/planta & $\mathrm{x}$ & Folhas lesionadas & 4 & & 0,519 & \\
Larvas/planta & $\mathrm{x}$ & Ovos/planta & 4 & & $0,937^{*}$ & \\
\hline
\end{tabular}

Túmero de combinações entre variáveis.

"Significativo pelo teste " $t$ " a $1 \%(r \geq 0,917), 5 \%(r \geq 0,811)$ e $10 \%(r \geq 0,729)$.

Larvas de $O$. oryzae alimentadas em raízes de plantas de arroz com maior teor de sílica, tiveram seu crescimento e desenvolvimento afetados negativamente, sendo evidenciado um efeito negativo no desenvolvimento de insetos mastigadores, devido ao desgaste excessivo das mandíbulas, causado pela sua ação abrasiva. Além do efeito mecânico, a sílica dificulta a digestibilidade do alimento ingerido pelo inseto, reduzindo a assimilação de nutrientes (Djamin \& Patak, 1967; Martins et al.; 1977 e Mishra \& Misra, 1992).

O efeito positivo de potássio e fósforo no desenvolvimento larval de $O$. oryzae pode estar associado ao fato destes serem responsáveis pelos aminoácidos, proteínas e gorduras da planta, uma vez que o balanço destas substâncias e o valor nutritivo afetam o ataque de insetos (Hirano, 1964 e Panizzi \& Parra, 1991). A 
associação positiva entre o desenvolvimento larval e o teor de lignina, deve-se a maior taxa de lignificação dos tecidos posteriormente ao ataque do inseto (Martins et al., 1995). Em hipótese, larvas mais desenvolvidas (mais pesadas) provocaram maior dano às raízes e consequente aumento da taxa de lignina.

Tabela 7. Coeficientes de correlação linear (r) entre o número de larvas de Oryzophagus oryzae e a porcentagem de elementos químicos na parte aérea da planta, 30 DAE $(r)^{1}$ e raízes, $30(r)^{2}$ e 55 DAE $(r)^{3}$, folhas lesionadas e número de ovos por planta em cultivares de arroz irrigado. Experimentos sem chance de escolha. Pelotas, RS, 1997/98 e 1998/99.

\begin{tabular}{llllccc}
\hline Combinaçóes de & Variáveis & $\mathbf{N}^{1}$ & $(\mathbf{r})^{1}$ & $\mathbf{( r )}^{\mathbf{2}}$ & $\mathbf{( r )}^{\mathbf{3}}$ \\
\hline Larvas/planta & $\mathrm{x}$ & Nitrogênio & 4 & $0,918^{*}$ & 0,103 & 0,189 \\
Larvas/planta & $\mathrm{x}$ & Lignina & 4 & $-0,316$ & 0,364 & $0,842^{*}$ \\
Larvas/planta & $\mathrm{x}$ & Sílica & 4 & $-0,863^{*}$ & $-0,988^{*}$ & $-0,714$ \\
Larvas/planta & $\mathrm{x}$ & Fósforo & 4 & $0,805^{*}$ & $0,798^{*}$ & 0,232 \\
Larvas/planta & $\mathrm{x}$ & Cálcio & 4 & $0,818^{*}$ & 0,521 & 0,491 \\
Larvas/planta & $\mathrm{x}$ & Magnésio & 4 & 0,689 & 0,274 & $0,824^{*}$ \\
Larvas/planta & $\mathrm{x}$ & Potássio & 4 & $0,862^{*}$ & 0,163 & 0,316 \\
Larvas/planta & $\mathrm{x}$ & Folhas lesionadas & 4 & & $0,898^{*}$ & \\
Larvas/planta & $\mathrm{x}$ & Ovos/planta & 4 & & $0,979^{*}$ &
\end{tabular}

Túmero de combinações entre variáveis.

"Significativo pelo teste " $t$ " a $1 \%(r \geq 0,917), 5 \%(r \geq 0,811)$ e $10 \%(r \geq 0,729)$. 


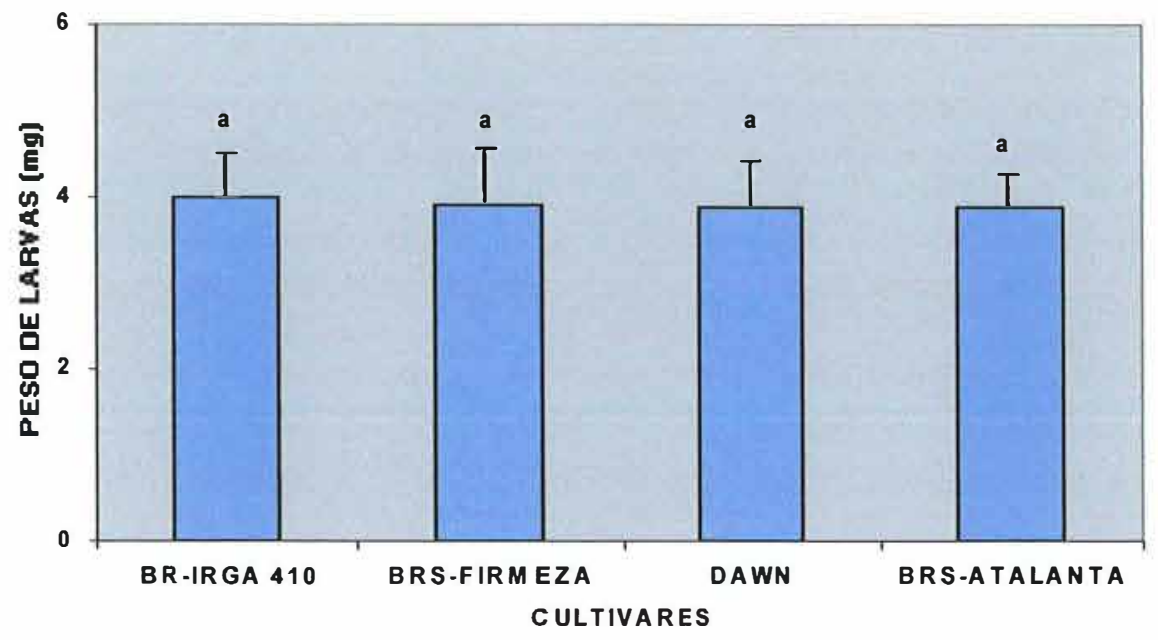

B

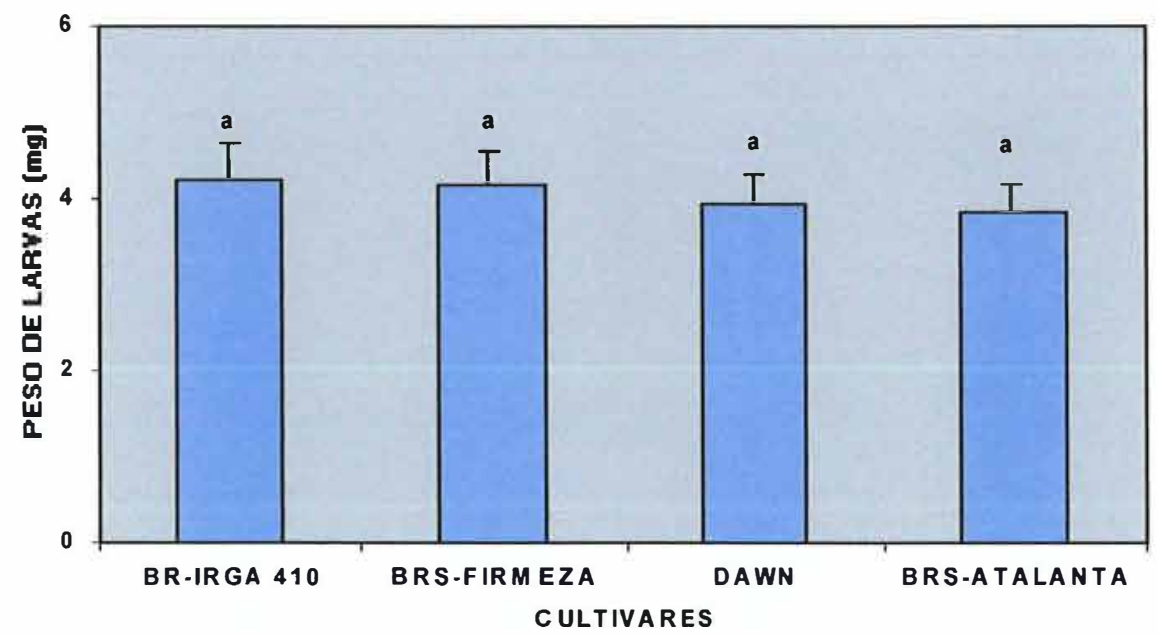

Figura 11. Peso (mg) individual de larvas de Oryzophagus oryzae, em cultivares de arroz irrigado, 55 dias após a emergência das plantas. Experimentos com (A) e sem (B) chance de escolha. Pelotas, RS, $1997 / 98$ e 1998/99. Médias ( \pm EP) seguidas por letras distintas diferem pelo teste de Tukey $(\mathrm{P} \leq 0,05)$. 
Tabela 8. Coeficientes de correlação linear (r) entre peso (mg) de larvas de Oryzophagus oryzae e a porcentagem de elementos químicos das raízes, em cultivares de arroz irrigado, 55 dias após a emergência das plantas. Experimentos com e sem chance de escolha. Pelotas, RS, 1997/98 e 1998/99.

\begin{tabular}{|c|c|c|c|c|c|c|}
\hline \multicolumn{3}{|c|}{ Combinações de Variáveis } & \multicolumn{2}{|c|}{ Com Chance } & \multicolumn{2}{|c|}{ Sem Chance } \\
\hline & & & $\mathrm{N}^{1}$ & $\overline{\mathbf{r}}$ & $\mathbf{N}^{1}$ & $\overline{\mathbf{r}}$ \\
\hline Peso de larvas & $\mathrm{x}$ & Nitrogênio & 4 & 0,164 & 4 & 0,513 \\
\hline Peso de larvas & $\mathrm{x}$ & Lignina & 4 & $0,829^{*}$ & 4 & 0,341 \\
\hline Peso de larvas & $\mathrm{x}$ & Sílica & 4 & $-0,874^{*}$ & 4 & $-0,749^{*}$ \\
\hline Peso de larvas & $\mathrm{x}$ & Fósforo & 4 & 0,701 & 4 & $0,904^{*}$ \\
\hline Peso de larvas & $\mathrm{x}$ & Cálcio & 4 & 0,129 & 4 & $-0,191$ \\
\hline Peso de larvas & $\mathrm{x}$ & Magnésio & 4 & 0,073 & 4 & $-0,206$ \\
\hline Peso de larvas & $\mathrm{x}$ & Potássio & 4 & $0,837^{*}$ & 4 & $0,799^{*}$ \\
\hline
\end{tabular}

Túmero de combinações entre variáveis.

"Significativo pelo teste " $t$ " a $1 \%(r \geq 0,917), 5 \%(r \geq 0,811)$ e $10 \%(r \geq 0,729)$.

\subsection{Efeito de O. oryzae sobre cultivares de arroz}

\subsubsection{Elementos químicos da planta}

É possível que a alimentação das larvas de $O$. oryzae nas raízes de cultivares de arroz irrigado, resulte na redução do teor dos nutrientes presentes no sistema radicular e parte aérea das plantas. Com a redução do comprimento e volume do sistema radicular provocado pela alimentação das larvas (Carbonari, 1996 e Carbonari et al., 2000), é provável que ocorra menor absorção de nutrientes pelas raízes, refletindo consequentemente na parte aérea da planta. Porém, em função do ciclo de desenvolvimento das cultivares avaliadas, é possível que ocorram diferenças na intensidade da recuperação do sistema radicular danificado pelas larvas. 


\subsubsection{Nitrogênio}

O teor de nitrogênio na parte aérea e sistema radicular reduziu-se com o desenvolvimento da planta. Na primeira avaliação, antes da infestação do inseto, 30 dias após a emergência, não houve diferença significativa entre plantas, da mesma cułtivar, livres e infestadas por $O$. oryzae, evidenciando a homogeneidade da área experimental em relação a este nutriente. Entretanto, após o dano das larvas (55 DAE), a redução do teor do nutriente na parte aérea e raízes da planta foi significativa para a maioria das cultivares, com exceção de 'BRS FIRMEZA', nas raízes. Na colheita das plantas, a redução do teor de nitrogênio foi significativa para todas as cultivares na parte aérea, enquanto nas raízes a significância ficou restrita para 'BR IRGA 410' e 'BRS ATALANTA' (Figura 12 A e B).

Houve correlação positiva entre número de larvas e redução do teor do nutriente na parte aérea das plantas (Tabela 9), 55 dias após a emergência e colheita, e nas raízes (Tabela 10) somente 55 DAE. Com o peso de larvas, a correlação (positiva) com a redução do teor do nutriente na parte aérea da planta, somente ocorreu aos 55 DAE (Tabela 11 e 12). Tais correlações evidenciam o efeito da população e não do tamanho de larvas na redução do teor de nitrogênio da parte aérea e raízes das plantas de arroz. Portanto, a diferença não significativa na redução do teor de nitrogênio na cultivar Dawn, além de estar associada com o menor número de larvas, provavelmente também está relacionada ao maior ciclo de desenvolvimento apresentado por esta cultivar, o que teria possibilitado maior recuperação do sistema radicular danificado pelas larvas e, consequentemente, maior teor do nutriente absorvido.

Cultivares de arroz irrigado com maior ciclo de desenvolvimento apresentam maior capacidade de recuperação do sistema radicular danificado por larvas de O. oryzae, comparadas com as de ciclo curto (Carbonari, et al., 2000 e Martins et al., 1995). 
A

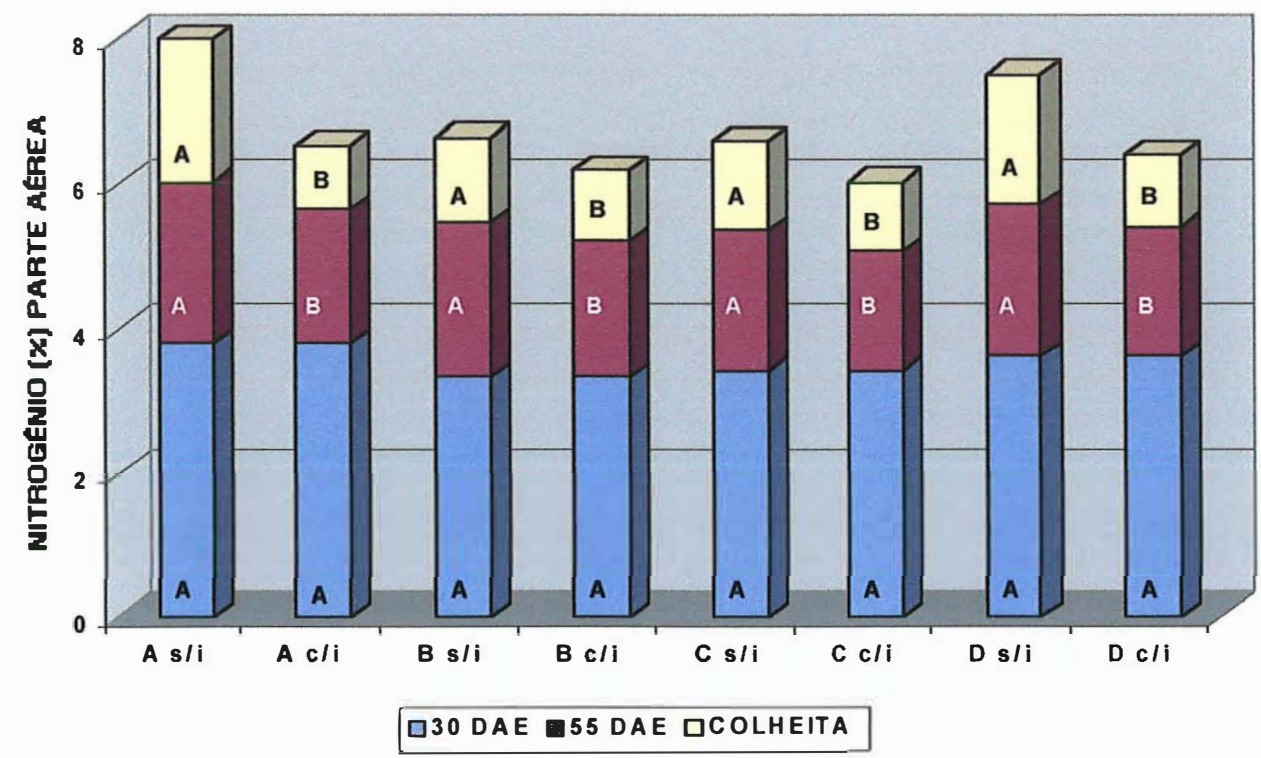

B

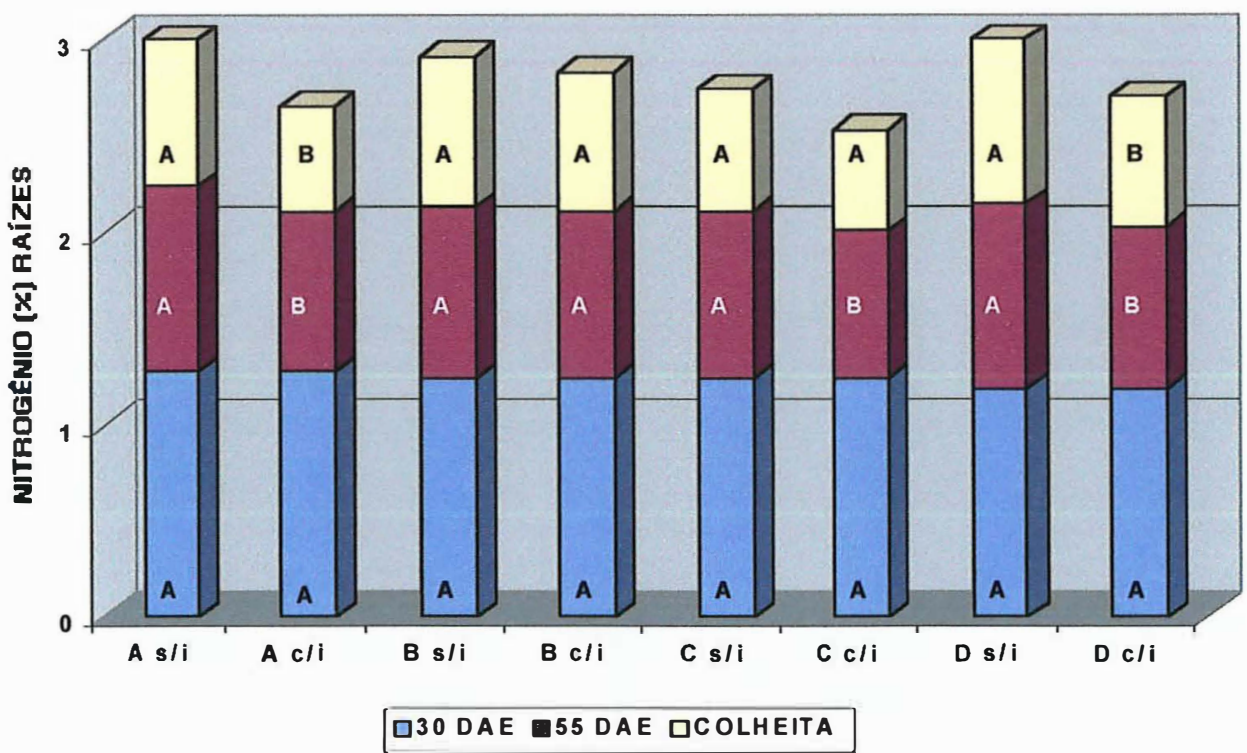

Figura 12. Teor de nitrogênio na parte aérea (A) e raízes (B) de cultivares ${ }^{1}$ de arroz irrigado, livres (s/i) e infestadas (c/i) por Oryzophagus oryzae, durante o ciclo de desenvolvimento da cultura. Pelotas, RS, 1997/98 e 1998/99. Médias seguidas de letras distintas na mesma cultivar e época de avaliação diferem pelo teste de Tukey $(\mathrm{P} \leq 0,05)$.

' (A) BR IRGA 410; (B) BRS FIRMEZA; (C) Dawn; (D) BRS ATALANTA. 
Tabela 9. Coeficientes de correlação linear entre número de larvas de Oryzophagus oryzae e redução (sem e com infestação) na porcentagem de elementos químicos da parte aérea de cultivares de arroz irrigado, 55 dias (r) ${ }^{1}$ após a emergência e na colheita (r) ${ }^{2}$ das plantas. Pelotas, RS, 1997/98 e 1998/99.

\begin{tabular}{lclccc}
\hline Combinações de Variáveis & & $\mathbf{N}^{1}$ & $(\mathbf{r})^{1}$ & $(\mathbf{r})^{2}$ \\
\hline Número de larvas & $\mathrm{x}$ & Nitrogênio & 4 & $0,965^{*}$ & $0,884^{*}$ \\
Número de larvas & $\mathrm{x}$ & Fósforo & 4 & $0,991^{*}$ & $0,730^{*}$ \\
Número de larvas & $\mathrm{x}$ & Potássio & 4 & $0,898^{*}$ & $0,774^{*}$ \\
Número de larvas & $\mathrm{x}$ & Cálcio & 4 & $0,997^{*}$ & $0,916^{*}$ \\
Número de larvas & $\mathrm{x}$ & Magnésio & 4 & 0,709 & 0,678 \\
Número de larvas & $\mathrm{x}$ & Sílica & 4 & 0,451 & 0,097 \\
Número de larvas & $\mathrm{x}$ & Lignina & 4 & 0,169 & $0,781^{*}$ \\
\hline
\end{tabular}

${ }^{\top}$ Número de combinações entre variáveis.

"Significativo pelo teste " $t$ " a $1 \%(r \geq 0,917), 5 \%(r \geq 0,811)$ e $10 \%(r \geq 0,729)$.

Tabela 10. Coeficientes de correlação linear entre número de larvas de Oryzophagus oryzae e redução (sem e com infestação) na porcentagem de elementos químicos das raízes de cultivares de arroz irrigado, 55 dias (r) ${ }^{1}$ após a emergência e na colheita (r) ${ }^{2}$ das plantas. Pelotas, RS, 1997/98 e 1998/99.

\begin{tabular}{lclccc}
\hline Combinações de Variáveis & & $\mathbf{N}^{1}$ & $(\mathbf{r})^{1}$ & $(\mathbf{r})^{2}$ \\
\hline Número de larvas & $\mathrm{x}$ & Nitrogênio & 4 & $0,745^{*}$ & 0,697 \\
Número de larvas & $\mathrm{x}$ & Fósforo & 4 & $0,962^{*}$ & $0,910^{*}$ \\
Número de larvas & $\mathrm{x}$ & Potássio & 4 & $0,971^{*}$ & $0,904^{*}$ \\
Número de larvas & $\mathrm{x}$ & Cálcio & 4 & $0,997^{*}$ & 0,704 \\
Número de larvas & $\mathrm{x}$ & Magnésio & 4 & $0,967^{*}$ & 0,598 \\
Número de larvas & $\mathrm{x}$ & Sílica & 4 & 0,245 & 0,687 \\
Número de larvas & $\mathrm{x}$ & Lignina & 4 & $0,941^{*}$ & $0,836^{*}$ \\
\hline
\end{tabular}

TNúmero de combinações entre variáveis.

"Significativo pelo teste " $\mathrm{t}$ " a $1 \%(r \geq 0,917), 5 \%(r \geq 0,811)$ e $10 \%(r \geq 0,729)$. 
Tabela 11. Coeficientes de correlação linear entre peso de larvas de Oryzophagus oryzae e redução (sem e com infestação) na porcentagem de elementos químicosda parte aérea de cultivares de arroz irrigado, 55 dias (r) ${ }^{1}$ após a emergência e na colheita (r) ${ }^{2}$ das plantas. Pelotas, RS, $1997 / 98$ e 1998/99.

\begin{tabular}{llllll}
\hline Combinações de Variáveis & & $\mathrm{N}^{1}$ & $(\mathbf{r})^{1}$ & $\mathbf{( r}^{\mathbf{2}}$ \\
\hline Peso de larvas & $\mathrm{x}$ & Nitrogênio & 4 & $0,734^{*}$ & 0,623 \\
Peso de larvas & $\mathrm{x}$ & Fósforo & 4 & $0,852^{*}$ & 0,357 \\
Peso de larvas & $\mathrm{x}$ & Potássio & 4 & 0,621 & 0,580 \\
Peso de larvas & $\mathrm{x}$ & Cálcio & 4 & $0,972^{*}$ & $0,763^{*}$ \\
Peso de larvas & $\mathrm{x}$ & Magnésio & 4 & $0,963^{*}$ & 0,578 \\
Peso de larvas & $\mathrm{x}$ & Sílica & 4 & 0,211 & 0,455 \\
Peso de larvas & $\mathrm{x}$ & Lignina & 4 & 0,547 & $0,971^{*}$ \\
\hline
\end{tabular}

Número de combinações entre variáveis.

* Significativo pelo teste $t$ a $1 \%(r \geq 0,917), 5 \%(r \geq 0,811)$ e $10 \%(r \geq 0,729)$.

Tabela 12. Coeficientes de correlação linear entre peso de larvas de Oryzophagus oryzae e redução (sem e com infestação) na porcentagem de elementos químicos das raízes de cultivares de arroz irrigado, 55 dias (r) ${ }^{1}$ após a emergência e na colheita $(r)^{2}$ das plantas. Pelotas, RS, 1997/98 e 1998/99.

\begin{tabular}{llllll}
\hline Combinações de Variáveis & & $\mathbf{N}^{1}$ & $(\mathbf{r})^{\mathbf{I}}$ & $(\mathbf{r})^{2}$ \\
\hline Peso de larvas & $\mathrm{x}$ & Nitrogênio & 4 & 0,639 & 0,617 \\
Peso de larvas & $\mathrm{x}$ & Fósforo & 4 & $0,759^{*}$ & 0,628 \\
Peso de larvas & $\mathrm{x}$ & Potássio & 4 & $0,784^{*}$ & $0,747^{*}$ \\
Peso de larvas & $\mathrm{x}$ & Cálcio & 4 & $0,887^{*}$ & 0,369 \\
Peso de larvas & $\mathrm{x}$ & Magnésio & 4 & $0,972^{*}$ & 0,578 \\
Peso de larvas & $\mathrm{x}$ & Sílica & 4 & 0,262 & 0,503 \\
Peso de larvas & $\mathrm{x}$ & Lignina & 4 & $0,791^{*}$ & 0,599
\end{tabular}

Túmero de combinações entre variáveis.

"Significativo pelo teste " $t$ " a $1 \%(r \geq 0,917), 5 \%(r \geq 0,811)$ e $10 \%(r \geq 0,729)$. 


\subsubsection{Fósforo}

Os teores de fósforo na parte aérea e nas raízes não diferiram em plantas da mesma cultivar, livres e infestadas pelo inseto, na avaliação feita 30 DAE. Entretanto, $55 \mathrm{DAE}$, após o dano provocado pelas larvas, na parte aérea e raízes das cultivares $\mathrm{BR}$ IRGA 410 e BRS ATALANTA e somente nas raizes da Dawn, houve redução significativa. Na colheita, a diferença foi significativa para os teores da parte aérea e raízes das cultivares BR IRGA 410 e BRS ATALANTA (Figura 13 A e B). Correlação positiva foi observada entre o número de larvas e a redução do teor do nutriente tanto na parte aérea como nas raízes, em ambas as épocas de avaliação após o dano do inseto (Tabelas 9 e 10). Porém, para o peso de larvas, a correlação foi significativa apenas 55 DAE, tanto para a parte aérea como para as raízes (Tabelas 11 e 12).

De forma similar ao teor de nitrogênio, o número de larvas reduziu significativamente o teor de fósforo nas plantas. Porém neste caso, o peso de larvas também foi associado à redução, pelo menos até 55 DAE. O maior número de larvas, somado ao menor ciclo das plantas das cultivares BR-IRGA 410 e BRS ATALANTA, refletiram na não recuperação do teor deste nutriente, nas plantas atacadas pelo inseto. Comportamento inverso foi constatado na cultivar Dawn. Já para a cultivar BRS FIRMEZA, a diferença entre plantas livres e com ataque do inseto permaneceu não significativa. 
A

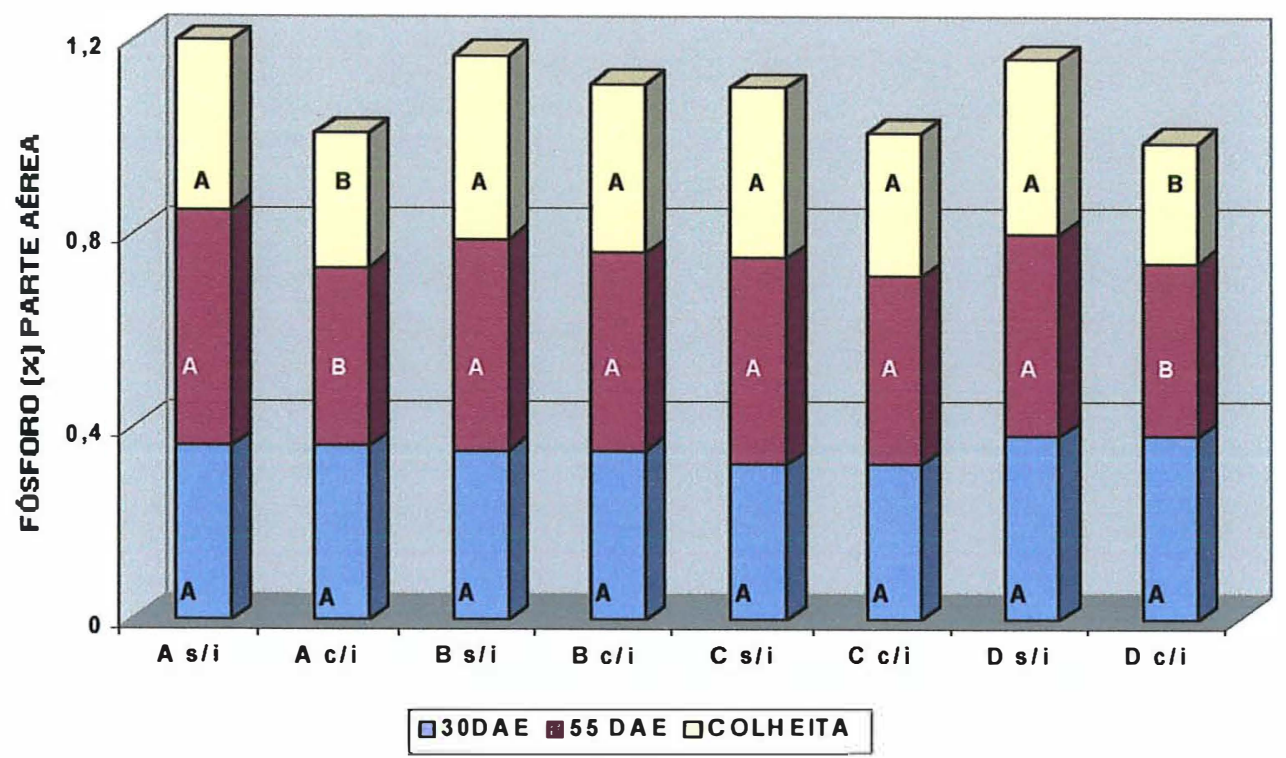

B

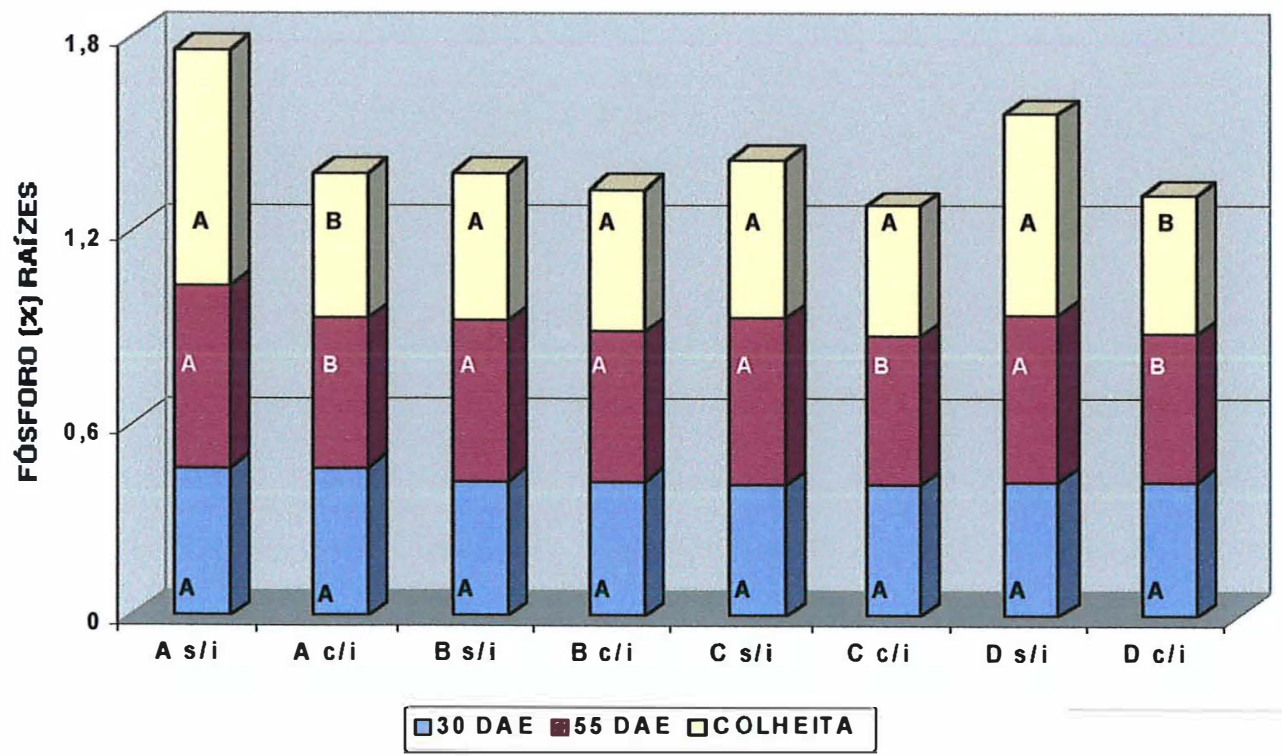

Figura 13. Teor de fósforo na parte aérea (A) e raízes (B) de plantas de cultivares ${ }^{1}$ de arroz irrigado, livres (s/i) e infestadas (c/i) por Oryzophagus oryzae, durante o ciclo de desenvolvimento da cultura. Pelotas, RS, 1997/98 e 1998/99. Médias seguidas de letras distintas na mesma cultivar e época de avaliação diferem pelo teste de Tukey $(\mathrm{P} \leq 0,05)$.

' (A) BR IRGA 410; (B) BRS FIRMEZA; (C) Dawn; (D) BRS ATALANTA. 


\subsubsection{Potássio}

Os teores de potássio na parte aérea e raízes não diferiram em plantas da mesma cultivar livres e infestadas pelo inseto, $30 \mathrm{DAE}$, e após o dano provocado pelas larvas às raízes, $55 \mathrm{DAE}$. Porém na colheita, as quatro cultivares apresentaram diferença significativa no teor do nutriente nas raízes de plantas livres e infestadas, e somente em 'Dawn' não houve diferença em relação à parte aérea (Figura $14 \mathrm{~A} \mathrm{e} \mathrm{B).}$ Mesmo não havendo diferença significativa no teor do nutriente entre plantas livres e infestadas, 55 DAE, a redução deste foi positivamente correlacionada com o número de larvas, e com o peso (somente nas raízes) destas, em ambas as épocas de avaliação após o dano do inseto (Tabelas 9 a 12). O menor número de larvas e o maior ciclo das plantas da cultivar Dawn podem explicar a menor redução do teor deste nutriente, comparado com as demais.

Os teores de potássio nas raízes e parte aérea da planta apresentam uma variação caracteristicamente distinta. Enquanto no sistema radicular o teor deste nutriente decresce com a idade da planta, na parte aérea há um incremento durante a fase vegetativa e decréscimo na reprodutiva (Figura 14). O conhecimento das diferentes concentrações dos nutrientes nos diversos órgãos da planta, durante o seu ciclo de desenvolvimento, são relevantes na associação com ataque e dano de pragas.

\subsubsection{Cálcio}

A exemplo dos demais nutrientes, na avaliação anterior ao ataque do inseto, $30 \mathrm{DAE}$, teores de cálcio na parte aérea e raízes não diferiram em plantas da mesma cultivar. Entretanto $55 \mathrm{DAE}$, após o dano provocado pelas larvas, na parte aérea e raízes da cultivar BR IRGA 410 e somente nas raizes da 'BRS ATALANTA', houve redução significativa, no teor deste nutriente. $\mathrm{Na}$ colheita, a diferença foi significativa para os teores da parte aérea e raízes das cultivares BR IRGA 410 e BRS ATALANTA, 
A

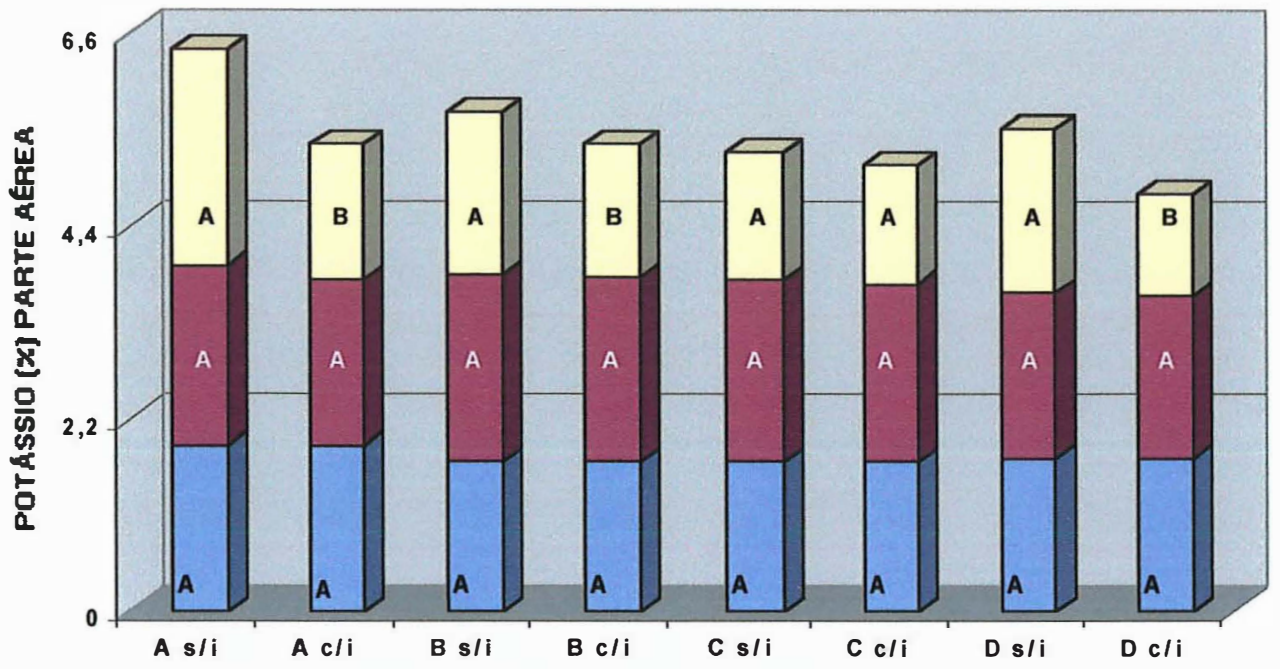

Q30 DAE G55 DAE DCOLHEITA

B

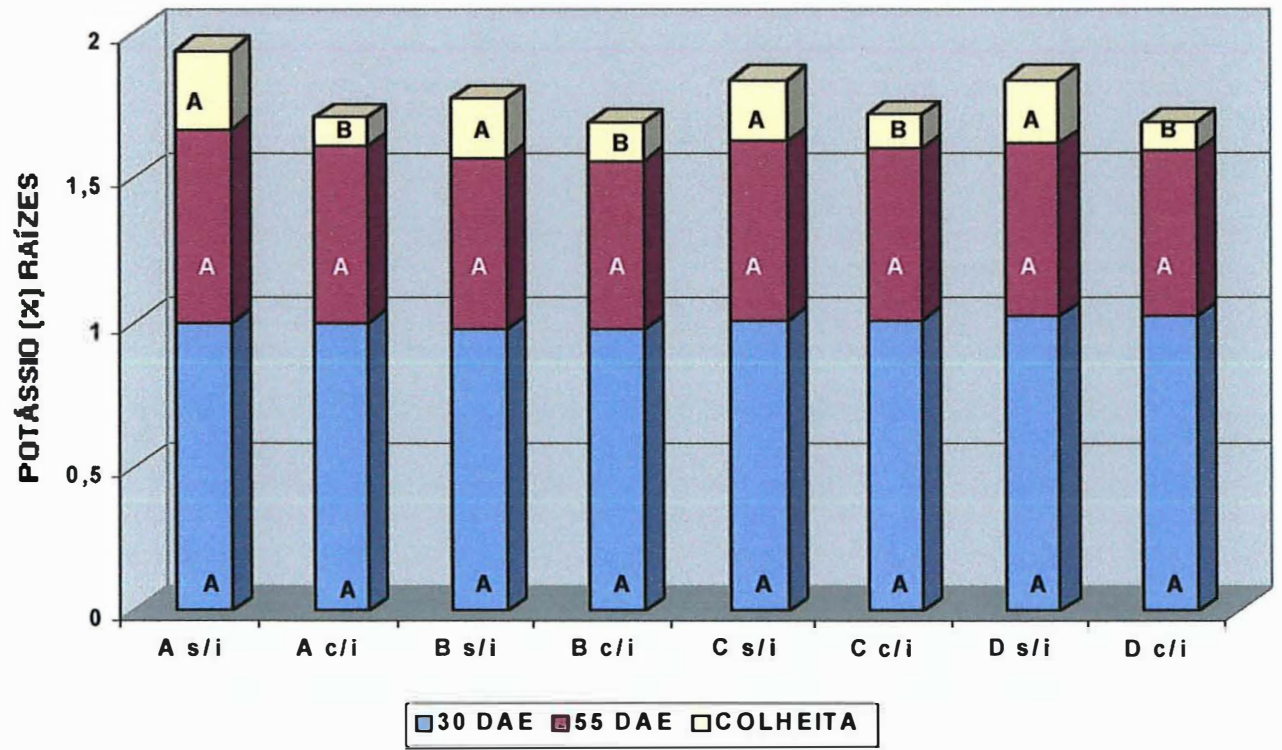

Figura 14. Teor de potássio na parte aérea (A) e raízes (B) de plantas de cultivares ${ }^{1}$ de arroz irrigado, livres (s/i) e infestadas (c/i) por Oryzophagus oryzae, durante o ciclo de desenvolvimento da cultura. Pelotas, RS, 1997/98 e 1998/99. Médias seguidas de letras distintas na mesma cultivar e época de avaliação diferem pelo teste de Tukey $(\mathrm{P} \leq 0,05)$.

' (A) BR IRGA 410; (B) BRS FIRMEZA; (C) Dawn; (D) BRS ATALANTA. 
e somente na parte aérea e nas raízes para 'BRS FIRMEZA' e 'Dawn', respectivamente (Figura 15 A e B).

Correlação positiva foi observada entre o número e peso de larvas e a redução do teor do nutriente na parte aérea, em ambas as épocas de avaliação após o dano do inseto e $55 \mathrm{DAE}$ nas raízes (Tabelas 09 a 12). Portanto, a redução do teor de cálcio tanto da parte aérea como das raízes das plantas foi afetada de forma similar pela quantidade e tamanho de larvas.

\subsubsection{Magnésio}

Antes da infestação do inseto, $30 \mathrm{DAE}$, não houve diferença significativa no teor de magnésio entre plantas da mesma cultivar, tanto na parte aérea como no sistema radicular. Entretanto, após o dano das larvas, $55 \mathrm{DAE}$, a redução do teor do nutriente na parte aérea e raízes da planta foi significativa para as cultivares BR IRGA 410 e BRS ATALANTA, e na colheita, a diferença só não foi significativa para a 'Dawn' na parte aérea (Figura 16 A e B).

Correlação positiva entre número de larvas com a redução do teor do nutriente (Tabelas 9 e 10), somente foi observada 55 DAE, nas raízes da planta. Entretanto, o peso de larvas foi correlacionado postitivamente com a redução do teor do nutriente, também somente $55 \mathrm{DAE}$, porém, tanto na parte aérea como nas raízes da planta (Tabelas 11 e 12). Isto revela que a diferença no teor do nutriente na colheita, nos diferentes órgãos de plantas livres e infestadas, não foi associada à intensidade do ataque de larvas de $O$. oryzae, possivelmente sendo influenciada pelo ciclo de desenvolvimento, já que para o teor da parte aérea, a cultivar Dawn (maior ciclo) não apresentou diferença. 
A

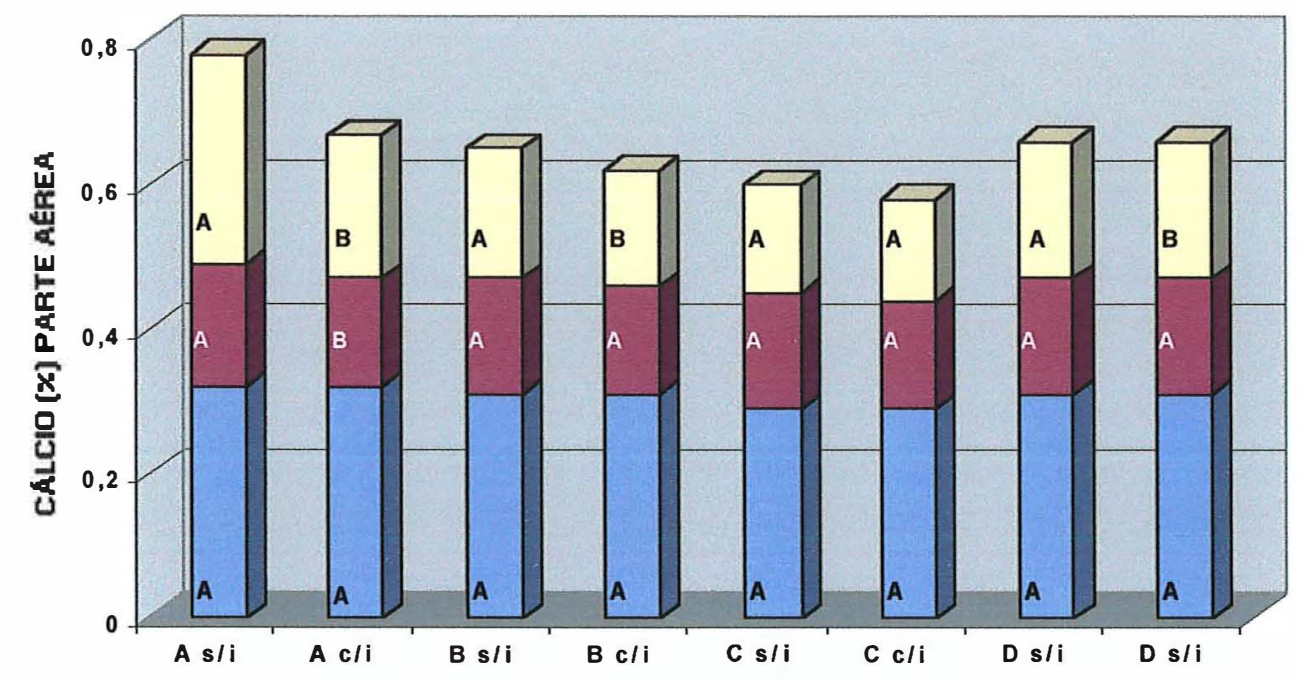

Q30 DAE M55 DAE QCOLHEITA

B

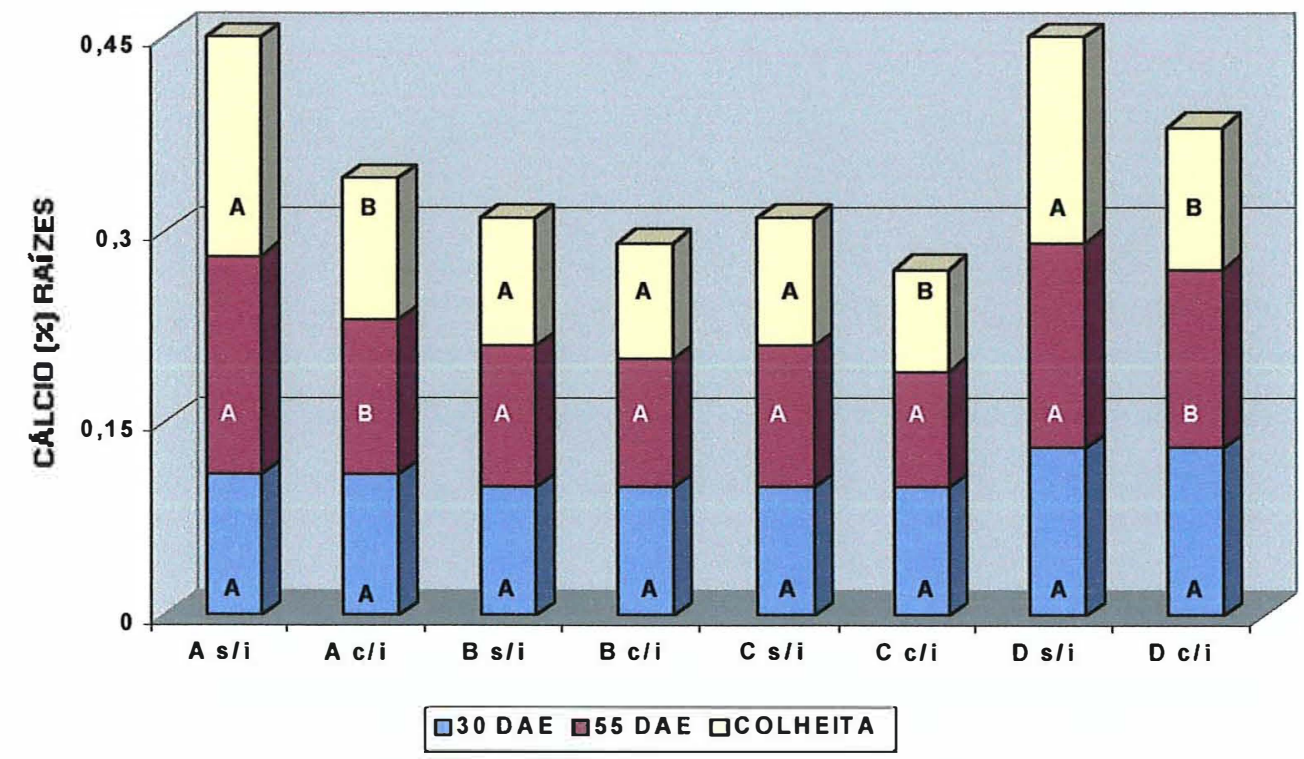

Figura 15. Teor de cálcio na parte aérea (A) e raízes (B) de plantas de cultivares ${ }^{1}$ de arroz irrigado, livres (s/i) e infestadas (c/i) por Oryzophagus oryzae, durante o ciclo de desenvolvimento da cultura. Pelotas, RS, 1997/98 e 1998/99. Médias seguidas de letras distintas na mesma cultivar e época de avaliação diferem pelo teste de Tukey $(\mathrm{P} \leq 0,05)$.

' (A) BR IRGA 410; (B) BRS FIRMEZA; (C) Dawn; (D) BRS ATALANTA. 
A

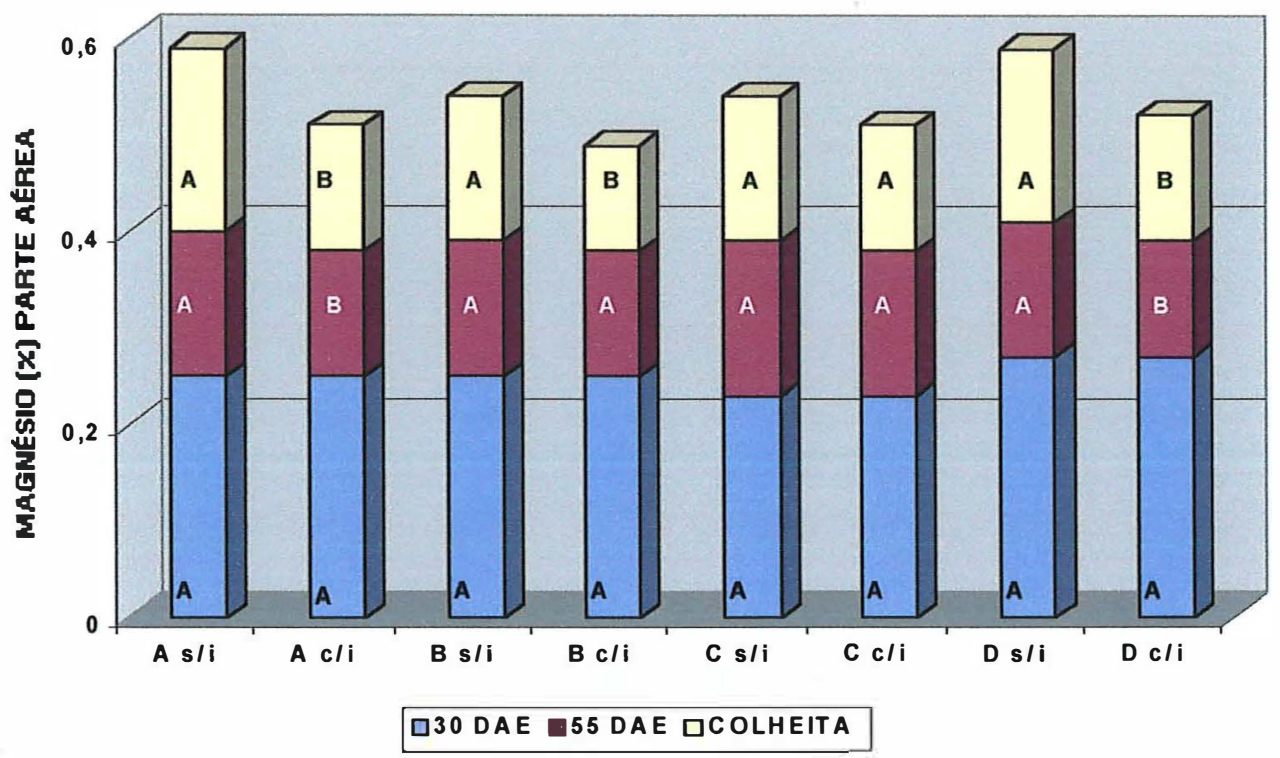

B

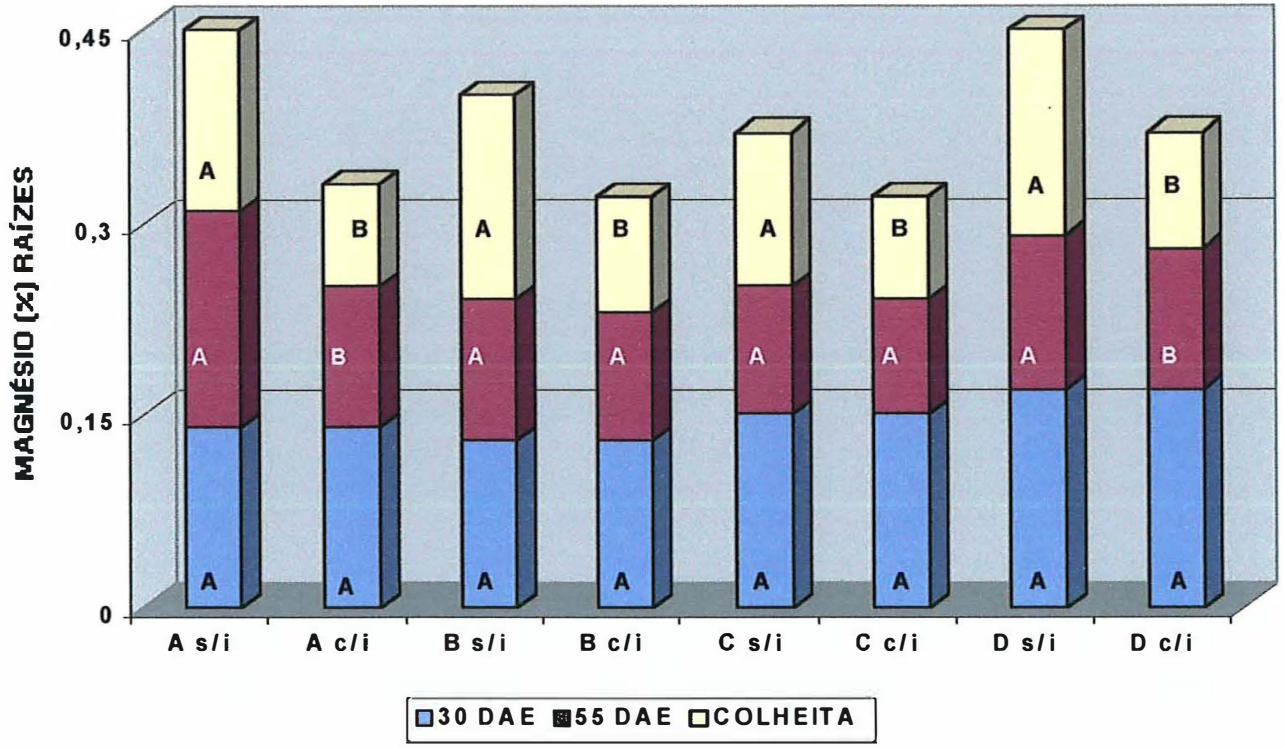

Figura 16. Teor de magnésio na parte aérea (A) e raízes (B) de plantas de cultivares ${ }^{1}$ de arroz irrigado, livres (s/i) e infestadas (c/i) por Oryzophagus oryzae, durante o ciclo de desenvolvimento da cultura. Pelotas, RS, 1997/98 e 1998/99. Médias seguidas de letras distintas na mesma cultivar e época de avaliação diferem pelo teste de Tukey $(\mathrm{P} \leq 0,05)$.

${ }^{1}$ (A) BR IRGA 410; (B) BRS FIRMEZA; (C) Dawn; (D) BRS ATALANTA. 


\subsubsection{Sílica}

O teor de sílica na parte aérea e sistema radicular da planta aumentou com o desenvolvimento da planta. Na primeira avaliação, antes da infestação do inseto, 30 DAE, não houve diferença significativa entre plantas, da mesma cultivar, livres e infestadas pelo inseto. Após o dano das larvas, $55 \mathrm{DAE}$, a redução do teor do nutriente só foi significativa nas raízes e apenas para a cultivar Dawn. Na colheita das plantas, não houve diferença nas quatro cultivares avaliadas (Figura 17 A e B). A diferença no teor de sílica observada 55 DAE e não mais na colheita, na 'Dawn', sugere uma recuperação do sistema radicular, decorrida do maior ciclo de desenvolvimento apresentado por esta cultivar (Carbonari et al., 2000).

Não houve correlação entre o número e peso de larvas do inseto e a redução do teor do nutriente na parte aérea e sistema radicular da planta (Tabelas 9 a 12). Isto revela que o ataque de $O$. oryzae não afetou significativamente a absorção de sílica pelas raízes e consequentemente sua concentração na parte aérea da planta.

\subsubsection{Lignina}

A lignina, não considerada nutriente e sim uma estrutura química complexa de polímeros (Barbosa Filho, 1987 e Malavolta, 1987), não apresentou diferença em seu teor, nas plantas da mesma cultivar, antes do ataque das larvas de $O$. oryzae (30 DAE). Entretanto, após o dano do inseto $55 \mathrm{DAE}$, houve diferença na parte aérea de plantas livres e infestadas pelo inseto, nas cultivares BR IRGA 414 e BRS FIRMEZA e no sistema radicular em todas elas com exceção da 'BR IRGA 414'. Na colheita a diferença do elemento químico entre plantas livres e infestadas manifestou-se na parte aérea das cultivares Dawn e BRS ATALANTA e nas raízes da 'BR IRGA 414' e 'BRS ATALANTA' (Figura 18 A e B). Deve-se destacar que, ao contrário dos nutrientes avaliados, o teor de lignica tende a ser maior nas plantas com infestação em relação às sem infestação. Isto deve-se a uma reação natural da planta de arroz, intensificando a lignificação do sistema radicular após o dano sofrido por larvas de $O$. oryzae (Martins et al., 1995). 
A

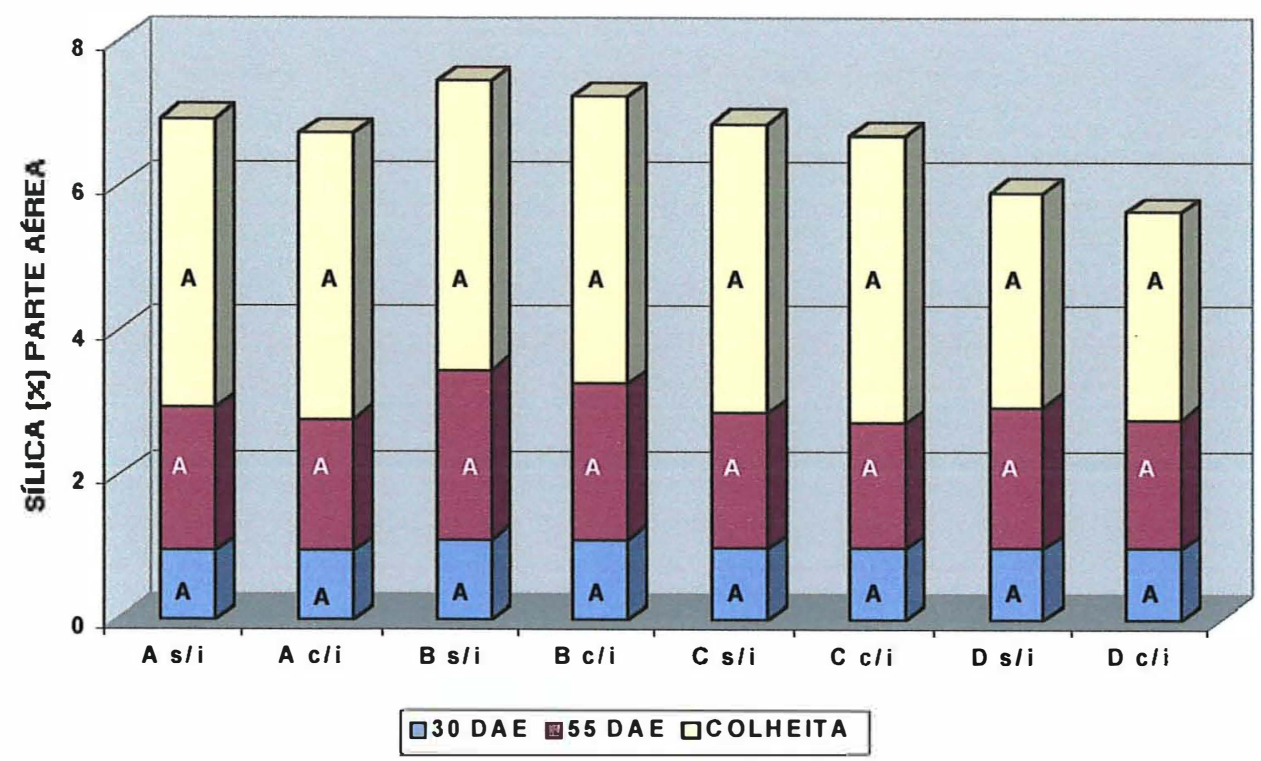

B

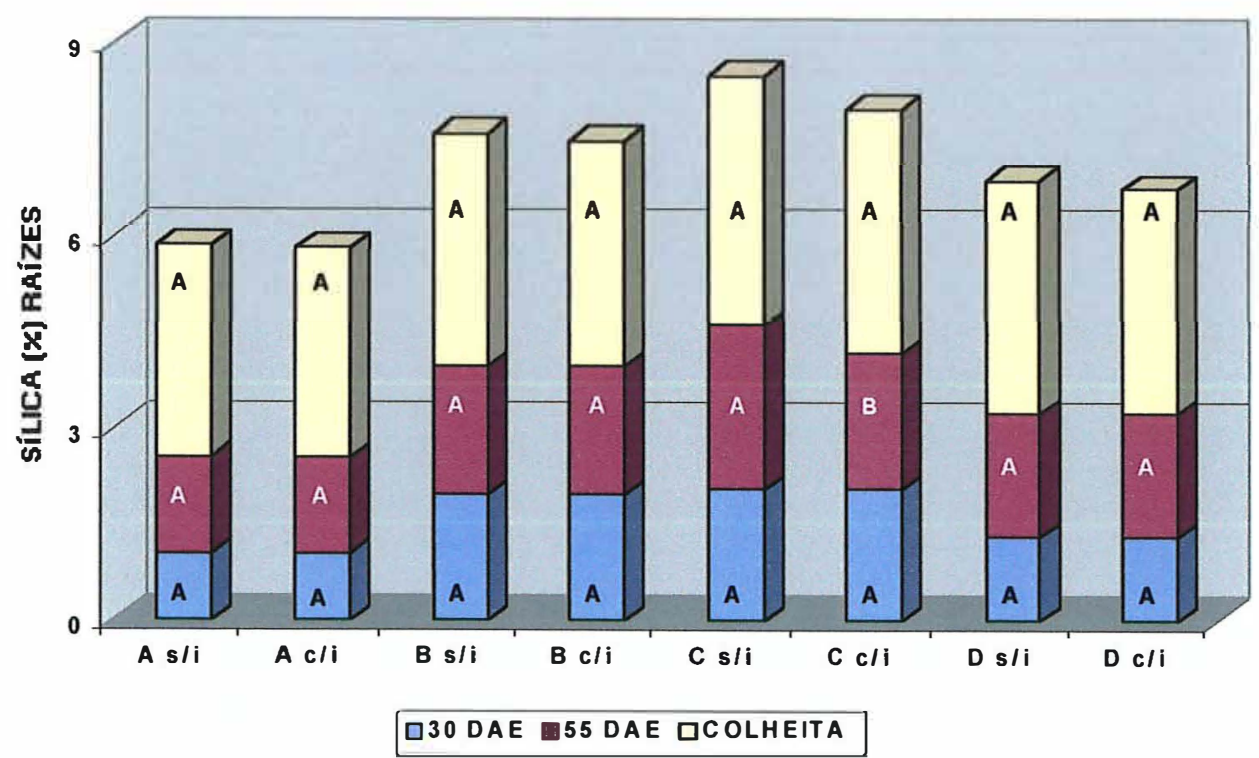

Figura 17. Teor de sílica na parte aérea $(\mathrm{A})$ e raízes $(\mathrm{B})$ de plantas de cultivares ${ }^{1}$ de arroz irrigado, livres (s/i) e infestadas (c/i) por Oryzophagus oryzae, durante o ciclo de desenvolvimento da cultura. Pelotas, RS, 1997/98 e 1998/99. Médias seguidas de letras distintas na mesma cultivar e época de avaliação diferem pelo teste de Tukey $(\mathrm{P} \leq 0,05)$.

' (A) BR IRGA 410; (B) BRS FIRMEZA; (C) Dawn; (D) BRS ATALANTA. 
A

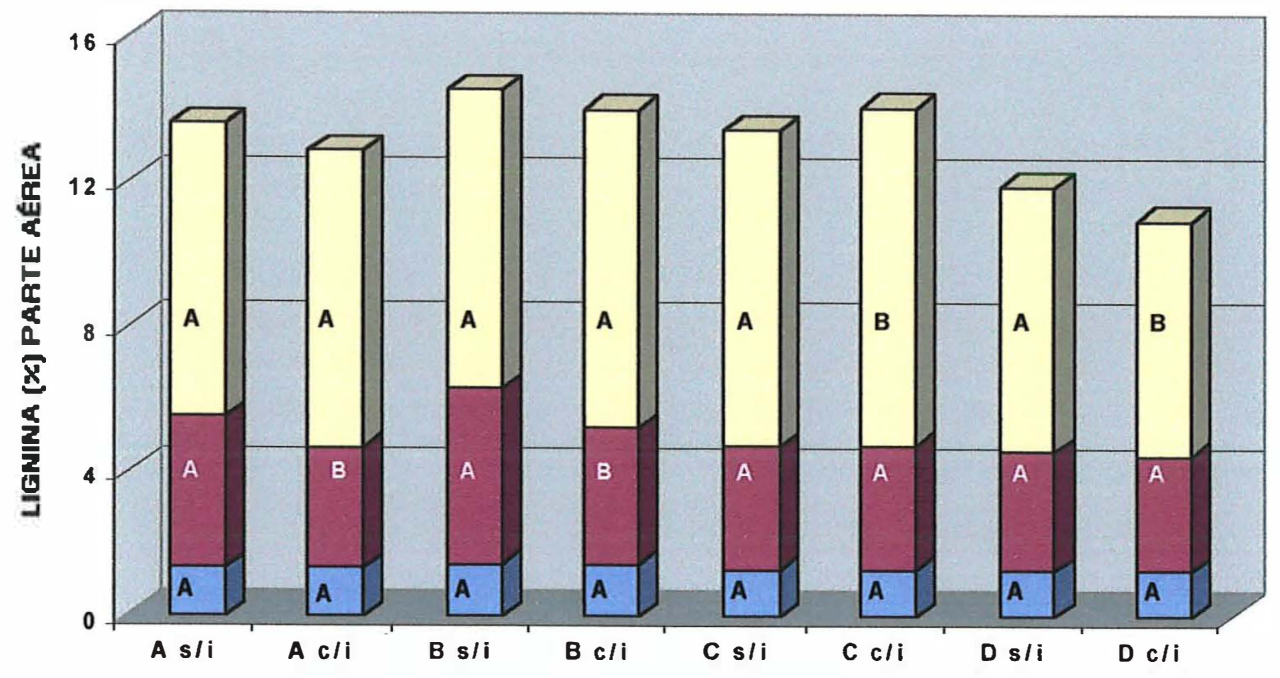

प30 DAE 난 5 DAE DCOLHEITA

B

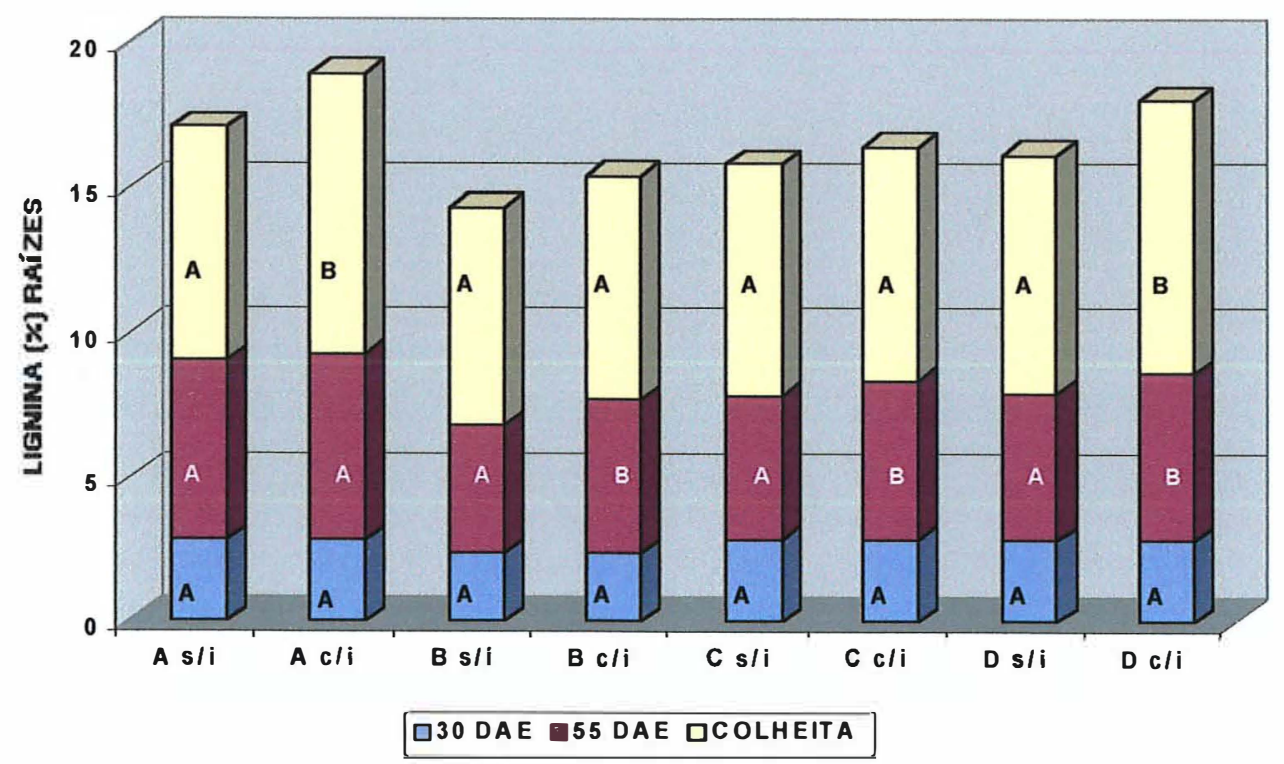

Figura 18. Teor de lignina na parte aérea (A) e raízes (B) de plantas de cultivares ${ }^{1}$ de arroz irrigado, livres (s/i) e infestadas (c/i) por Oryzophagus oryzae, durante o ciclo de desenvolvimento da cultura. Pelotas, RS, 1997/98 e 1998/99. Médias seguidas de letras distintas na mesma cultivar e época de avaliação diferem pelo teste de Tukey $(\mathrm{P} \leq 0,05)$.

' (A) BR IRGA 410; (B) BRS FIRMEZA; (C) Dawn; (D) BRS ATALANTA. 
Correlações lineares entre número de larvas de $O$. oryzae com a diferença (sem e com infestação) do teor de lignina foram observadas na parte aérea somente na colheita das plantas (Tabela 9) e nas raízes, 55 DAE e colheita (Tabela 10). Com o peso de larvas, a correlação ocorreu, na parte aérea, apenas na colheita das plantas (Tabela 11) e nas raízes, apenas aos 55 DAE (Tabela 12). Portanto, fica evidenciada, principalmente para o sistema radicular das plantas, a associação do teor de lignina com a infestação de $O$. oryzae.

\subsubsection{Efeito sobre a produção de grãos}

Houve diferença na produção de grãos obtida entre plantas infestadas e livres do ataque de $O$. oryzae para as cultivares de arroz avaliadas (Figura 19). A cultivar BR IRGA 410 apresentou maior índice de perda, enquanto que as demais não diferiram significativamente entre si. A perda de produção foi correlacionada positivamente com a diferença do teor de nutrientes presente na parte aérea e sistema radicular de plantas infestadas e livres do inseto (exceto com o teor de sílica), número de ovos, peso e número de larvas de $O$. oryzae (Tabela 13).

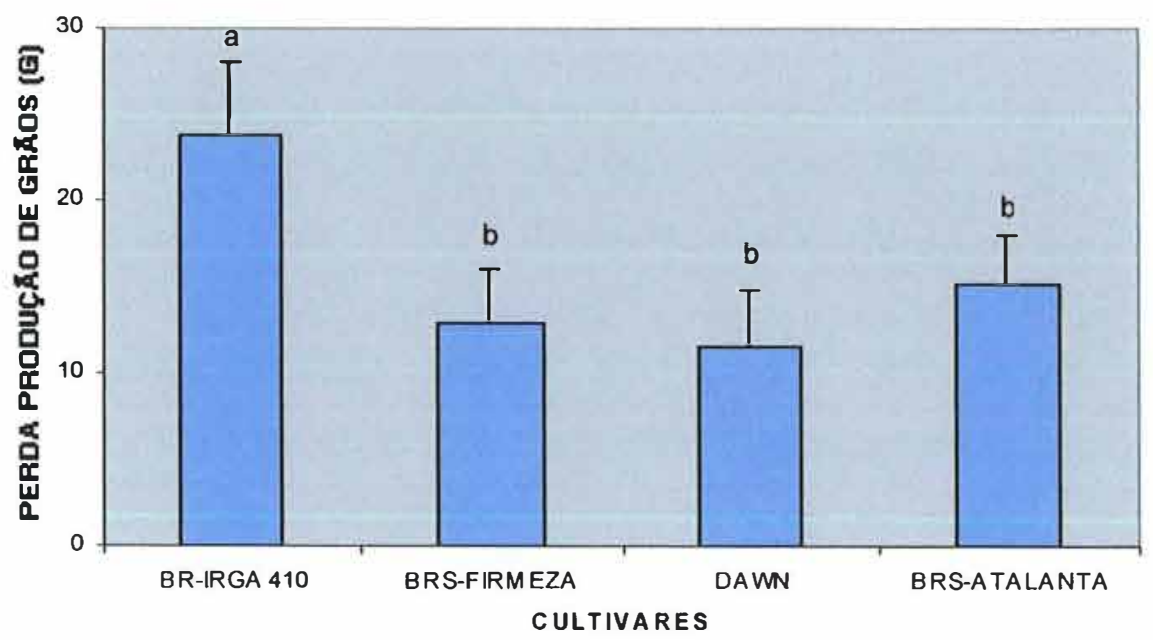

Figura 19. Perda de produção (g/parcela) de grãos, em cultivares de arroz irrigado, submetidas ao ataque de Oryzophagus oryzae. Pelotas, RS, 1997/98 e 198/99. Médias $( \pm \mathrm{EP})$ seguidas de letras distintas diferem pelo teste de Tukey $(\mathrm{P} \leq 0,05)$. 
Tabela 13. Coeficientes de correlação linear entre porcentagem (diferença entre com e sem infestação do inseto) de nutrientes da parte aérea da planta $(r)^{1}$, raízes $(r)^{2}$ (avaliados na colheita das plantas), folhas lesionadas, número de ovos, peso e número de larvas de Oryzophagus oryzae e perda de produção de grãos (g/parcela), em cultivares de arroz irrigado. Pelotas, RS, 1997/98 e 1998/99.

\begin{tabular}{lclccc}
\hline Combinações de Variáveis & & $\mathbf{N}^{1}$ & $\mathbf{( r )}^{1}$ & $\mathbf{( r )}^{\mathbf{2}}$ \\
\hline Nitrogênio & $\mathrm{x}$ & Perda de produção & 4 & $0,903^{*}$ & $0,895^{*}$ \\
Fósforo & $\mathrm{x}$ & Perda de produção & 4 & $0,733^{*}$ & $0,883^{*}$ \\
Cálcio & $\mathrm{x}$ & Perda de produção & 4 & $0,974^{*}$ & $0,743^{*}$ \\
Magnésio & $\mathrm{x}$ & Perda de produção & 4 & $0,924^{*}$ & $0,924^{*}$ \\
Potássio & $\mathrm{x}$ & Perda de produção & 4 & $0,882^{*}$ & $0,959^{*}$ \\
Sílica & $\mathrm{x}$ & Perda de produção & 4 & 0,014 & 0,346 \\
Folhas lesionadas & $\mathrm{x}$ & Perda de produção & 4 & \multicolumn{2}{c}{0,411} \\
Ovos/planta & $\mathrm{x}$ & Perda de produção & 4 & \multicolumn{2}{c}{$0,964^{*}$} \\
Larvas/planta & $\mathrm{x}$ & Perda de produção & 4 & \multicolumn{2}{c}{$0,959^{*}$} \\
Peso de larvas & $\mathrm{x}$ & Perda de produção & 4 & \multicolumn{2}{c}{$0,896^{*}$} \\
\hline
\end{tabular}

${ }^{T}$ Número de combinações entre variáveis.

"Significativo pelo teste " $t$ " a $1 \%(r \geq 0,917), 5 \%(r \geq 0,811)$ e $10 \%(r \geq 0,729)$.

As correlações positivas entre a perda de produção de grãos e as variáveis referentes ao inseto evidenciam o efeito da alimentação deste sobre as plantas. O efeito negativo do número de ovos sobre a produção de grãos evidencia que as plantas mais ovipositadas apresentaram maior número de larvas.

A associação do número e peso de larvas de $O$. oryzae com a redução da absorção de nutrientes pelas e raízes e, consequentemente, o menor teor destes na parte aérea da planta (item 4.2.1), também refletiu na produção de grãos. Somente o teor de sílica não influenciou na redução da produção de grãos de plantas de arroz, sugerindo sua participação indireta na produção, associada a outros nutrientes como ferro, manganês e fósforo (Barbosa Filho, 1987; Deren et al., 1992; Malavolta, 1980, 1987). 


\subsection{Considerações finais}

A alimentação de adultos de $O$. oryzae sobre as cultivares de arroz, caracterizada pelo aparecimento de folhas lesionadas, foi estimulada pelo teor de nitrogênio na parte aérea da planta, nas condições de com e sem chance de escolha do hospedeiro, e pelo potássio somente na condição de sem chance de escolha. Já o teor de sílica na parte aérea da planta, em ambas as condições de experimentação, inibiu a alimentação dos adultos do inseto.

A oviposição de $O$. oryzae foi associada positivamente com os teores de nitrogênio, cálcio e potássio, nas condições de com e sem chance de escolha do hospedeiro, e com o fósforo, somente na condição de sem chance de escolha. Negativamente, o único elemento químico associado com a oviposição do inseto foi a sílica.

Com os nutrientes da parte aérea da planta, a população larval de $O$. oryzae (número de larvas/planta) foi associada positivamente com os teores de nitrogênio e potássio (com e sem chance de escolha do hospedeiro) e cálcio e fósforo (sem chance de escolha), e negativamente (com e sem chance de escolha) com sílica. Já com os elementos químicos das raízes da planta, a população larval associou-se positivamente com os teores de lignina e fósforo (com e sem chance), potássio (com chance) e magnésio (sem chance) e negativa mente com sílica, em ambas as condições de escolha do hospedeiro.

O desenvolvimento larval (peso de larvas) de $O$. oryzae foi favorecido pelo teor de potássio nas raízes, em ambas as condições de experimentação e pelo teor de fósforo somente na condição de sem chance. A sílica foi o único elemento químico das raízes que afetou negativamente o desenvolvimento larval do inseto. A associação positiva com lignina é decorrente do estímulo à lignificação, após o dano do inseto. Os demais elementos químicos quantificados na parte aérea e nas raízes da planta não apresentaram relação com as variáveis avaliadas sobre o inseto.

Anteriormente à infestação de $O$. oryzae, 30 dias após a emergência das plantas (DAE), os teores dos elementos químicos avaliados tanto na parte aérea como 
nas raízes das plantas de cada cultivar de arroz não apresentaram diferença significativa, evidenciando que as parcelas mantidas com e sem infestação estavam homogêneas quanto ao teor destes elementos.

Após a infestação do inseto, $55 \mathrm{DAE}$, para o teor de nitrogênio e fósforo, respectivamente nas raízes e parte aérea e raízes da cultivar BRS FIRMEZA, não houve diferença significativa, entre plantas livres e infestadas pelo inseto. Comportamento semelhante apresentou a cultivar Dawn com o teor de fósforo na parte aérea. Nas demais cultivares e órgãos avaliados, a diferença foi significativa. Para as quatro cultivares, nesta época de avaliação, o teor de potássio, em ambos os órgãos da planta, e de sílica na parte aérea, não apresentaram diferença significativa entre plantas livres e infestadas por $O$. oryzae. O teor de sílica apresentou diferença significativa apenas nas raízes da cultivar Dawn. A redução do teor de cálcio foi significativa, em ambos os órgãos de plantas infestadas da cultivar BR IRGA 410 e nas raízes da 'BRS ATALANTA'. Parte aérea e raízes das cultivares BR IRGA 410 e BRS ATALANTA, apresentaram diferença significativa no teor de magnésio entre plantas livres e infestadas pelo inseto. Já parà o teor de lignina não houve redução, na parte aérea das cultivares Dawn e BRS ATALANTA e nas raízes de 'BR IRGA 410'.

$\mathrm{Na}$ colheita, a determinação dos elementos químicos teve o intuíto de avaliar a recuperação do teor destes elementos nas plantas, após o dano provocado pelo inseto. Desta forma, somente foi observada recuperação na cultivar Dawn para o teor de nitrogênio, fósforo e sílica, nas raízes da planta. Tal comportamento é sugerido pelo fato da cultivar Dawn apresentar concomitantemente menor número de larvas e maior ciclo de desenvolvimento (135 dias), comparada com as demais. Ao contrário dos demais elementos químicos o teor de lignina é maior teor nas plantas infestadas pelo inseto, devido à intensificação da lignificação após o dano às raízes provocado pelas larvas de O. oryzae.

$\mathrm{O}$ ataque de larvas de $O$. oryzae às raízes das quatro cultivares avaliadas provoca redução do teor de nitrogênio, fósforo, potássio, cálcio e magnésio, tanto na parte aérea como nas raízes, e consequentemente perda na produção de grãos. 


\section{CONCLUSÕES}

A alimentação de adultos de Oryzophagus oryzae nas cultivares de arroz BR IRGA 410, BRS FIRMEZA, Dawn e BRS ATALANTA é estimulada pelos teores de nitrogênio e potássio, e inibida pelo teor de sílica, presentes na parte aérea das plantas.

A oviposição de $O$. oryzae nessas cultivares é estimulada pelos teores de nitrogênio, cálcio e potássio, e inibida pelo teor de sílica.

A população larval de $O$. oryzae nas quatro cultivares aumenta com o incremento do teor de fósforo e diminui com o aumento do teor de sílica, presentes nas raízes.

O desenvolvimento larval de $O$. oryzae nas referidas cultivares é estimulado pelo potássio e inibido pela sílica.

O dano às raizes, provocado por larvas de $O$. oryzae, reduz o teor de nitrogênio, fósforo, potássio, cálcio e magnésio, e aumenta o teor de lignina nas plantas das quatro cultivares avaliadas.

Dentre as cultivares testadas, 'Dawn', é a única que consegue recuperar o teor de nitrogênio, fósforo e sílica das raízes da planta, após o dano provocado por larvas de O. oryzae. 
$\mathrm{O}$ ataque de larvas de $O$. oryzae às raízes das quatro cultivares avaliadas provoca redução do teor de nitrogênio, fósforo, potássio, cálcio e magnésio e, consequentemente, perda na produção de grãos. 


\section{REFERÊNCIAS BIBLIOGRÁFICAS}

AUCLAIR, J.L; BALDOS, E. Feeding by the whitebacked planthopper, Sogatella furcifera, within susceptible and resistant rice varieties. Entomologia Experimental \& Applicata, v.32, p.200-203, 1982

AUCLAIR, J.L.; BALDOS, E.; HEIRICHS, E.A. Biochemical evidence for the feeding sites of the leafhopper, Nephotettix virescens within susceptible and resistant rice plants. Insect Science Application, v.3, p.29-34, 1982.

BANG, Y.H.; TUGWELL, P. Adult rice water weevil feeding preferences for rice plants and leaves of different ages. Arkansas: Agricultural Experimental Station, 1976. 12p. (Report Series, 231)

BARBOSA FILHO, M.P. Nutrição e adubação do arroz: (sequeiro e irrigado). Piracicaba: Associação Brasileira para Pesquisa da Potassa e do Fosfato, 1987 129p. (POTAFOS. Boletin Técnico, 9).

BOTTON, M. Resistência varietal e nível de dano de Oryzophagus oryzae (Costa Lima, 1936) (Coleoptera: Curculionidae) em cultivares de arroz irrigado. Piracicaba, 1994. 73p. Dissertação (Mestrado) - Escola Superior de Agricultura "Luiz de Queiroz", Universidade de São Paulo. 
BOTTON, M.; VENDRAMIM, J.D.; MARTINS, J.F.S. et al. Associação entre densidade populacional de Oryzophagus oryzae (Costa Lima) e produção de grãos em cultivares de arroz irrigado. Anais da Sociedade Entomológica do B rasil, v.25, n.2, p.233-238, 1996.

BOWLING, C.C. Effect of nitrogen levels on rice water weevil populations. Journal of Economic Entomology, v.55, p.826-827, 1963.

BOWLING, C.C. Procedure for screening rice varieties for resistance to the rice water weevil. Journal of Economic Entomology, v.66, p.572-573, 1973.

BOWLING, C.C. Breeding for host plant resistance to rice field insects in the U.S.A. In: HARRIS, M.K. (Ed.) Biology and breeding for resistance to arthropods and pathogens in agricultural plants. College Station: Texas A \& M University, 1980. p.329-364.

BREMNER, J.M. Total nitrogen. In: BLACK, C.A. (Ed.) Methods of soil analysis. Madison: AS A, 1965. pt.2, p.1149-1178. (Agronomy Series, 9)

CAMARGO, L.M.O.A. Gorgulhos aquáticos do arroz. caracterização e controle. Lavoura Arrozeira, v.44, n.395, p.7-14, 1991.

CAMARGO, L.M.O.A.; LEITE, N.; VILLELA, O.V. et al. Gorgulhos aquáticos (Coleoptera: Curculionidae) que ocorrem em cultivos de arroz no vale do Paraíba, SP. Arquivos do Instituto Biológico, v.57, n.1/2, p.51-55, 1990. 
CARBONARI, J.J. Simulação de dano e flutuação populacional de Oryzophagus oryzae (Costa Lima, 1936) (Coleoptera: Curculionidae) em cultivares de arroz irrigado. Piracicaba, 1996. 69p. Dissertação (Mestrado) - Escola Superior de Agricultura "Luiz de Queiroz", Universidade de São Paulo.

CARBONARI, J.J.; BOTTON, M.; MARTINS, J.F.S. et al. Efeito do tratamento químico de sementes de arroz na população larval de Oryzophagus oryzae (Costa Lima, 1936). In: CONGRESSO BRASILEIRO DE ENTOMOLOGIA, 16., Salvador, 1997. Resumos. Salvador: Embrapa, CNPMF, 1997. p.177.

CARBONARI, J.J.; MARTINS, J.F.S.; BOTTON, M. et al. Controle de Oryzophagus oryzae (Costa Lima, 1936) com inseticidas aplicados no tratamento de sementes e na água de irrigação na cultura do arroz irrigado. In: CONGRESSO BRASILEIRO DE ENTOMOLOGIA, 15., Caxambu, 1995. Resumos. Lavras: ESAL, 1995. p.420.

CARBONARI, J.J.; MARTINS, J.F.S.; VENDRAMIM, J.D. et al. Relação entre flutuação populacional de Oryzophagus oryzae (Costa Lima) (Coleoptera: Curculionidae) e período de perfilhamento de cultivares de arroz irrigado. Anais da Sociedade Entomológica do Brasil, v.29, n.2, p.361- 366, 2000.

CARBONARI, J.J.; MARTINS, J.F.S.; VERONEZ, A.B.C. et al. Influência do tratamento químico de sementes associado a densidades de semeadura sobre Oryzophagus oryzae (Costa Lima, 1936) na cultura do arroz irrigado. In: CONGRESSO BRASILEIRO DE ENTOMOLOGIA, 17, Rio de Janeiro, 1998. Resumos. Rio de Janeiro: Universidade Federal Rural do Rio de Janeiro, 1998. p.347. 
CHEN, C.; LIU, T.; CHEN, C.L. et al. A studi on the correlation between sten characteristics of rice and its resistance to the striped stem borer. Bulletin of Taichung District Agricultural Improvement Station, n.43, p. 1-6, 1994.

CRUZ, F.Z. Controle da bicheira da raiz do arroz - Oryzophagus oryzae (Lima, 1936) (Col., Curculionidae, Erirhininae) com Cyclosal (cicloprotrin) um novo inseticida piretróide. Lavou ra Arrozeira, v.45, n.404, p.11-12, 1992.

CUNHA, U.S. da; CARBONARI, J.J.; MARTINS, J.F.S. et al. Melhoramento genético de arroz irrigado na Embrapa Clima Temperado. 9. Avaliação da resistência ao gorgulho aquático Oryzophagus oryzae (Coleoptera: Curculionidae), em arroz irrigado. In: CONGRESSO BRASILEIRO DE ARROZ IRRIGADO 1.; REUNIÃO DA CULTURA DO ARROZ IRRIGADO, 22., Pelotas, 1999. Anais. Pelotas: Embrapa Clima Temperado, 1999. p.465-468.

DATNOFF, L.E.; SNYDER, G.H.; DEREN, C.W. Influence of silicon fertilizer grades on blast and brown spot development and on rice yields. Plant Disease, v.76, p.1182-1184, 1992.

DATNOFF, L.E.; RAID, D.R.; SNYDER, G.H. et al. Effect of calcium silicate on blast and brown spot intensities and yields of rice. Plant Disease, v. 75, p.729-732, 1991.

DEREN, C.W.; DATNOFF, L.E.; SNYDER, G.H. Variable silicon content of rice cultivars grown on everglades histosols. Journal of Plant Nutrition, v.15, p.2363-2368, 1992. 
DEREN, C.W.; DATNOFF, L.E.; SNYDER, G.H. et al. Silicon concentration, disease response and yield components of rice genotypes grown on flooded organic histosols. Crop Science, v.34, p.733-737, 1994.

DJAMIN, A.; PATHAK, M.D. Role of silica in resistance to asiatic rice borer, Chilo suppressalis (Walker), in rice varieties. Journal of Economic Entomology, v.60, n.2, p.347-351, 1967.

DRAVÉ, H.; LAUGE, G. Étude de l'action de la silice sur l'usure des mandibules de la pyrale du riz: Chilo suppressalis (F.) (Walker) (Lep. Pyralidae Crambinae). Bulletin de la Société entomologique de France, v.83, n.7/8, p.159-162, 1978.

EPSTEIN, E. The anomaly of silicom in plant biology. Proceedings of the National Academy of Sciences of the USA, v. 91, n. 1, p. 1118-1119, 1994.

FERREIRA, E.; MARTINS, J.F.S. Insetos prejudiciais ao arroz no Brasil e seu controle. Goiânia: EMBRAPA, CNPAF, 1984. 67p. (EMBRAPA. CNPAF. Documentos, 11).

GHOSH, B.N. A note on the incidence of stem borer (Schoenobius incertulas Walker) on boro paddy under nitrogen fertilizars. Current Science, v.31, n.11, p.472-473, 1962.

GIFFORD, J.R.; TRAHAN, G.B. Staining technique for eggs of rice water weevil. Oviposited intracellulary in the tissue of the leaf sheaths of rice. Journal of Economic Entomology, v.62, p.740-741, 1969. 
GRAYER, R.J.; HARBORNE, J.B.; KIMMINS, F.M. et al. Phenolics in rice phloen sap as suching deterrents to the brown planthopper, Nilaparvata lugens. Acta Horticulturae, n.381, p.691-694, 1994.

GRIGARICK, A.A.; BEARDS, G.W. Ovipositional habits of the rice water weevil in California as related to a greenhouse evaluation of seed treatments. Journal of Economic Entomology, v.58, p.1053-1056, 1965.

HEINRICHS, E.A.; MEDRANO, F.G.; RAPUSAS, H.R. Genetic evaluation for insect resistance in rice. Los Baños: IRRI, 1985. 356p.

HIM HIM, P.V. Teste de resistência a "bicheira-da-raiz" (Oryzophagus oryzae, Costa Lima, 1936) em genótipos de arroz (Oryza sativa L.), para fins de melhoramento. Pelotas, 1980. 67p. Dissertação (Mestrado) - Faculdade de Agronomia Eliseu Maciel, Universidade Federal de Pelotas.

HIRANO, C. Studies on the nutritional relationships between larvae of Chilo suppressalis (Walker) and the rice plant, with special reference to role of nitrogen in nutrition of larvae. Bulletin of the National Institute of Agriculture Sciences, n.17, 180p. 1964.

HIRANO, C.; ISHII, S. Effect of fertilizers on the growth of larvae of the rice stem borer Chillo suppressalis (Walker). IV. Growth response of larvae to the rice plant supplied with potassium fertilizer at different levels. Japanese Journal of Applied Entomology and Zoology, v.5, n.3, p.180-184, 1961.

INSTITUTO RIOGRANDENSE DO ARROZ. Recomendações técnicas da pesquisa para o Sul do Brasil. Cachoeirinha: 1995. 83p. 
INTERNATIONAL RICE RESEARCH INSTITUTE. Annual report. Los Baños, 1964. p.157-184: Entomology.

ISHII, S. Nutritional studies of the rice stem borer Chilo suppressalis (Walker), and its mass rearing. Entomophaga, v.16, n.2, p.165-173, 1971.

ISHII, S.; ISHII, S. The major insects pests of the rice plant. Baltimore: John Hopkins Press., 1967. p.229-239: Nutritional studies of the rice stem borer Chilo suppressalis (Walker).

ISHII, S.; HIRANO, C.; IWATA, Y. et al. Isolation of benzoic and salicylic acids from the rice plants as grown-inhibiting factor for the rice stem borer, Chilo suppressalis (Walker) and some rice plant fungus pathogens. Japanese Journal of Applied Entomology and Zoology; v.6, n.4, p.281$288,1962$.

KHAN, Z.R.; SAXENA, R.C. Effect of Steam distillate extracts of resistant and susceptible rice cultivars on behavior of Sogatella furcifera (homoptera: Delphacidae). Journal of Economic Entomology, v.79, p. 928-935, 1986.

KHANAM, L.A.M.; MALEK, M.A.; PARVEEN, B. et al. Extent of damage by Sitrotroga cerealella Oliv. (Lepidoptera: Gelechiidae) to different cultivars of unhusked stored rice Bangladesh. Annals of Entomology, v.8, n.2, p. 2326, 1990.

KIN, M.S.; HEIRICHS, E.A. Effect of silica level on whitebached planthopper. International Rice Research, v.7, n.4, p.17, 1982.

KUSCHEL, G. Revision de Lissorhoptrus Leconte y generos vecinos de America. Revista Chilena de Entomologia, v.1, p.23-74, 1951. 
KUSCHEL, G. Revision de los premmo trypini y adiciones a los bagoini (Coleoptera: Curculionidae). Boletin del Museo Nacional de História, v.26, p.187-235, 1956.

LARA, F.M. Princípios de resistência de plantas a insetos. 2.ed. São Paulo: Ed. Ícone, 1991. 336p.

LI, G.Q.; WANK, Y.; HAN, Z. et al. Resistant factors in the blade of NJ 14 and their influence on food utilization and survival of brown planthopper. Journal of Najing Agricultural University, v.19, n.1, p.42-47, 1996.

LIAN, S. Silica fertilization of rice. In: FOOD AND FERTILIZER TECHNOLOGY CENTER. The fertility of padd soils and fertilizer applications for rice. Taiwan, 1976. p.197-220.

LIMA, A.D.F. O bicho do arroz. Boletim Fitossanitário, v.5, p.49-53, 1951.

LINK, D.; COSTA, E.C. Locais de "hibernação" de adultos de Oryzophagus oryzae (Costa Lima, 1936) na região central do Rio Grande do Sul. In: REUNIÃO SUL-BRASILEIRA DE INSETOS DE SOLO, 3., Chapecó, 1991. Ata. Chapecó: EMPASC, CPPP, 1991. p.18.

LINK, D.; ROSSETTO, C.J. Relação entre fissura na casca do arroz e infestação de Sitotroga cerealella (Olivier, 1819) (Lepidoptera Gelechiidae). In: CONGRESSO LATINO AMERICANO DE ENTOMOLOGIA, v.15, p.225$227,1972$.

MAHATHEER , A.S.; CHIAMPIRIYAKUL, A.; PROMDANG, S. et al. Study on secundary plant compounds of insect resistant and susceptible rice varieties. Jou rnal Natural Sciences, v.29, n.1, p.45-54, 1995. 
MALAVOLTA, E. Elementos de nutrição mineral de plantas. São Paulo: Agronômica Ceres, 1980. $25 \mathrm{lp}$.

Malavolta, E.; VITTI, G. C.; Oliveira, S.A. de. Avaliação do estado nutricional das plantas: princípios e aplicações. 2.ed. Piracicaba: POTAFOS, 1987. 319p.

MARTINS, J.F.S. Níveis de infestação de Oryzophagus oryzae (Costa Lima, 1936) (Coleoptera: Curculionidae) durante o período de desenvolvimento da cultura do arroz. Ciência e Cultura, v.28, n.12, p.1493-1497, 1976.

MARTINS, J.F.S. Profundidade da água de irrigação e nível de infestação da bicheira-da-raiz em arroz. Pesquisa Agropecuária Brasileira, v.14, n.2, p.97-99, 1979.

MARTINS, J.F.S. Problemática da bicheira-da-raiz no Rio Grande do Sul. In: REUNIÃO NACIONAL DE PESQUISA DE ARROZ, 4., Goiânia, 1990. Resumos. Goiânia: EMBRAPA, CNPAF, 1990. p.29.

MARTINS, J.F. S.; BOTTON, M. Controle de insetos da cultura do arroz. P. 273-299. In: PESKE, S.T.; NEDEL, J.L.; ALBUQUERQUE, A.C.S. et al. (Ed.) Produção de arroz irrigado. Pelotas: UFPel, Editora e Gráfica Universitária, 1986. 629p.

MARTINS, J.F.S.; FERREIRA, E. Caracterização e controle da bicheira-daraiz do arroz. Goiânia: EMBRAPA, CNPAF. 1980. 14p. (EMBRAPA. CNPAF. Circular Técnica, 9). 
MARTINS, J.F.S.; TERRES, A.L.S. Avaliação de germoplasma de arroz visando resistência à bicheira-da-raiz. In: REUNIÃO DA CULTURA DO ARROZ IRRIGADO, 18., Porto Alegre, 1989. Anais. Porto Alegre: IRGA, 1989. p.315-320.

MARTINS, J.F.S.; TERRES, A.L.S. Avaliação de germoplasma de arroz visando resistência à bicheira-da-raiz. In: REUNIÃO DA CULTURA DO ARROZ IRRIGADO, 19., Camboriú, 1991. Anais. Itajaí: EPAGRI, 1991. p.229-231.

MARTINS, J.F.S.; TERRES, A.L.S. Avaliação de germoplasma de arroz visando resistência a Oryzophagus oryzae (Costa Lima). Anais da Sociedade Entomológica do Brasil, v.24, n.3, p.445-453, 1995.

MARTINS, J.F.S.; BERTELS, A.; DITTRICH, R.C. Métodos de aplicação de inseticidas no controle da bicheira-do-arroz, Oryzophagus oryzae (Coleoptera: Curculionidae). Pesquisa Agropecuária Brasileira, v.12, p.41-48, 1977a.

MARTINS, J.F.S.; BOTTON, M.; CARBONARI, J.J. Controle de Oryzophagus oryzae (Costa Lima) através da pulverização foliar com inseticidas piretróides. Anais da Sociedade Entomológica do Brasil, v.25, n.2, p.217-221, 1996a.

MARTINS, J.F.S.; BOTTON, M.; CARBONARI, J.J. Efeito de inseticidas no tratamento de sementes e na água de irrigação no controle de Oryzophagus oryzae (Costa Lima) em arroz irrigado. Revista Brasileira de Agrociên cia, v.2, n.1, p.27-32, 1996 b. 
MARTINS, J.F.S.; CARBONARI, J.J.; BOTTON, M. Efeito da época de pulverização foliar de arroz com inseticidas piretróides no controle da bicheira da raiz (Oryzophagus oryzae) (Costa Lima, 1936). Lavoura Arrozeira, v.50, n.431, p.11-14, $1997 \mathrm{~b}$.

MARTINS, J.F.S.; OLIVEIRA, J.V. de; VALENTE, L.A. Informações preliminares sobre a situação de insetos na cultura do arroz irrigado no Rio Grande do Sul. In: REUNIÃO DA CULTURA DO ARROZ IRRIGADO, 17. Pelotas, 1988. Anais. Pelotas: EMBRAPA, CPATB, 1988. p.215-223.

MARTINS, J.F.S.; PARRA, J.R.P.; MIHSFELDT, L.H. Resistência de arroz à broca-do-colmo. I. Avaliação pela alimentação de lagartas em pedaços de colmo. Pesquisa Agropecuária Brasileira, v.24, n.3, p.347-356, 1989.

MARTINS, J.F.S.; PINHEIRO, B.S.; LOWE, J.A. Nitrogênio e infestação da broca do colmo em arroz irrigado. Pesquisa Agropecuária Brasileira, v.13, n.3, p.23-25, 1978.

MARTINS, J.F.S.; TAN, N.V.; PINHEIRO, B.S. Resistência de arroz de sequeiro à broca do colmo e sua associação com características morfológicas das plantas. Pesquisa Agropecuária Brasileira, v.16, n.2, p.187-192, 1981.

MARTINS, J.F.S.; ROSSETTO, C.J.; ROCCIA, A.O. Preferência para oviposição de Diatreae saccharalis (Fabricius, 1974) em variedades de arroz. Anais da Sociedade Entomológica do Brasil, v.6, n.1, p. 64-72, $1977 b$. 
MARTINS, J.F.S.; ROSSETTO, C.J.; ROCCIA, A.O. Resistência de variedades de arroz a lagartas de Diatreae saccharalis (Fabricius, 1974). Ciência e Cultura, v.29, n.10, p. 1141-1145, 1977c.

MARTINS, J.F.S.; TERRES, A.L.S.; BOTTON, M. Alternativas de controle da bicheira-da-raiz visando menor impacto ambiental. Lavoura Arrozeira, v.46, n.406, p.12-14, 1993.

MARTINS, J.F.S.; BOTTON, M.; CARBONARI, J.J. et al. Estratégia de controle de Oryzophagus oryzae (Costa Lima) no sistema de cultivo de arroz pré-germinado. In: REUNIÃO DA CULTURA DO ARROZ IRRIGADO, 21., Porto Alegre, 1995. Anais. Porto Alegre: IRGA, 1995. p.220-222.

MARTINS, J.F.S.; CARBONARI, J.J.; VERONEZ, A.B.C. et al. Seleção de cultivares e linhagens de arroz visando resistência a Oryzophagus oryzae (Costa Lima, 1936). In: CONGRESSO BRASILEIRO DE ENTOMOLOGIA, 17., Rio de Janeiro, 1998. Resumos. Rio de Janeiro: Universidade Federal Rural do Rio de Janeiro, 1998. p.345.

MARTINS, J.F.S.; MELO, M.; CARBONARI, J.J. et al. Eficiência de inseticida de ação fisiológica no controle de Oryzophagus oryzae (Coleoptera: Curculionidae), em arroz irrigado. In: CONGRESSO BRASILEIRO DE ARROZ IRRIGADO 1.; REUNIÃO DA CULTURA DO ARROZ IRRIGADO, 22., Pelotas, 1999. Anais. Pelotas: Embrapa Clima Temperado, 1999. p.458-460.

MARTINS, J.F.S.; RANGEL, P.H.N.; AQUINO, R.L.A. et al. Adubação nitrogenada e controle da bicheira da raiz do arroz. Lavoura Arrozeira, v.40, p.8-11, 1986. 
MARTINS, J.F.S.; TERRES, A.L.S.; CARBONARI, J.J. et al. Avaliação de genótipos de arroz visando resistência do tipo tolerância a Oryzophagus oryzae (Costa Lima, 1936). In: CONGRESSO BRASILEIRO DE ENTOMOLOGIA, 16., Salvador, 1997. Resumos. Salvador: Embrapa, CNPMF, 1997b. p.330.

MARTINS, J.F.S.; TERRES, A.L.S.; CARBONARI, J.J. et al. Melhoramento de arroz irrigado na Embrapa-CPACT: 7 - Tolerância de genótipos de arroz ao gorgulho-aguático Oryzophagus oryzae (Costa Lima, 1936). In: REUNIÃO DA CULTURA DO ARROZ IRRIGADO, 22., Balneário Camboriú, 1997. Anais. Itajaí: EPAGRI, 1997c. p.90-92.

MATSUI, M.; ITO, K.; OKADA, M. et al. Morphological changes in the flight muscles ans the ovary of the rice water weevil adult, Lissorhoptrus oryzophilus Kuschel (Coleoptera: Curculionidae), collected at various sites during the period of migration. Japanese Journal Appliad Entomology and Zoology, v.27, p.183-188, 1983.

MATSUO, T.; FUTSUHARA, Y.; KIKUCHI, F. et al. Science of th ree rice plant. Tokyo: Food and Agriculture Policy Research Center, 1997. v.3, $1003 p$.

MAXUWELL, F.G.; JENNINGS, P.R. Breeding plant resistant to insects. New York: John Wiley, 1980. 683p.

MAXUWELL, F.G.; JENKINS, J.N.; PARROTT, W.L. Resistance of plants of insects. Advances in Agronomy, v. 24, p. 187-265, 1972. 
MENESES, R.; ELIZALDE, R. Influencia de la fertilization mineral en el cultivo del arroz sobre la poblacion de Lissorhoptrus brevirostris (Coleoptera: Curculionidade). Ciência Técnica Agrícola, v.3, p.49-69, 1980.

MIELITZ, L.R.; BECKER, M.; ROMANOWSKI, H.P. Hibernation dynamics of Oryzophagus oryzae and its implications for management. Entomologia Experimentalis et Applicata, v.78, p.159-166, 1996.

MISHRA, B.K.; SONTAKKE, B.K.; MOHAPATRA, H. Antiobiosis mechanisms of resistance in rice varieties to yellow stem borer Scirpophaga incertulas Walker. Indian Journal of Plant Protection, v. 18, n. 1, p. 81 83, 1990 .

MISHRA, N.C.; MISRA, B.C. Role on silica in resistance of rice, Oryza sativa L. to white-backed planthopper, Sogatella furcifera (Horvath) (Homoptera: Delphacidae). Indian Journal of Entomology, v.54, n.2, p. 190-195, 1992.

MOREIRA, G.R.P. Efeito da profundidade da lâmina d'água, densidade e idade da planta de arroz irrigado na seleção do local de oviposição por Oryzophagus oryzae (Coleoptera). CONGRESSO BRASILEIRO DE ZOOLOGIA, 21., Porto Alegre, 1996. Resumos. Porto Alegre: UFRGS, 1996. p.128.

MOREIRA, G.R.P.; SANTOS, M.; GARCIA, S.M.L. et al. Caracterização morfológica da interação respiratória entre as fases aquáticas de Oryzophagus oryzae (Coleoptera) e a planta de arroz irrigado. In: CONGRESSO BRASILEIRO DE ZOOLOGIA, 21., Porto Alegre, 1996. Resumos. Porto Alegre: UFRGS, 1996. p.129. 
MORGAN, D.R.; SLAYMAKER, P.H.; ROBINSON, J.F. et al. Rice water weevil (Coleoptera: Curculionidae) indirect flight muscle development and spring emergence in response to temperature. Envirommental Entomology, v.13, n.1, p.26-28, 1984.

MUDA, A.R.B.; TUGWELL, N.P.; HAIZUP, M.B. History and indirect fligt muscle degeneration and regeneration in the rice water weevil. Environmental Entomology, v.10, n.5, p.685-690, 1981.

MUEGGE, M.A.; RING,D.R.; RICE, W.C. et al. Preliminary analysis of adult rice water weevil flight behavoir for southwest Louisiana. In: RICE RESEARCH STATION. Annual research report. Crowley, 1996. p.578587.

MUNAKATA, K.; SAITO, T.; OGAWA, S. et al. Oryzanone, an attractant of the rice stem borer. Bulletin the Agricultural Chemical Society of Japan, v.23, n.1, p.64-65, 1959.

NAGATA, T. Japan's unwelcome new arrival. Shell Agriculture, v.8, p.8-10, 1990.

NAKANO, K.; ABE, G.; TAKETA, N. et al. Silicon as an insect resistance component of host plant, found in the relation between the rice stem borer and rice plant. Japanese Journal of Applied Entomology and Zoology, v.5, n.1, p.17-27, 1961.

NARAYANASAMY, P.; BASKARAN, P.; BALASUBRAMANIAM, M. et al. Different levels of $\mathrm{N}, \mathrm{P}$ and $\mathrm{K}$ on the incidence of rice insect pests. Rice Entomology Newsletter, v.4, n.1, p.37, 1976. 
NILAKE, S.S. Reproductive status of overwintering rice water weevils. Annals of the Entomological Society of America, v.70, n.4, p.559-601, 1977.

N'GUESSAN, F.K.N.; QUISENBERRY, S.S. Screening selected rice lines for resistance to the rice water weevil (Coleoptera: Curculionidae). Environmental Entomology, v.23, n.3, p.665-675, 1994.

N'GUESSAN, F.K.N.; QUISENBERRY, S.S.; GROUGHAN, T.P. Evaluation of rice anther culture lines for tolerance to the rice water weevil (Coleoptera: Curculionidae). Environmental Entomology, v.23, n.2, p.331-336, 1994 a.

N'GUESSAN, F.K.N.; QUISENBERRY, S.S.; GROUGHAN, T.P. Evaluation of rice tissue culture lines for resistance to the rice water weevil (Coleoptera: Curculionidae). Journal of Economic Entomology, v.87, n.2, p.504-513, 1994b.

NUNES, R.C.F.; SILVA, P.H.S. Resistência de cultivares de arroz recomendadas para o cultivo irrigado e sequeiro no Piauí ao gorgulho Sitophilus sp. In: CONGRESSO BRASILEIRO DE ENTOMOLOGIA, 12., Belo Horizonte, 1989. Resumos. Belo Horizonte: SEB, 1989. p.394.

OLIVEIRA, J.V. de. Estudo de níveis de uréia em bicheira da raiz no arroz irrigado. In: REUNIÃO DA CULTURA DO ARROZ IRRIGADO, 10., Porto Alegre, 1980. Anais. Porto Alegre: IRGA, 1980. p.211-212.

OLIVEIRA, J.V. de. Doses de uréia em bicheira da raiz (Oryzophagus oryzae) (Costa Lima, 1936), em arroz irrigado. In: REUNIÃO DA CULTURA DO ARROZ IRRIGADO, 11., Pelotas, 1981. Anais. Pelotas: EMBRAPA, UEPAE, 1981. p.317-319. 
OLIVEIRA, J.V. de. Caracterização e controle dos principais insetos do arroz irrigado. Lavoura Arrozeira, v.40, n.374, p.17-24, 1987.

OLIVEIRA, J.V. de. Ocorrência da bicheira-da-raiz no Rio Grande do Sul. Lavoura Arrozeira, v.46, n.408, p.16-17, 1993.

OLIVEIRA, J.V. Hibernação da bicheira da raiz Oryzophagus oryzae (Costa Lima, 1936) na cultura do arroz irrigado. In: CONGRESSO BRASILEIRO DE ENTOMOLOGIA, 17., Rio de Janeiro, 1998. Resumos. Rio de Janeiro: Universidade Federal Rural do Rio de Janeiro, 1998. p.189.

OLIVEIRA, J.V. de. Controle químico da bicheira-da-raiz (Oryzophagus oryzae Costa Lima, 1936) em arroz irrigado. Lavoura Arrozeira, v.47, n.413, p.34, 1994.

OLIVEIRA, J. V. Controle da bicheira-da-raíz, Oryzophagus oryzae (Costa Lima, 1936) em tratamento de sementes em arroz irrigado. In: CONGRESSO BRASILEIRO DE ARROZ IRRIGADO 1.; REUNIÃO DA CUlTURA DO ARROZ IRRIGADO, 22., Pelotas, 1999. Anais. Pelotas: Embrapa Clima Temperado, 1999a. p.415-418

OLIVEIRA, J. V. Controle químico da bicheira-da-raíz, Oryzophagus oryzae (Costa Lima, 1936) em arroz irrigado no sistema convencional. In: CONGRESSO BRASILEIRO DE ARROZ IRRIGADO 1.; REUNIÃO DA CUlTURA DO ARROZ IRRIGAdO, 22., Pelotas, 1999. Anais. Pelotas: Embrapa Clima Temperado, 1999b. p.411-414

PANIZZI, A.R.; PARRA, J.R.P. Ecologia nutricional de insetos e suas implicações no manejo de pragas. São Paulo: Ed. Manole, 1991. 359p. 
PATANAKAMJORN, S.; PATHAK, M.D. Varietal resistance of rice to the asiatic rice borer, Chilo suppressalis (Walker), and its association with various plant caracters. Annals of the entomological Society of America, v.60, n.2, p.287-292, 1967.

PATHAK, M.D.; ANDRES, F.; GALACGAC, N. et al. Resistance of rice varieties to striped rice borers. International Rice Research Institute, v.11, p.69, 1971.

PRANDO, H.F. Aspectos bioetológicos e de controle de Oryzophagus oryzae (Costa Lima, 1936) (Coleoptera: Curculionidae) em arroz irrigado, sistema de cultivo pré-germinado. Curitiba, 1999. 102p. Tese (Doutorado) Universidade Federal do Paraná.

PRANDO, H.F.; PEGORARO, R.A. Controle da bicheira-da-raiz do arroz (Oryzophagus oryzae) (Costa Lima, 1936) (Coleoptera: Curculionidae) com tratamento de sementes. In: REUNIÃO DA CULTURA DO ARROZ IRRIGADO, 20., Pelotas, 1993. Anais. Pelotas: EMBRAPA, CPACT, 1993. p.220-221.

PUGLIESE, A. A larva da raiz do arroz. Lavoura Arrozeira, v.9, n.97, p.17$18,1956$.

RAMACHANDRAN, R.; KHAN, Z.R. Mechanisms of resistance rice Oryza brachyantra to rice leaffolder Cnaphalocrocis medinalis (Guenee) (Lepidoptera: Pyralidae). Journal of Chemical Ecology, v. 17, n. 1, p. 41 65, 1991. 
REDAELLI, L.R.; BECKER, M.; ROMANOWSKI, H.P. Changes in the internal reproductive organs and fat body levels as diapause indicators in Oryzophagus oryzae (Coleoptera: Curculionidae). Revista Brasileira de Biologia, v.55, n.4, p.737-744, 1995.

RUSSEL, M.P. Influence of rice variety on oviposition and development of the rice weevil, Sitophilus oryzae, Annals of the Entological Society of America, v.61, p.1335-2879, 1968.

SALIM, M.; SAXENA, R.C. Nutritional stresses and varietal resistance in rice: effects on whitebacked planthopper. Crop Science, v.31, n.3, p. 797-805, 1991.

SALIM, M.; SAXENA, R.C. Iron, silica and aluminum stress and varietal resistance in rice: Effects on white backed plant hopper. Crop Science, v.32, p. 212-219, 1992.

SAMALO, A.P.; NYAK, S.K.; LENKA, D. et al.. Interaction of fertilizers and rice genotypes on yellow stem borer in deepwater rice. Madras Agricultural Journal, v.78, n.4, p. 86-87, 1991.

SAVANT, A. S.; PATIL, V. H.; SAVANT, N. K. Rice hull ash applied to seedbed reduces deadhearts in transplanted rice. International Rice Research Notes, v. 19, n. 4, p. 21-22, 1994.

SAVANT, N.K.; SNYDER, G.H.; DATNOFF, L.E. Silicon management and sustainable rice production. Advances in Agronomy, v. 58, p. 151-199, 1997. 
SHIGEMATSU, Y.; MUROFUSHI, N.; ITO, K. et al. Sterols and asparagine in the rice plant, endogenous factors related to resistance against the brown planthopper (Nilaparvata lugens). Agricultural Biology and Chemistry, v.46, n.11, p.2877-2879, 1982.

SILVA, D.J. Análise de alimentos (métodos químicos e biológicos). 2.ed. Viçosa: UFV, 1990. 165p.

SMITH, C.M.; ROBINSON, J.F. Evaluation of rice cultivars grown in North America for resistance to the rice water weevil. Environmental Entomology, v.11, p.334-336, 1982.

SUBAMANIAN, S.; GOPALASWAMY, A. Effect of silicate materials in rice crop pests. International Rice Research Newsletter, v.13, n.3, p.32, 1988.

SUBBARAO, D.V.; PERRAJU, A. Resistance in some rice strains to first-instar larvae of Tryporyza incertulas (Walker) in relation to plant nutrients and anatomical structure of the plants. International Rice Research Newsletter, v.1, n.1, p.14-15, 1976.

SUDHAKAR, G.K.; SINGH, R.; MISHRA, S.B. Susceptibility of rice varieties of different durations to rice leaf folder, Cnphalocrocis medinalis Guen. Evaluated under varied land situations. Journal of Entomological Resea rch, v.15, n.2, p. 79-87, 1991.

SUJATHA, G.; REDDY, G.P.V.; MURTHY, M.M.K. Effect of certain biochimical factors on expression of resistance of rice varieties to brown plant hopper (Nilaparvata lugens Stal). Journal Research Apau, v. 15, p. 124-128, 1987. 
STOUT, M.J.; RICE, W.C.; BOLLICH, P.K. et al. Impact of fertilization rate on rice resistance and tolerance to the rice water weevil: a preliminary report. In: RICE RESEARCH STATION. Agricultural Center. Annual research report 90 th. Crowley: Louisiana State University, 1998. p. 496-499.

TEDESCO, M.J.; VOLKWEISS, S.J.; BOHNEN, H. Análise de solo, plantas e outros materiais. Porto Alegre: UFRGS, 1985. 118p. (UFRGS. Boletin Técnico de Solos,5).

TERRES, A.L.S.; MACHADO, M.O.; FAGUNDES, P.R.R. et al. Melhoramento genético de arroz irrigado na Embrapa Clima Temperado: 10. BRS Firmeza e BRS Atalanta, novas cultivares para a orizicultura gaúcha. In: CONGRESSO BRASILEIRO DE ARROZ IRRIGADO, 1.; REUNIÃO DA CULTURA DO ARROZ IRRIGADO, 23., Pelotas, 1999. Anais. Pelotas: Embrapa Clima Temperado, 1999. p. 158-161.

TSUZUKI, H.; ASAYAMA, T.; AMANO, T. et al. Studies on biology and control of the newly invaded insect rice water weevil Lissorhoptrus oryzophilus Kushel. Research Bulletin of the Aichi-Ken Agricultural Research Center, n.15, p.1-135, 1984.

TUGWELL, N.P.; STEPHEN, F.M. Rice water weevil seasonal abundance, economic levels, and sequential sampling plants. Fayetteville: Agricultural Experiment Station, 1981. 16p. (Bulletin, 849).

VENDRAMIM, J.D.; TAPIA, D.M.T.; REIS, M.T. Influência de defeitos na casca de arroz sobre a infestação de Sitophilus zeamais Mots., e Sitophilus oryzae (L., 1763) (Col. Curculionidae). Ecosistema, v.14, p.125-131, 1989. 
UKWUNGWU, M.N.; ODEBIYI, J.A. Incidence of the Chilo zacconius Bleszynsky on some rice varieties in relation to plant characters. Insect Science Aplication, v.6, n.6, p.653-656, 1985.

WINSLOW, M.D. Silicon, disease resistance and yield of rice genotypes under uplant cultural conditions. Crop Science, v. 32, p. 1208-1213, 1992.

WOODHEAD, S; PADCHAM, D.E. The effect of plant surface characteristics on resistance of rice to the brown planthopper, Nilaparvata lugens. Entomologia Experimental \& Applicata, v.47, p.15-22, 1988.

YOSHIDA, S. The physiology of silicon in rice. Taipei: Food and Fertilization Technology Center, 1975. (FFTC. Technil Bulletin, 25).

YOSHIDA, S.; ONSHI, Y.; KITAGISHI, K. The chemical nature of silicon in rice plant. Soil and Plant Food, v.5, p.23-27, 1979.

ZHAO, S.X.; WU, Z.F.; WU, G. et al. The effects of antibiotic resistance of rice varieties on the esterase contents in brown planthopper. Acta Phytophylacica Sinica, v.20, n.3, p.193-198, 1993.

ZONTA, E.P.; SILVEIRA, P.; MACHADO, A.A. Sistema de análise estatística (SANEST). Instituto de Física e Matemática, UFPel, Pelotas, 399p. 1986. 